\title{
Empirical models for estimating monthly global solar radiation: a most comprehensive review and comparative case study in China
}

Article

Accepted Version

Creative Commons: Attribution-Noncommercial-No Derivative Works 4.0

Chen, J.-L., He, L., Yang, H., Ma, M., Chen, Q., Wu, S.-j. and Xiao, Z.-I. (2019) Empirical models for estimating monthly global solar radiation: a most comprehensive review and comparative case study in China. Renewable and Sustainable Energy Reviews, 108. pp. 91-111. ISSN 1364-0321 doi: https://doi.org/10.1016/j.rser.2019.03.033 Available at https://centaur.reading.ac.uk/83134/

It is advisable to refer to the publisher's version if you intend to cite from the work. See Guidance on citing.

To link to this article DOI: http://dx.doi.org/10.1016/j.rser.2019.03.033

Publisher: Elsevier

All outputs in CentAUR are protected by Intellectual Property Rights law, including copyright law. Copyright and IPR is retained by the creators or other copyright holders. Terms and conditions for use of this material are defined in the End User Agreement. 


\section{www.reading.ac.uk/centaur}

\section{CentAUR}

Central Archive at the University of Reading

Reading's research outputs online 


\title{
Empirical models for estimating monthly global solar radiation: A most comprehensive review and comparative case study in China
}

Ji-Long Chen ${ }^{\mathrm{a}}$, Lei He ${ }^{\mathrm{b}}$, Hong Yang ${ }^{\mathrm{c}}$, Maohua Ma ${ }^{\mathrm{a}}$, Qiao Chen ${ }^{\mathrm{a}}$, Sheng-Jun $\mathrm{Wu}^{\mathrm{a}}$, Zuo-lin $\mathrm{Xiao}^{\mathrm{d}}$

a. Key Laboratory on Water Environment of Reservoir Watershed, Chongqing Institute of Green and Intelligent Technology, Chinese Academy of Sciences, Chongqing 401122, China

b. Key Laboratory of Poyang Lake Wetland and Watershed Research, Ministry of Education, Nanchang 330000, China

c. Department of Geography and Environmental Science, University of Reading, Whiteknights, Reading RG6 6AB, UK

d. The Key Laboratory of GIS Application Research, Chongqing Normal University, Chongqing 401331, China

\begin{abstract}
Global solar radiation is a core component of scientific research and engineering application across a broad spectrum. However, its measurement is limited by a small number of observation stations due to the technical and financial restricts. Estimating solar radiation with the meteorological variables using empirical models is of benefit to obtain solar radiation data at global scale. Yet, there are various options of available empirical models to select the most suitable one. This study conducted a most comprehensive collection and review of empirical models employing the commonly measured meteorological variables and geographic factors. A total of 294 different types of empirical models were collected and classified into 37 groups according to input attributes. Such collection built an empirical model library providing an overall overview of the developed emperical models in literatures. Furthermore, the collected models were calibrated and evaluated at three meteorological stations in the Three Gorges Reservoir area in China. This study suggests that these model-comparing processes can assist the governments, scientists and engineers in tailoring the most fitted model for specific applications and in particular areas.
\end{abstract}

Keywords: Global solar radiation, empirical models, meteorological variables, comparisons, Three Gorges Reservoir 


\begin{tabular}{|c|c|c|c|}
\hline \multicolumn{4}{|c|}{ Nomenclature } \\
\hline$\varphi$ & Latitude of the site (rad) & Tmin & Minimum air temperature $\left({ }^{\circ} \mathrm{C}\right)$ \\
\hline $\mathrm{K} \varphi$ & Altitude factor & $\operatorname{Tmax}$ & Maximum air temperature $\left({ }^{\circ} \mathrm{C}\right)$ \\
\hline$\lambda$ & Longitude of the site (rad) & $\Delta \mathrm{T}$ & Difference between maximum and \\
\hline $\mathrm{Z}$ & Altitude of the site (m) & & minimum air temperatures $\left({ }^{\circ} \mathrm{C}\right)$ \\
\hline$\delta$ & Declination angle (rad) & $\mathrm{Rh}$ & Relative humidity (\%) \\
\hline $\mathrm{n}$ & The day of year & $\mathrm{P}$ & Precipitation $(\mathrm{mm})$ \\
\hline \multirow[t]{2}{*}{$\mathrm{L}$} & Mahmood-Hubbard transmissibility & $\mathrm{Pa}$ & The transformed precipitation data \\
\hline & coefficient & Ap & Atmospheric pressure (Kpa) \\
\hline Rs & Global solar radiation $\left(\mathrm{MJ} \mathrm{m}^{-2}\right)$ & Aps & Standard sea level atmospheric \\
\hline \multirow[t]{2}{*}{$\mathrm{Ra}$} & Extraterrestrial solar radiation (MJ & & pressure $(\mathrm{KPa})$ \\
\hline & $\left.\mathrm{m}^{-2}\right)$ & $\mathrm{Vp}$ & Vapor pressure (Kpa) \\
\hline$S$ & Sunshine duration $(\mathrm{h})$ & Es & Saturation vapor pressure (Kpa) \\
\hline $\mathrm{S}_{0}$ & Potential sunshine duration (h) & $\mathrm{D}$ & Vapor pressure deficit (Kpa) \\
\hline \multirow[t]{2}{*}{$\mathrm{Sn}$} & Adjusted potential sunshine & $\mathrm{Wv}$ & wind velocity $(\mathrm{m} / \mathrm{s})$ \\
\hline & $\begin{array}{l}\text { duration taking into account the } \\
\text { natural horizon (h) }\end{array}$ & $\mathrm{Wa}$ & $\begin{array}{l}\text { Atmospheric precipitable water } \\
\text { vapor per unit volume of air }(\mathrm{cm})\end{array}$ \\
\hline $\mathrm{S}_{04}$ & $\begin{array}{l}4^{\mathrm{o}} \text { corrected potential sunshine } \\
\text { duration }(\mathrm{h})\end{array}$ & $\begin{array}{l}\mathrm{a}, \mathrm{b}_{\mathrm{i}}, \mathrm{c}_{\mathrm{i}} \\
\mathrm{d}_{\mathrm{i}}, \mathrm{e}_{\mathrm{i}}, \mathrm{f}_{\mathrm{i}}\end{array}$ & Empirical coefficients \\
\hline $\mathrm{T}$ & Average air temperature $\left({ }^{\circ} \mathrm{C}\right)$ & and $g_{i}$ & \\
\hline
\end{tabular}




\section{Introduction}

Global solar radiation is the principal and fundamental energy for many Earth' surface and atmospheric processes such as plant photosynthesis and evapotranspiration [1-3]. It regulates the Earth' temperature, while spatiotemporal variation of the radiation is the primary driver for global climate change [4]. Moreover, due to the global issues such as global warming [5] and environmental pollution [6] caused by the consumption of the fossil fuels [7-8], solar radiation has attracted increasing attentions as a clean, environmental-friendly, and inexhaustible energy [9-11], particularly in China. In the process of building agricultural [12], environmental [13], hydrological and ecological models [14], the global solar radiation is a critical variable. It is also crucial for designing solar furnaces [15], concentrating solar collectors [16] and sizing photovoltaic cells [17]. However, measurement of solar radiation is limited by a limited number of observation stations mainly due to the financial and technical limitations [18-20]. Lack of sufficient solar radiation data has been reported worldwide [21-23]. On the contrary, sunshine duration, air temperatures and other common meteorological variables are routinely measured at most stations [24-26]. Therefore, great efforts have been made to estimate global solar radiation from meteorological variables by means of empirical models [27-29].

Estimation of global solar radiation was initiated by Angstrom [30] and Prescott [31] who introduced the Angstrom-Prescott (A-P) model. This model was widely validated and evaluated at many locations around the world. Besharat et al [2] compared the accuracy of many A-P equations with different empirical coefficients in Iran. Giwa et al [8] validated the A-P model in Nigeria. Chukwujindu [10] evaluated the accuracy of A-P equations in Africa. Yao et al [32] evaluated the performance of A-P model in China. Several revised versions of the A-P model have been suggested by changing the structure of A-P model from linear to quadratic [33], cubic [34], exponential [35] or logarithmic [36]. The comparative studies indicated that some revised versions performed similarly to the A-P model [37]. Mohammadi et al [38] evaluated the accuracy of linear, quadratic, cubic and exponential models in Iran, and they found that these models had similar performances. Teke and Yildirim [39] estimated solar radiation using linear, quadratic and cubic models, and the evaluations showed that these models performed similarly in Eastern Mediterranean Region. Meher et al [40] compared the linear, quadratic, cubic, logarithmic and exponential models, and reported the insignificant difference among these models. Consequently, many modifications to the A-P model have been made by incorporating additional meteorological variables. Lee [41] and Saffaripour et al [42] incorporated air temperature and modified the A-P model. Bakirci Kadir [43] introduced relative humidity in an additive form and suggested a new form. Liu et al [44] revised the A-P using atmospheric pressure. Chen and $\mathrm{Li}$ [20] modified the A-P model using precipitation. Fan et al [45] introduced the combination of air temperature and precipitation to the A-P model. Okonkwo and Nwokoye [46] modified the A-P model using air temperature, relative humidity and precipitation.

Sunshine duration models are often limited due to the unavailability of sunshine duration data [47-48]. To solve this problem, Hargreaves and Samani [49] proposed a simple model (H-S model) using air temperature range (difference between minimum and maximum air temperatures). This model was widely modified by others [50]. Chen and Li [20] and Hassan 
et al [51] introduced the effect of precipitation to modify the H-S model. Li et al [52] and Korachagaon and Bapat [53] revised the H-S model using relative humidity. Chen et al [54] modified the H-S model using atmospheric pressure, relative humidity and precipitation. Bristow and Campbell [55] developed a model (B-C model) as exponential function of temperature range. Many modifications to the $\mathrm{B}-\mathrm{C}$ model have subsequently been made, and most modifications are centered on the adjustment of the coefficients. However, comparative studies suggested that such modifications yielded little improvement [56]. Although the $\mathrm{H}-\mathrm{S}$ and B-C models are empirically derived, they were based on the theoretical assumption that temperature range is mainly derived by the radiation [57]. Many validations showed that the performances of $\mathrm{H}-\mathrm{S}$ and $\mathrm{B}-\mathrm{C}$ models and their modifications varied greatly from regions to regions, and the accuracies were affected by the geographic location and local climates [56].

In addition to the two categories of the models reviewed above, some scholars have explored the estimation of solar radiation using relative humidity, precipitation and atmospheric pressure which are also easily and widely available. Kolebaje et al [58] presented a power model using relative humidity for West Africa. Adaramola [59] developed a linear model using precipitation. Kamal [60] obtained a linear model using atmospheric pressure. Akpabio et al [61] proposed a multivariate linear model using relative humidity and precipitation in Nigeria.

Huge efforts have been made to estimate solar radiation with empirical model. However, it is still a challenging task to develop better accuracy models due to the complex process of radiation [62]. Because long-term meteorological data are easily available, it is preferred to select a suitable model for particular regions instead of developing new models. However, the number of the empirical models is so large that it is difficult to choose the most appropriate one [5]. Thus, several studies have reviewed the empirical models from literatures. Yildirim et al [1] investigated the efficiency of 10 different models for estimating solar radiation in Turkey. Besharat et al [2] comprehensively reviewed 78 empirical models for the selection of most accurate one for Iran. Despotovic et al [5] evaluated 101 sunshine duration models using long term meteorological data throughout the world. Bayrakci et al [9] compared 105 empirical models from literatures and 7 new models and proposed the most appropriate one for Turkey. Chukwujindu [10] reviewed 65 empirical models which were classified into six categories according to the input meteorological variables. Yildirim et al [13] presented a quantitative collection of empirical models based on different meteorological variables and suggested the most accurate model in Turkey. Mohamed et al [21] evaluated 11 different empirical models and introduced the best one for Africa. Zhang et al [22] conducted a critical literature review and compared the models for estimation of solar radiation at different scales. Yao et al [32] evaluated the accuracy of 118 equations at Shanghai in China. Bakirci [63] reviewed 60 different solar radiation models in the literature. Evrendilek and Ertekin [64] compared 78 different empirical models and selected the most robust one for Turkey. Later, Sonmete et al [65] examined 147 solar radiation models and proposed the best one for Turkey.

In these reviews, many equations have the same formulas just with different coefficients. Besharat et al [2] reviewed 64 equations using sunshine duration. These equations were classified into 35 models. Chukwujindu [10] collected 732 equations which can be classified into 65 models. The 105 sunshine duration models reviewed by Bayrakci et al [9] can be classified into 12 models according to the mathematical expression. Similarly, the 101 models 
reviewed by Despotovic et al [5] can be classified into 20 models. The 118 equations compared by Yao et al [32] can be classified into 14 models. However, after a most comprehensive investigation of a large number of literatures, we collected 294 different empirical models which can be classified into 37 groups according to the input variables. This indicates that those reviews only presented a small portion of the empirical models and further suggests a more comprehensive study.

Therefore, the main objective of this study is to conduct a most comprehensive collection and review of the empirical models based on the commonly measured meteorological variables including sunshine duration, average temperature, minimum temperature, maximum temperature, relative humidity, precipitation, atmospheric pressure, vapor pressure, and wind velocity. In addition, geographic factors including the latitude, longitude, and altitude of the site, solar declination angle, and the day of the year are easily available. Thus, models employing these geographic factors are also presented in this study. Such comprehensive review would build a model library providing an overview of the developed empirical models in literatures. Furthermore, in order to compare the performances of the collected models, these models are validated and evaluated at three meteorological stations in Three Gorges Reservoir Area (TGRA), China. This would be helpful for researchers and engineers to tailor the most fitted model for applications in agriculture, climate, ecology and energy studies.

\section{Materials and method}

\subsection{Case study area}

TGRA (Fig.1) is located at the upstream of the Yangtze River in China, to the east of Sichuan Basin, to the north of Daba Mountain, and bordering the western Middle-Lower Yangtze river plain. It stretches along the Yangtze River from Jiangjin county in Chongqing municipality to Yichang city in Hubei province, with the area of $5.8 \times 10^{4} \mathrm{~km}^{2}$ [66]. The geography is complex and the elevation generally decreases from northeast to southwest [67]. The region is dominated by mountainous and hilly areas [68]. TGRA is located in the transfer zone between the northern temperate zone and the subtropical zone. The climate of TGRA is subtropical monsoon climate which is characterized by four distinct seasons with a hot, humid summer, and mild to cool winter [24]. Annual mean temperature is between $16.5^{\circ} \mathrm{C}$ and $19^{\circ} \mathrm{C}$, and annual precipitation is about $1100 \mathrm{~mm} 69$ [66].

\subsection{Sites and data collection}

Three stations with available records of global solar radiation and meteorological variables were used in this work (Fig.1). The observed meteorological variables include sunshine duration, maximum temperature, minimum temperature, average temperature, relative humidity, precipitation, atmospheric pressure, vapor pressure, and wind velocity. Chongqing station $\left(29^{\circ} 35^{\prime} \mathrm{N}\right.$ and $\left.106^{\circ} 28^{\prime} \mathrm{E}\right)$ lies at $259.1 \mathrm{~m}$ above sea level located in the upper section of TGRA. Yichang station $\left(30^{\circ} 42^{\prime} \mathrm{N}\right.$ and $\left.111^{\circ} 18^{\prime} \mathrm{E}\right)$ is located at about $30 \mathrm{~km}$ near from the Three Gorges Dam (TGD), with the altitude of $133.1 \mathrm{~m}$. Wanzhou station $\left(30^{\circ} 46^{\prime} \mathrm{N}\right.$ and $108^{\circ}$ $\left.24^{\prime} \mathrm{E}\right)$ lies at $186.7 \mathrm{~m}$ above sea level located in the middle section of TGRA.

The meteorological observations started from 1961 at the three sites, while the measurements of global solar radiation at Wanzhou are missing since 1991 due to the technical failure [70-71]. Monthly meteorological data for Chongqing and Yichang 
(1977-2016) and Wanzhou (1961-1990) were obtained from the Chinese National Meteorological Information Center (NMIC), China Meteorological Administration (CMA). Global solar radiation $\left(\mathrm{MJ} \mathrm{m}^{-2}\right.$ ) was measured by Pyranometer [72-73]. Sunshine duration (h) was measured by Jordan sunshine recorder. Air temperatures $\left({ }^{\circ} \mathrm{C}\right)$ was measured by mercury and alcohol thermometers. Atmospheric pressure (Kpa) was measured by mercury barometer. Vapor pressure (Kpa) was measured by adjustable cistern barometer. Relative humidity(\%) was measured by aspirated psychrometer at $2 \mathrm{~m}$ height [74-75]. Wind velocity $(\mathrm{m} / \mathrm{s})$ was measured by EL wind electric anemometer at $10 \mathrm{~m}$ height, which was transformed to speed at $2 \mathrm{~m}$ height by a logarithmic model proposed by FAO56 [76]. All the instruments were calibrated periodically and all the meteorological variables were measured following the standardized procedures recommended by the WMO [73].

\subsection{Data check and datasets split}

The quality controls were carefully conducted by the CMA, while meteorological measurements can still contain errors due to the occasional voltage instability and equipment errors [77]. Previous studies pointed out that quality control of meteorological data provided by NMIC should be conducted before the usage of these data [78]. Consequently, we further checked the data following the criterions from the quality control scheme presented by Feng et al [79] and Tang et al [80]. First, the records with missing data which were replaced by 32766 were removed. Second, global solar radiations exceeding extra-terrestrial radiation were excluded from the dataset. Then, sunshine duration larger than potential sunshine duration were also deleted. Third, minimum air temperature larger than maximum air temperature were removed. Lastly, the data with evident systematic and operational errors were removed. More details can be found in Feng et al [79] and Tang et al [80].

Two sub-datasets were subsequently built for each station, and the first $75 \%$ of the records were used for modelling and the remaining $25 \%$ for evaluation. 30 -years long modelling data (1977-2006) were used for Chongqing and Yichang sites, and this is because that 30-years long time series is enough to filter out the inter-annual variation or anomalies according to WMO. Thus, the model describing the relationship between solar radiation and meteorological variables based on the 30-years long data would exhibit a higher degree of reliability and confidence. While 22-years long modelling data (1961-1982) were used for Wanzhou site.

\subsection{Description of observed meteorological data}

Distributions of the monthly meteorological variables of the three stations are presented in Fig.2. Monthly daily solar radiation varied between $4.25 \mathrm{MJ} \mathrm{m}^{-2}$ in December and $16.03 \mathrm{MJ}$ $\mathrm{m}^{-2}$ in July, with the average of $9.7 \mathrm{MJ} \mathrm{m}^{-2}$. Monthly daily sunshine duration varied between $1.46 \mathrm{~h}$ in January and $6.27 \mathrm{~h}$ in August, with the average of 3.46h (Fig.2a). Maximum, minimum and average temperatures, which ranged from 9.74 to $33.16^{\circ} \mathrm{C}$, from 4.14 to $24.54^{\circ} \mathrm{C}$ and from 6.51 to $28.17^{\circ} \mathrm{C}$, respectively, show similar change patterns with the warmest month in July and the coldest month in January (Fig.2b). Vapor pressure varied between $0.78 \mathrm{kPa}$ in January and $2.93 \mathrm{kPa}$ in July, which was generally opposite to that of atmospheric pressure with the minimum of $97.9 \mathrm{kPa}$ in July and the maximum of $100.09 \mathrm{kPa}$ in December (Fig.2c). Monthly precipitation varied between $18.72 \mathrm{~cm}$ and $197.32 \mathrm{~cm}$, with the maximum in July and the minimum in January (Fig.2d). Relative humidity ranged between $75.98 \%$ and $81.66 \%$, and wind velocity ranged between $0.9 \mathrm{~m} / \mathrm{s}$ and $1.24 \mathrm{~m} / \mathrm{s}$ (Fig.2e), without 
clear seasonal pattern.

2.5 Statistical evaluation and validation

The accuracy and performances of the collected models were evaluated and compared using root mean square error (RMSE) and relative root mean square error (RRMSE) (\%). These indicators are widely used to evaluate model performances and thus provide a benchmark to compare models from literatures. Lower values of RMSE and RRMSE indicate a better performance. They were calculated from the following equations:

$$
\begin{array}{r}
R M S E=\sqrt{\frac{\sum_{i=1}^{n}\left(y_{i, m}-y_{i, p}\right)^{2}}{n}} \\
\operatorname{RRMSE}(\%)=100 \sqrt{\frac{\sum_{i=1}^{n}\left(y_{i, m}-y_{i, p}\right)^{2}}{n y_{i, m}}}
\end{array}
$$

Where $n, y_{i, m}$, and $y_{i, p}$ represent the number of testing data, the measured value and the estimated value, respectively.

\section{Model review}

A large number of empirical models have been developed for estimation of global solar radiation. The first attempt was conducted by Angstrom [30] who suggested a linear relationship between the ratio of global solar radiation to the corresponding value on a clear day and sunshine fraction. Prescott [31] modified the Angstrom model by replacing the solar radiation on a clear day with the extraterrestrial radiation. The extraterrestrial radiation and potential sunshine duration were calculated using the equations detailed by Allen et al [76].

$$
\begin{gathered}
R a=37.6 d(\omega \sin \sin \delta+\cos \cos \delta \sin \omega) \\
d=1+0.033 \cos \left(\frac{2 \pi}{365} n\right) \\
\delta=0.4093 \sin \left(\frac{2 \pi}{365} n-1.39\right) \\
\omega=\arccos (-\tan \varphi \tan \delta) \\
\text { So }=24 \omega / \pi
\end{gathered}
$$

where $d$ is the relative distance between the sun and the earth, $\omega$ is sunset hour angle (rad), $\varphi$ is latitude ( $\mathrm{rad}), \delta$ is solar declination angle ( $\mathrm{rad})$, and $n$ is the number of the day of year starting from the first of January.

After a comprehensive investigation and review of the literatures, a total of 294 empirical models using different combinations of the meteorological variables and geographic factors were found and presented in Table 1. Meteorological variables employed in the models include sunshine duration, average temperature, maximum temperature, minimum temperature, relative humidity, precipitation, atmospheric pressure, vapor pressure and wind velocity. These variables are routinely measured by CMA and datasets are easily available from the Chinese NMIC (http://data.cma.cn). Besides, geographic factors including the 
latitude, longitude, and altitude of the site, solar declination angle, and the day of the year are also easily available. These models were classified into 37 groups according to the input variables.

\subsection{Group 1: sunshine duration (S) models}

Sunshine duration models are the most widely used empirical relationships as the result of their promising performances. $28 \mathrm{~S}$ models were collected from literatures and presented in Table 1, and most of these models related the clearness index (ratio of global solar radiation to extraterrestrial radiation) to sunshine fraction. The most well-known one in this group is the A-P model. Many revised versions of the A-P model have been developed by changing the structure of A-P model from linear to quadratic [33], cubic [34], high order [81], exponential [35], logarithmic [36], trigonometric [82] and hybrid forms [83-84]. These models were widely calibrated and evaluated at many locations around the world.

3.2 Group 2: sunshine duration - temperature (ST) models

21 ST models were found in literatures, and most of them were modifications to the A-P model by introducing average temperature [85], maximum temperature [86], minimum temperature [85], temperature range [20] and the combinations of temperatures $[20,85]$. Some other models were proposed as the exponential [87], quadratic and cubic [88] or hybird functions [89] of the ratio of temperature range to potential sunshine duration.

\subsection{Group 3: sunshine duration - relative humidity (SR) models}

In this model group, sunshine duration and relative humidity were incorporated with solar radiation or clearness index in the forms of linear [42], quadratic [43] and power [90] functions.

3.4 Group 4: sunshine duration - precipitation (SP) models

Chen and $\mathrm{Li}$ [20] introduced precipitation in an additive form to A-P model and presented a SP model in China.

3.5 Group 5: sunshine duration - pressure (SPr) models

Models in this group related the clearness index or solar radiation to the combinations of sunshine duration, atmospheric pressure and vapor pressure [44, 91].

3.6 Group 6: sunshine duration - geographic factors (SG) models

The empirical coefficients of sunshine duration models varied from one site to another. Thus, geographical factors were included to account for the effect of geographical location, and to modify the relationship between solar radiation and meteorological variables. Most of the models in this group are modifications to sunshine duration models by introducing geographical factors in linear [92-94], trigonometric [95] and hyprid function [93-94]. Because the latitude, longitude and altitude are constants for a specific site, they were employed to develop universal models using the pooled data from all the studied sites. A total of 30 SG models were collected and presented in Table 1.

\subsection{Group 7: sunshine duration - temperature - relative humidity (STR) models}

17 STR models were collected from literatures. Models in this group are modifications to sunshine duration model by introducing the linear [96-97] and nonlinear [98] combinations of temperatures and relative humidity, and most of the modifications are based on the A-P model.

3.8 Group 8: sunshine duration - temperature - precipitation (STP) models

In this group, sunshine duration, temperatures and precipitation were incorporated with 
clearness index for estimation of solar radiation in the forms of linear [20,46], quadratic and cubic [99] and hybird [45] functions.

3.9 Group 9: sunshine duration - temperature - pressure (STPr) models

In this group, clearness index or solar radiation was correlated with the combinations of sunshine duration, temperature and pressure in the forms of linear [20], power [54] and hybrid [44] functions.

3.10 Group 10: sunshine duration - relative humidity - precipitation (SRP) models

Saffaripour et al [42] developed a SRP model for estimation of solar radiation using extra-terrestrial solar radiation, sunshine fraction, relative humidity and precipitation.

3.11 Group 11: sunshine duration - temperature - geographic factors (STG) models

Models in this group related solar radiation to the combinations of sunshine fraction, temperature and geographic factors in the form of hybrid function [99].

3.12 Group 12: sunshine duration - temperature - relative humidity - precipitation (STRP) models

In this group, sunshine duration, temperatures, relative humidity and precipitation were incorporated with clearness index for estimation of solar radiation [100].

3.13 Group 13: sunshine duration - temperature - relative humidity - pressure (STRPr) models

Models in this group are modifications to the A-P model by introducing the linear combinations of temperatures, relative humidity and pressure as an additive form [25, 101].

3.14 Group 14: sunshine duration - temperature - precipitation - pressure (STPPr) models

Chen et al [54] presented a hybrid model for estimation of solar radiation using extra-terrestrial solar radiation, sunshine fraction, temperature range, precipitation and vapor pressure deficit.

3.15 Group 15: sunshine duration - temperature - relative humidity - wind (STRW) models

Adeala et al [102] modified the A-P model by introducing the linear combinations of average temperature, relative humidity and wind velocity.

3.16 Group 16: sunshine duration - temperature - relative humidity - geographic factors (STRG) models

In this group, geographic factors were included to modify the relationship between solar radiation and sunshine duration, temperature, and relative humidity. 13 STRG models were collected from literatures and presented in Table 1, and most of them are modifications to STR model by introducing geographical factors in trigonometric [99] and hyprid functions [103].

3.17 Group 17: sunshine duration - temperature - precipitation - geographic factors (STPG) models

Chen et al [99] modified the A-P model using the linear combinations of air temperature, precipitation, latitude, longitude and altitude and suggested 5 STPG models.

3.18 Group 18: sunshine duration - temperature - relative humidity - precipitation - pressure (STRPPr) models

In this group, sunshine duration, temperatures, relative humidity, precipitation and pressure were incorporated with clearness index or solar radiation in the form of hybrid function [45].

3.19 Group 19: sunshine duration - temperature - relative humidity - precipitation - wind (STRPW) models

Ouali and Alkama [104] modified the A-P model by introducing the temperature, relative 
humidity, precipitation and wind velocity and presented a multivariate linear and a hybrid function.

3.20 Group 20: sunshine duration - temperature - relative humidity - precipitation geographic factors (STRPG) models

In this group, declination angle and the day of year were used to modify the relationship between solar radiation and sunshine duration, temperature, relative humidity, and precipitation [105].

3.21 Group 21: temperature (T) models

Numerous evaluations showed that the sunshine-based models (sunshine duration models and their modifications) are generally more accurate than temperature-based models (temperature models and their modifications) [2, 21, 47]. However, the sunshine-based models are often limited since sunshine duration data are often not accessible [47-48]. On the contrary, air temperatures data are easily and widely available. In this context, Hargreaves and Samani [49] proposed the H-S model using air temperature range. Using the same data input as by Hargreaves and Samani [49], Bristow and Campbell [55] suggested the B-C model. Both models were widely calibrated and evaluated, and many revised versions of $\mathrm{H}-\mathrm{S}$ and B-C models were subsequently developed and validated at many places around the world. A total of 64 temperatures models were collected and presented in Table 1.

\subsection{Group 22: temperature - relative humidity (TR) models}

19 TR models were collected from literatures. In this group, relative humidity was introduced as an additive form [20, 58] and multiplicative form [52, 106] to modify the correlation between solar radiation and air temperatures.

3.23 Group 23: temperature - precipitation (TP) models

In this group, temperature and precipitation were incorporated with clearness index or solar radiation for estimating global solar radiation [56, 107].

3.24 Group 24: temperature-pressure (TPr) models

Models in this group related the clearness index or solar radiation to the combinations of temperature, atmospheric pressure and vapor pressure [20].

3.25 Group 25: temperature - geographic factors (TG) models

In this group, declination angle, the day of year and the altitude were used to modify the correlation between solar radiation and temperatures [105].

3.26 Group 26: temperature - relative humidity - precipitation (TRP) models

In this group, global solar radiation was correlated with the combinations of temperature, relative humidity and precipitation in the forms of quadratic [96], power [108] and hybrid functions [56].

3.27 Group 27: temperature - relative humidity - pressure (TRPr) models

Chen and Li [20] modified the H-S model and Li model [107] by introducing the relative humidity, atmospheric pressure and vapor pressure in an additive form.

3.28 Group 28: temperature - relative humidity - geographic factors (TRG) models

In this group, declination angle and the day of year were included to modify the relationship between solar radiation with temperatures and relative humidity [106].

3.29 Group 29: temperature - precipitation - pressure (TPPr) models

Chen et al [54] modified the H-S model using precipitation and vapor pressure and suggested 4 TPPr models for estimation of solar radiation in China. 
3.30 Group 30: temperature - precipitation - wind (TPW) models

Richardson and Reddy [109] proposed an equation to estimate solar radiation using temperature range, precipitation and wind velocity.

3.31 Group 31: temperature - precipitation - geographic factors (TPG) models

In this group, temperature, precipitation and geographic factors were incorporated with clearness index or solar radiation for the estimation of global solar radiation [99].

3.32 Group 32: temperature - relative humidity - precipitation - geographic factors (TRPG) models

Meza and Yebra [110] presented a hybrid function to estimate global solar radiation using temperature range, relative humidity, precipitation and the day of year.

3.33 Group 33: relative humidity (R) models

In this group, clearness index or global solar radiation was correlated with relative humidity in the forms of linear [111], exponential [90], power [58] and high order functions [53].

3.34 Group 34: Precipitation (P) model

Adaramola [59] developed a simple equation to estimate solar radiation using precipitation. 3.35 Group 35: relative humidity - precipitation (RP) model

Akpabio et al [61] proposed a multivariate linear equation using relative humidity, precipitation and extraterrestrial solar radiation for estimation of global solar radiation.

3.36 Group 36: precipitation - geographic factors (PG) model

Reddy [112] developed a model to estimate solar radiation using precipitation and latitude. 3.37 Group 37: pressure (Pr) model

Kamal Skeiker [60] developed a linear equation to estimate solar radiation using extraterrestrial solar radiation and atmospheric pressure.

\section{Results and discussion}

The collected models were calibrated and evaluated at three stations in the TGRA in China. The performances are presented in Table 2 and Figs.3-10. The calibrated coefficients of the models are presented in Supplementary Data.

Among the sunshine duration models (Fig.3), the model S15 had the lowest RMSE of $1.0863 \mathrm{MJ} \mathrm{m}^{-2}$ and RRMSE of $12.16 \%$ at Chongqing, the model $\mathrm{S} 28$ performed best at Wanzhou, with the RMSE of $0.7759 \mathrm{MJ} \mathrm{m}^{-2}$ and RRMSE of $8.47 \%$, and the model $\mathrm{S} 16$ was the most accuracy one at Yichang, with the RMSE of $1.3733 \mathrm{MJ} \mathrm{m}^{-2}$ and RRMSE of $13.01 \%$. Models S1-S3 showed much higher error indicators (RMSE and RRMSE) than other models, the poor performances of these models were also reported by other literatures [167-168]. Models S4-S7 had similar error indicators, which were slightly higher than those of models S8-S28 (except model S12) that also gave similar performances at the same site for Chongqing and Wanzhou. Except models S12 and S15-16, models S4-S28 also presented similar error indicators at Yichang. These results indicate that revisions of the A-P model by changing the structure from linear to nonlinear forms were generally not effective and yielded little or no improvement, which is similar with the previous studies [37-40, 168-171].

In group 2 (Fig.4), models ST11-15 and ST20-21 showed higher estimation errors than other models. Models ST16-19 performed similarly at the same station. Models ST2-10 (except ST8) also presented similar error indicators to models ST16-19 at Wanzhou. Models ST10, ST19 and ST9 performed best at Chongqing, Wanzhou and Yichang, with the RMSE of 
$0.8951 \mathrm{MJ} \mathrm{m}^{-2}, 0.7898 \mathrm{MJ} \mathrm{m}^{-2}$ and $1.2537 \mathrm{MJ} \mathrm{m}^{-2}$, and with the RRMSE of $10.02 \%, 8.62 \%$ and $11.88 \%$, respectively. Modified from the A-P model (group 1) by introducing air temperature, the models ST10 and ST9 had lower error indicators than the A-P model at Chongqing and Yichang, respectively, suggesting that inclusion of air temperature can improve the estimation accuracy of the A-P model. This result agrees well with the result from Chen and $\mathrm{Li}$ [20], and Chen et al [121] who found the modification to A-P model by introducing air temperature decreased the estimation error of the A-P model. By incorporating sunshine duration and air temperature models in Nigeria, Boluwaji and Onyedi [172] estimated solar radiation with a new model showing better performance over sunshine duration models. Lee [41] found the newly suggested equation with air temperature generally provided better estimations than the A-P model in Korean. These results further confirm our results at Chongqing and Yichang stations. Model ST19 showing similar performance to the A-P model at Wanzhou is consistent with the result of $\mathrm{Wu}$ et al [162] who reported that modification to A-P model by introducing air temperature performed similarly to the A-P model.

Among the sunshine duration - relative humidity models (Table 2), the models SR8, SR7 and SR 6 had the lowest estimation errors at Chongqing, Wanzhou and Yichang, respectively. The model SPr3 in group 5 performed best at Chongqing and Wanzhou. In group 4, only one model (SP1) was collected from literatures, and this model presented similar error indicators to the model SPr3 at the same station. Moreover, the best model at each site of Chongqing and Wanzhou in groups 3-5 performed similarly to the A-P model at the same station, generally indicating that individual inclusion of relative humidity, atmospheric pressure, and precipitation did not increase the estimation accuracy of the A-P model. These results are consist with the result from Chen and Li [20] who found the modifications to A-P model by individually introducing relative humidity, atmospheric pressure and precipitation gave similar performances to the A-P model. Meenal [173] compared 16 empirical models and also reported that exclusion of relative humidity did not affect the estimation accuracy of sunshine duration models in India. While Yildirim et al [13] found both models SR8 and SR7 significantly outperformed A-P model, as well as 14 sunshine duration models in his work.

In group 6 (Fig.5), the model SG7 had the highest error indicators. The model SG16, with similar performance as model SG6, was the most accuracy model at Chongqing and Yichang, with the lowest RMSE of $1.0356 \mathrm{MJ} \mathrm{m}^{-2}$ and $1.3861 \mathrm{MJ} \mathrm{m}^{-2}$, and with the RRMSE of $11.59 \%$ and 13.13\%, respectively. Except models SG6-7 and 16, other models showed similar error indicators at the same site for Chongqing and Yichang. Model SG 28 outperformed other models at Wanzhou, with the RMSE of $0.7893 \mathrm{MJ} \mathrm{m}^{-2}$ and RRMSE of $8.62 \%$, while models SG1-2, SG4-5, SG7, SG10-11, SG15 and SG 17 had higher error indicators than other models that present similar error indicators at this site.

Among the sunshine duration - temperature - relative humidity models (Fig.6), models STR3 and STR10 showed much higher estimation errors than other models. Models STR15, STR4 and STR16 performed best at Chongqing, Wanzhou and Yichang, with the RMSE of $0.8893 \mathrm{MJ} \mathrm{m}^{-2}, 0.7954 \mathrm{MJ} \mathrm{m}^{-2}$ and $1.2207 \mathrm{MJ} \mathrm{m}^{-2}$, and with the RRMSE of $9.96 \%, 8.68 \%$ and $11.57 \%$, respectively. While the error indicators of the models STR15 and STR16 were similar to those of models STR7-8 and STR14-16 at the same site for Chongqing and Yichang. At Wanzhou station, the best model STR4 showed very similar error indicators to the models 
STR4-5, STR7-9, STR11-12 and STR 14-17. Emad [174] compared the performances of model STR7 and some sunshine duration models in Egypt, and found that the model STR7 yielded better results over others. Falayi et al [85] observed that incorporating sunshine duration, temperature and relative humidity models yielded better precision than other models in Nigeria. These results are consistent with ours at Chongqing and Yichang where model STR7 showed lower estimation errors than the sunshine duration models.

In group 8 (Fig.7), the model STP9, which shows slightly lower error indicators than others at the same site for Chongqing and Yichang, had the lowest RMSE of $0.8952 \mathrm{MJ} \mathrm{m}^{-2}$ and $1.2267 \mathrm{MJ} \mathrm{m}^{-2}$, and the lowest RRMSE of $10.06 \%$ and $11.62 \%$, respectively. Model STP10 performeds best at Wanzhou where all the STP models showed very similar performances. Fan et al [45] compared the performances of models STP4-6 against other 10 models and found that model STP6 had higher accuracy than others in South China. While models STP9 and STP10 performed better than the STP6 in our study.

In groups 10 and 14-15 (Table2), only one model was collected for each group. Model STRW1 was superior to STPPr1 and SRP1 at the same site for Chongqing and Yichang, while model STPPr1 outperformed STRW1 and SRP1 at Wanzhou. In groups 9, 11-13 and 17-19, all the models in each group were found similar error indicators at the same site for Chongqing and Wanzhou. On average, model groups 9,11,12,14 and 17-18 had similar performances at Chongqing, and the error indicators were higher than those of groups 15 and 19-20 that also performed similarly at this station. At Wenzhou station, groups 9, 11-15, 17 and 19 presented similar average error indicators, which were slightly higher than those of group 18. Model groups 9, 10, 12-14 and 17 performed similarly at Yichang where groups 11, 15 and 18-20 also showed similar error indicators. Compared the performance of the model STRPr1 against the A-P model, Chen and Li [25] reported that air temperature, atmospheric pressure and relative humidity, as introduced in an additive form, accounted less for the improvement in accuracy of the A-P model. This result is consistent with our results at Wanzhou where both models had similar error indicators. However, the model STRPr1, as well as other STRPr models in group 13, showed better performances than the A-P model at Chongqing and Yichang. Ouali and Alkama [104] evaluated the performances of models STRP1, STRPW1, STRPW2 and STR7, and found that addition of precipitation and wind velocity increased the accuracy of the model employing sunshine fraction, temperature and relative humidity in Nigeria. Such models were found performing similarly in our study. Coulibaly and Ouedraogo [175] revised the A-P model using air temperature and sin of solar declination, and found this new model outperformed sunshine duration models in Africa. This agrees with our result at Chongqing and Yichang where group 11 had lower error indicators than A-P model. Adeala et al [102] compared the performances of models STRW1, S9, SR5 and STR7 in South Africa, and reported that STRW1 was the best one. This is confirmed by our results at Chongqing and Yichang, while all these models had similar error indictors at Wanzhou.

Among the sunshine duration - temperature - relative humidity - geographic factors models (Fig.8), models STRG12 and STRG4 performed best at Chongqing and Wanzhou, with the RMSE of $0.8973 \mathrm{MJ} \mathrm{m}^{-2}$ and $0.8623 \mathrm{MJ} \mathrm{m}^{-2}$, and with the RMSE of $10.05 \%$ and $9.41 \%$, respectively. Models TRG1-3 showed larger error indicators than STRG 4-13 that presented similar error indicators at the same site for the two stations. Model STRG7 was superior to 
other models at Yichang, with the RMSE of 1.2221 $\mathrm{MJ} \mathrm{m}^{-2}$ and RMSE of 11.58\%. Models STRG1-4 had higher error indicators than STRG 5-13 that performed similarly at this station.

In group 21(Fig.9), models T64 and T59 were the most accuracy ones for Chongqing and Wanzhou, with the RMSE of $1.0179 \mathrm{MJ} \mathrm{m}^{-2}$ and $1.2081 \mathrm{MJ} \mathrm{m}^{-2}$, and with the RMSE of $11.39 \%$ and $13.18 \%$, respectively. The error indicators of the two models were similar to those of T38, T52 and T54 at the same site for the two stations. Models T2-8, T18-19, T28, T35, T37, T39, T47-51, T53 and T61 performed similarly at the same site for Chongqing and Wanzhou, while models T1, T22-23, T45-46 and T57 presented larger error indicators than other models. At Yichang station, model T40 had the lowest RMSE of $1.3176 \mathrm{~m}^{-2}$ and RMSE of $12.48 \%$, which were similar to T26, T30-31, T33-34, T40-41, T52, T55-56 and T58-59. Models T2, T4-8, T10, T18-19, T28, T35, T37, T39, T49-51, T53, T61 and T63 also showed similar error indicators at this site, while models T23 and T25 presented higher error indicators than other models.

Among the temperature - relative humidity models (Fig.10), model TR11 outperformed other models at Chongqing, Wanzhou and Yichang, with the RMSE of $1.0897 \mathrm{MJ} \mathrm{m}^{-2}, 1.2757$ $\mathrm{MJ} \mathrm{m}^{-2}, 1.3531 \mathrm{MJ} \mathrm{m}^{-2}$, and with the RMSE of $12.20 \%, 13.92 \%$ and $12.82 \%$, respectively. Models TR1, TR4, TR7-8 and TR19 presented higher error indicators than other models. In group 23 (Table 2), the model TP7 was superior to TP1-6 that perform similarly at the same site. Models TPr3 and TG4 performed best in group 24 and 25, respectively. Modified from T41, T49, T5 and T19 by introducing relative humidity, precipitation, vapor pressure and geographic factor, respectively, the models TR11, TP7, TPr3 and TG4 showed smaller error indicators than the corresponding models T41, T49, T5 and T19. This result indicates that inclusion of relative humidity, precipitation, vapor pressure and geographic factor can increase estimation accuracy of the temperature models. Chen and Li [20] evaluated some modifications to the H-S model by introducing relative humidity and vapor pressure and reported similar conclusion to ours. Ouali and Alkama [104] discovered that the application of precipitation enhanced the performance of temperature models in Algeria, which is in agreement with our results. While Chen and $\mathrm{Li}$ [20] found the modification to the H-S model by introducing precipitation gave similar performance to the H-S model.

Models TRP5, TRPr4, TRG4, TPPr4 and TPG1 performed best in groups 26, 27, 28, 29 and 31 , respectively. While these models showed similar performances at Yichang, and their error indicators were similar to those of the model TRPG1 in group 32. Models TPG1 and TRG4, which had similar error indicators at Chongqing, outperformed models TRP5, TRPr4 and TPPr4 that also performed similarly at this site. Models TRP5, TRG4 and TRPG1 gave the similar estimations at Wanzhou. In group 30, only one model (TPW1) was collected from literatures, and this model presented higher error indicators than TRP5, TRPr4, TRG4, TPPr4, TPG1 and TRPG1 at the same site.

In group 33(Table 2), models R1-3 had much higher error indicators than R4-7. The model R6 had the lowest error indicators at Chongqing and Wanzhou, while the model R7 performed better than other models at Yichang. In groups 34-37, only one model was collected for each group, the model RP1 in group 35 was superior to P1(group 34), PG1(group 36) and Pr1(group 37) at the same site for Chongqing and Yichang, while the model Pr1 outperformed other models at Wanzhou. However, all these models presented higher error indicators than the models in groups 1-32. 
In order to give an overview of the best model in each group, the top three models with the smallest average error indicators of the three stations in each group are selected and presented in Table 3. If the number of the model in group is less than 3, all the models are selected. Overall, the model STP10 was the most accuracy one followed by STP9 and STRPG2, while their error indicators were similar to many models as shown in Table 3. This result is in agreement with the conclusions from Evrendilek and Ertekin [64], and Sonmete et al [65] who evaluated many empirical equations in Turkey, and the results showed that model STP10 was the most accuracy one. Besharat et al [2] reviewed 78 empirical models and concluded that the model S1 performed best for Iran. Yao et al [32] compared 118 equations and reported that the model S24 was superior to other models at Shanghai in China, while both models S1 and S24 were inferior to many models reviewed in our study. Despotovic et al [5] evaluated 101 equations using long term sunshine duration data throughout the world and concluded that the model presented by Khogali et al [176] gave the best estimations. Similar to Despotovic and his colleagues's work [5], Bayrakçı et al [9] compared 105 sunshine duration equations and found that the models presented by Veeran and Kumar [177] and Chegaar and Chibani [178] performed best in Turkey. In fact, the most accuracy equations reported by Despotovic et al [5], Bayrakçı et al [9] and Yao et al [32] were A-P model just with different coefficients. While the A-P model was inferior to many models according our results. However, it is noteworthy that many equations in their works had the same formulas just with different coefficients rather than locally calibrated. We do not support such comparisons because the empirical coefficients are site-dependent $[2,5,19,22]$ and greatly affected by topographical characteristics and local climate [10, 13], and thus unconditional utilizations are not appropriate. When sunshine duration data are not available, the model TPG1 performed best followed by TRG4 and TG4. Sonmete et al [65] found the model TPG2 was the best temperature-based model in Turkey, while this model was inferior to many temperature-based models in our study. Models TPG1, TRG4 and TG4 showed higher error indicators than STP10, STP9 and STRPG2, as well as many other models in groups1-20, indicating that the sunshine-based models outperform the temperature-based models and the empirical models employing other meteorological variables, which has been confirmed by many studies [2, 20-21, 47].

\section{Concludings}

Empirical model is the most widely used method to estimate global solar radiation. This paper comprehensively reviewed the empirical models using the commonly measured meteorological variables and geographic factors. In total, 294 different types of empirical models were collected from literatures. These models were classified into 37 groups according to the input meteorological variables, 162 models with the corresponding 20 groups accounting for $55.1 \%$ were reported for the sunshine-based models; 121 models with 12 groups representing $41.2 \%$ for the temperature-based models; and 11 models with 5 groups resulting to $3.7 \%$ for other models. Furthermore, these models were calibrated and evaluated at three meteorological stations in Three Gorges Reservoir Area in China to identify the most appropriate one for the specific applications.

The results suggest that the sunshine-based models are generally more accurate than the temperature-based models and the empirical models employing other meteorological 
variables. Overall, the model STP10 gave the best performance followed by STP9 and STRPG2, while the model TPG1 performed best followed by TRG4 and TG4 when sunshine duration data are unavailable.

The main novelty of this study is that, to our best knowledge, this is so far the most comprehensively review on empirical models for estimation of solar radiation using the commonly measured meteorological variables and geographic factors. Remarkable efforts have been made to estimate solar radiation with empirical models. However, it is still a challenging task to develop better accuracy models due to the complex process of radiation. Numerous evaluations seem to indicate that empirical models have far overreached their predictive limits. Thus, it is more convenient to select an appropriate one from literatures rather than developing new models. This comprehensive review has built an empirical model library providing an overall overview of the developed empirical models in literatures. Moreover, the collected models are evaluated and compared to assist the governments, scientists and engineers in selecting the most appropriate one for specific applications in agriculture, climate, ecology and energy studies.

The collected and reviewed model formulas were based on the long term meteorological data at thousands of stations throughout the world. Thus, these formulas have a large potential for applications on global scale. However, the main difficulty in limiting the universal applicability of the most accuracy models in our study to other regions is the empirical coefficients which are site-dependent $[19,22]$. Thus, it is clear from many literatures and our results that selecting a most accuracy model for estimation of solar radiation at any location of interest is not a viable work. This is as a result of its complexity, intrinsic quality of equipments, the topographical and the local climate characteristics [10, 13]. Nevertheless, it is reasonable that our conclusions are applicable to the regions with similar climatic conditions and topography. For other regions, the interested models can be collected from the empirical model library and evaluated to select the best model following the scheme of this study without having to check and review a large number of literatures, making our study would be a benchmark to select empirical models for estimating global solar radiation.

Due to the simplicity and operability yet reasonable accuracy, the empirical models are extensively studied and applied. While the commonly employed judgments criterions identifying the best model neglect the intrinsic quality of estimations [22]. Thus, the slight improvement of accuracy of the models with complex structure and more number of empirical coefficients is unable to prove the superiority to simple models yet satisfactory accuracy. This has been stressed by several studies [18, 179]. Accordingly, it is necessary to explore the optimal trade-off between the accuracy and the complexity, which is mainly depended on the application of the estimation and the data availability. Therefore, it is crucial to cooperate each other for developing a universal framework to guide the selection of the optimal empirical model.

\section{Acknowledgment}

The work was supported by Youth Innovation Promotion Association (2018417), National Natural Science Foundation of China (41501096, 41771460). We thank the National Meteorological Information Center for providing the long-term meteorological measurements 
records. Many thanks go to the anonymous reviewers for the comments on the manuscript.

\section{References}

[1] Yildirim HB, Özgür Çelik, Teke A, Barutçu B. Estimating daily global solar radiation with graphical user interface in eastern Mediterranean region of turkey. Renew Sustain Energy Rev 2018; 82:1528-37.

[2] Besharat F, Dehghan AA, Faghih AR. Empirical models for estimating global solar radiation: a review and case study. Renew Sustain Energy Rev 2013; 21(21): 798-821.

[3] Qin W, Wang L, Lin A, Zhang M, Xia X, Hu B. Comparison of deterministic and data-driven models for solar radiation estimation in china. Renew Sustain Energy Rev 2018; 81: 579-94.

[4] Haigh JD. The sun and the earth's climate. Living Rev Sol Phys 2007; 4(1): 2.

[5] Despotovic M, Nedic V, Despotovic D, Cvetanovic S. Review and statistical analysis of different global solar radiation sunshine models. Renew Sustain Energy Rev 2015; 52: 1869-80.

[6] Hernández-Escobedo Q, Fernández-García A, Manzano-Agugliaro F. Solar resource assessment for rural electrification and industrial development in the Yucatan Peninsula (Mexico). Renew Sustain Energy Rev 2017; 76: 1550-61.

[7] Tahir ZR, Asim M. Surface measured solar radiation data and solar energy resource assessment of Pakistan: a review. Renew Sustain Energy Rev 2018; 81: 2839-61.

[8] Giwa A, Alabi A, Yusuf A, Olukan T. A comprehensive review on biomass and solar energy for sustainable energy generation in Nigeria. Renew Sustain Energy Rev 2017; 69: 620-41.

[9] Bayrakçı HC, Demircan C, Keçebaş A. The development of empirical models for estimating global solar radiation on horizontal surface: a case study. Renew Sustain Energy Rev 2018; 81: 2771-82.

[10] Chukwujindu NS. A comprehensive review of empirical models for estimating global solar radiation in Africa. Renew Sustain Energy Rev 2017; 78: 955-95.

[11] Wang T, Wu G, Chen J, Cui P, Chen Z, Yan Y. Integration of solar technology to modern greenhouse in China: current status, challenges and prospect. Renew Sustain Energy Rev 2016; 70: 1178-88.

[12] Urraca R, Martinez-De-Pison E, Sanz-Garcia A, Antonanzas J, Antonanzas-Torres F. Estimation methods for global solar radiation: case study evaluation of five different approaches in central Spain. Renew Sustain Energy Rev 2017; 77: 1098-113.

[13] Yildirim HB, Teke A, Antonanzas-Torres F. Evaluation of classical parametric models for estimating solar radiation in the eastern Mediterranean region of turkey. Renew Sustain Energy Rev 2018; 82: 2053-65.

[14] Chen JL, Li GS, Wu SJ. Assessing the potential of support vector machine for estimating daily solar radiation using sunshine duration. Energy Convers Manage 2013; 75: 311-18.

[15] Deo RC, Şahin M. Forecasting long-term global solar radiation with an ANN algorithm coupled with satellite-derived (Modis) land surface temperature for regional locations in Queensland. Renew Sustain Energy Rev 2017; 72: 828-48. 
[16] Mohanty S, Patra PK, Sahoo SS. Prediction and application of solar radiation with soft computing over traditional and conventional approach-a comprehensive review. Renew Sustain Energy Rev 2016; 56: 778-96.

[17] Al-Rousan N, Isa NAM, Desa MKM. Advances in solar photovoltaic tracking systems: a review. Renew Sustain Energy Rev 2018; 82: 2548-69.

[18] Hassan MA, Khalil A, Kaseb S, Kassem MA. Independent models for estimation of daily global solar radiation: a review and a case study. Renew Sustain Energy Rev 2018; 82: $1565-75$.

[19] Paulescu M, Stefu N, Calinoiu D, Paulescu E, Pop N, Boata R, Mares O. Ångström-Prescott equation: physical basis, empirical models and sensitivity analysis. Renew Sustain Energy Rev 2016; 62: 495-506.

[20] Chen JL, Li GS. Estimation of monthly average daily solar radiation from measured meteorological data in Yangtze River Basin in China. Int J Climatol 2013; 33: 487-98.

[21] Mohamed SM, Taqiy EB, RedaT, Kacem G. Introducing the best model for estimation the monthly mean daily global solar radiation on a horizontal surface (Case study Algeria). Renew Sustain Energy Rev 2014; 36: 194-202

[22] Zhang J, Zhao L, Deng S, Xu W, Zhang Y. A critical review of the models used to estimate solar radiation. Renew Sustain Energy Rev 2017; 70: 314-29.

[23] Chen JL, Xiao BB, Chen CD, Wen ZF, Jiang Y, Lv MQ, Li GS. Estimation of monthly-mean global solar radiation using MODIS atmospheric product over China. J Atmos Sol-Terr Phy 2014; 110: 63-80.

[24] Chen JL, Li GS, Xiao BB, Wen ZF, Lv MQ, Chen CD, Jiang Y, Wang XX, Wu SJ. Assessing the transferability of support vector machine model for estimation of global solar radiation from air temperature. Energy Convers Manage 2015; 89: 318-29.

[25] Chen JL, Li GS. Evaluation of support vector machine for estimation of solar radiation from measured meteorological variables. Theor Appl Climatol 2014; 115: 627-38.

[26] Chen JL, Liu HB, Wu W, Xie DT. Estimation of monthly solar radiation from measured temperatures using support vector machines-A case study. Renew Energ 2011; 36(1): 413-20.

[27] Khorasanizadeh H, Mohammadi K. Diffuse solar radiation on a horizontal surface: reviewing and categorizing the empirical models. Renew Sustain Energy Rev 2016; 53: 338-62.

[28] Teke A, Yıldırım HB, Özgür Çelik. Evaluation and performance comparison of different models for the estimation of solar radiation. Renew Sustain Energy Rev 2015; 50:1097-107.

[29] Chen JL, Xiao BB, Chen CD, Wen ZF, Jiang Y, Lv MQ, Wu SJ, Li GS. Estimation of solar radiation using two-step method in Yangtze River basin in China. MAUSAM, 2015, 66(2): 225-36.

[30] Angstrom A. Solar and terrestrial radiation. Q J Roy Meteor Soc 924; 50: 121-26.

[31] Prescott JA. Evaporation from a water surface in relation to solar radiation. T Roy Soc South Aust 1940; 64: 114-8.

[32] Yao W, Li Z, Wang Y, Jiang F, Hu L. Evaluation of global solar radiation models for Shanghai, China. Energy Convers Manag 2014; 84: 597-612. 
[33] Ögelman H, Ecevit A, Tasdemiro E. A new method for estimating solar radiation from bright sunshine data. Sol Energy 1984; 33: 619-25.

[34] Bahel V, Bakhsh H, Srinivasan R. A correlation for estimation of global solar radiation. Energy 1987; 12: 131-5.

[35] Almorox J, Hontoria C. Global solar radiation estimation using sunshine duration in Spain. Energy Convers Manag 2004; 45: 1529-35.

[36] Ampratwum DB, Dorvio ASS. Estimation of solar radiation from the number of sunshine hours. Appl Energ 1999; 63: 161-7.

[37] Manzano A, Martín ML, Valero F, Armenta C. A single method to estimate the daily global solar radiation from monthly data. Atmos Res 2015; 166:70-82.

[38] Mohammadi K, Shamshirband S, Anisi MH, Alam KA, Petković D. Support vector regression based prediction of global solar radiation on a horizontal surface. Energy Convers Manag 2015; 91: 433-41.

[39] Teke A, Yildirim HB. Estimating the monthly global solar radiation for Eastern Mediterranean Region. Energy Convers Manag 2014; 87: 628-35.

[40] Meher C, Yves G, Jompob W. Solar radiation mapping using sunshine duration based models and interpolation techniques: application to Tunisia. Energy Convers Manag 2015; 101: 203-15.

[41] Lee Khil-Ha. Improving the correlation between incoming solar radiation and sunshine hour using DTR. Int J Climatol 2015; 35(3): 361-74.

[42] Saffaripour MH, Mehrabian MA, Bazargan. Predicting solar radiation fluxes for solar energy system applications. Int J Environ Scu Te 2013; 10(4): 761-8.

[43] Bakirci K. Prediction of global solar radiation and comparison with satellite data. J Atmos Sol-Terr Phy 2017; 152: 41-9.

[44] Liu JD, Liu JM, Linderholm HW, Chen DL, Yu Q, Wu DG. Observation and calculation of the solar radiation on the Tibetan plateau. Energy Convers Manag 2012: 57(2): 23-32.

[45] Fan J, Wang X, Wu L, Zhang F, Bai H, Lu X. New combined models for estimating daily global solar radiation based on sunshine duration in humid regions: a case study in south China. Energy Convers Manag 2018; 156: 618-25.

[46] Okonkwo GN, Nwokoye AOC. Estimating global solar radiation from temperature data in Minna location. Eur Sci J 2014; 10: 254-64.

[47] Khorasanizadeh H, Mohammadi K, Jalilvand M. A statistical comparative study to demonstrate the merit of day of the year-based models for estimation of horizontal global solar radiation. Energy Convers Manag 2014; 87: 37-47.

[48] Sharifi SS, Rezaverdinejad V, Nourani V. Estimation of daily global solar radiation using wavelet regression, ANN, gep and empirical models: a comparative study of selected temperature-based approaches. J Atmos Sol-Terr Phy 2016; 149: 131-45.

[49] Hargreaves GH, Samani ZA. Estimating potential evaporation. J Irrig Drain Eng 1982; 108: 225-30.

[50] Benghanem M, Mellit A. A simplified calibrated model for estimating daily global solar radiation in Madinah, Saudi Arabia. Theor Appl Climatol 2014; 115: 197-205.

[51] Hassan GE, Youssef ME, Mohamed ZE, Ali MA, Hanafy AA. New temperature-based models for predicting global solar radiation. Appl Energ 2016; 179: 437-50. 
[52] Li MF, Tang XP, Wu W, Liu HB. General models for estimating daily global solar radiation for different solar radiation zones in mainland china. Energy Convers Manag 2013; 70(70): 139-48.

[53] Korachagaon I, Bapat VN. General formula for the estimation of global solar radiation on earth's surface around the globe. Renew Energ 2012; 41(4): 394-400.

[54] Chen R, Kang E, Lu S, Yang J, Ji X, Zhang Z. New methods to estimate global radiation based on meteorological data in China. Energy Convers Manage 2006; 47:2991-8.

[55] Bristow KL, Campbell GS. On the relationship between incoming solar radiation and daily maximum and minimum temperature. Agr For Meteorol 1984; 31:159-66.

[56] Fan J, Chen B, Wu L, Zhang F, Lu X, Xiang Y. Evaluation and development of temperature-based empirical models for estimating daily global solar radiation in humid regions. Energy 2018; 144: 903-14.

[57] Goodin DG, Hutchinson JMS, Vanderlip RL, Knapp MC. Estimating solar irradiance for crop modeling using daily air temperature data. Agron. J. 1999; 91: 845-51.

[58] Kolebaje OT, Sika AI, Akinyemi P. Estimating solar radiation in Ikeja and Port Harcourt via correlation with relative humidity and temperature. Int J Energy Prod Manag 2016; 1(3):253-62.

[59] Adaramola MS. Estimating global solar radiation using common meteorological data in Akura, Nigeria. Renew Energ 2012; 47:38-44.

[60] Kamal S. Correlation of global solar radiation with common geographical and meteorological parameters for Damascus province, Syria. Energy Convers Manag 2006; 47(4): 331-45.

[61] Akpabio LE, Udo SO, Etuk SE. Empirical correlations of global solar radiation with meteorological data for Onne, Nigeria. Turk J Phys. 2004; 28: 205-12.

[62] Chen JL, He L, Chen Q, Lv MQ, Zhu HL, Wen ZF, Wu SJ. Study of monthly mean daily diffuse and direct beam radiation estimation with MODIS atmospheric product. Renew Energ 2018; 132: 221-32.

[63] Bakirci K. Models of solar radiation with hours of bright sunshine: a review. Renew Sustain Energy Rev 2009; 13(9): 2580-88.

[64] Evrendilek F, Ertekin C. Assessing solar radiation models using multiple variables over turkey. Clim Dynam 2008; 31(2-3): 131-49.

[65] Sonmete MH, Ertekin C, Menges HO, Haciseferoğullari H, Evrendilek F. Assessing monthly average solar radiation models: a comparative case study in turkey. Environ Monit Assess 2011; 175(1-4): 251.

[66] Fu BJ, Wu BF, Lu YH, Xu ZH, Cao JH, Niu D, Yang GS, Zhou YM. Three Gorges Project: Efforts and challenges for the environment. Prog Phys Geog 2010; 34(6): 741-54.

[67] He HP, Wu SJ, Ma MH, Wen ZF, Lv MQ, Chen JL. Spatial distribution and temporal trend of pan evaporation in the three gorges reservoir area and its surroundings during 1952-2013. Appl Ecol Env Res 2017; 15(3):1594-610.

[68] Wen Z, Wu S, Chen J, Lv LM. NDVI indicated long-term interannual changes in vegetation activities and their responses to climatic and anthropogenic factors in the three gorges reservoir region, china. Sci Total Environ 2017; 574: 947-59. 
[69] Lv MQ, Chen JL, Mirza Zakaria A, Chen CD, Wen ZF, Jiang Y, Ma MH, Wu SJ. Spatial distribution and temporal variation of reference evapotranspiration in the Three Gorges Reservoir area during 1960-2013. Int J Climatol 2016; 36: 4497-511.

[70] Chen JL, He L, Wen ZF, Lv MQ, Yi XX, Wu SJ. A general empirical model for estimation of solar radiation in Yangtze River basin. Appl Ecol Env Res 2018; 16(2): 1471-82.

[71] Moradi I. Quality control of global solar radiation using sunshine duration hours. Energy 2009; 34: 1-6.

[72] Chen JL, Li GS. Parameterization and mapping of solar radiation in data sparse regions. Asia-Pac J Atmos Sci. 2012; 48(4): 423-31.

[73] Liu XY, Mei XR, Li YZ, Wang QS, Jensen JR, Zhang XQ. Evaluation of temperature-based global solar radiation models in China. Agr For Meteorol 2009; 149:1433-46.

[74] Yang Y, Wang D, Lv W, Mo Y, Ding L. Solar radiation standard and its values transfer system China, www.wmo.int/pages/prog/www/IMOP/publications/IOM-96_ECO-2008 /P1(52)_Yang_China.pdf.

[75] China Meteorological Administration (CMA). Specifications for surface meteorological observation. QX/T45-2007; 1979. p. 187.

[76] Allen RG, Pereira LS, Raes D, Smith M. Crop evapotranspiration guidelines for computing crop water requirements e FAO irrigation and drainage paper 56. Rome: Food and Agriculture Organization of the United Nations; 1998.

[77] Qin J, Chen Z, Yang K, Liang S, Tang W. Estimation of monthly-mean daily global solar radiation based on MODIS and TRMM products. Appl Energ 2011; 88: 2480-9.

[78] Shi GY, HayasakaT, Ohmura A ,Chen ZH, Wang B, Zhao JQ, Xu L. Data quality assessment and the long-term trend of ground solar radiation in China. J Appl Meteorol Climatol 2008; 47(4): 1006-16.

[79] Feng S, Hu Q, Qian W. Quality control of daily meteorological data in China, 1951-2000: a new dataset. Int J Climatol 2004; 24(7): 853-70.

[80] Tang W, Yang K, He J, Qin J. Quality control and estimation of global solar radiation in China. Sol Energy 2010; 84(3): 466-75.

[81] Katiyar AK, Katiyar VK, Kumar A, Pandey CK. Sixth order empirical relationship for estimating global solar radiation from sunshine hours. Jour PAS 2008; 15:156-65.

[82] Behrang MA, Assareh E, Noghrehabadi AR, Ghanbarzadeh A. New sunshine-based models for predicting global solar radiation using PSO (particle swarm optimization) technique. Energy 2011; 36(5): 3036-49.

[83] BakiRci K. Correlations for estimation of daily global solar radiation with hours of bright sunshine in Turkey. Energy 2009; 34(4): 485-501.

[84] Togrul IT, Togrul H, Evin D. Estimation of global solar radiation under clear sky radiation in Turkey. Renew Energ 2000; 21:271-87.

[85] Falayi EO, Adepitan JO, Rabiu AB. Empirical models for the correlation of global solar radiation with meteorological data for Iseyin, Nigeria. Int J Phys Sci 2008; 3: 210-6.

[86] Olayinka S. Estimation of global and diffuse solar radiations for selected cities in Nigeria. Int J Energy Environ Eng 2011; 3: 13-33. 
[87] Weiss A, Hays CJ, Hu Q, Easterling WE. Incorporating bias error in calculating solar irradiance: Implications for crop yield simulations. Agron J 2001; 93: 1321-26.

[88] Garcia JV. Principios fi'sicos de la climatologi'a. Ediciones UNALM. Universidad Nacional Agraria La Molina 1994; pp. 244

[89] Donatelli M, Marletto V. Estimating surface solar radiation by means of air temperature. In Pro 1 Proceedings of the third ESA congress1994; pp. 352-3.

[90] Lewis G. Estimates of irradiance over Zimbabwe. Sol Energy 1983; 31: 609-12.

[91] Pu S, Lin W. Correlations to estimate monthly total solar radiation on horizontal surfaces at Kunming, China. Energy Convers Manag 2000; 41(4): 367-74.

[92] Elagib N, Mansell MG. New approaches for estimating global solar radiation across Sudan. Energy Convers Manag 2000; 41: 419-34.

[93] Chen RS, Lu S, Kang E, Yang J, Ji X. Estimating daily global radiation using two types of revised models in China. Energy Convers Manage 2006; 47: 865-78.

[94] Zhou J, Wu YZ, Yan G. General formula for estimation of monthly average daily global solar radiation in China. Energy Convers Manage 2005; 46: 257-68.

[95] Togrul IT, Onat E. 1999 A study for estimating solar radiation in Elaziğ using geographical and meteorological data. Energy Convers Manag 1999; 40(14): 1577-84.

[96] Thornton PE, Running SW. An improved algorithm for estimating daily solar radiation from measurements of temperature, humidity, and precipitation. Agric For Meteorol 1999; 93: 211-28.

[97] Al-Salihi AM, Kadum MM, Mohammed AJ. Estimation of global solar radiation on horizontal surface using routine meteorological measurements for different cities in Iraq. Asian J Sci Res 2010; 3(4): 240-8.

[98] Ododo JC, Sulaiman AT, Aidan J, Yuguda MM, Ogbu FA. The importance of maximum air temperature in the parameterization of solar radiation in Nigeria. Renew Energ 1995; 6: 751-63.

[99] Chen R, Kang E, Ji X, Yang J, Zhang Z. Trends of the global radiation and sunshine hours in 1961-1998 and their relationships in China. Energy Convers Manag 2006; 47: 2859-66.

[100] Kirmani S, Jamil M, Rizwan M. Empirical correlation of estimating global solar radiation using meteorological parameters. Int J Sustain Energy 2015; 34(5):327-39.

[101] Trabea AA. Correlation of global solar radiation with meteorological parameters over Egypt. Renew Energ 2000; 21: 297-308.

[102] Adeala AA, Huan Z, Enweremadu CC. Evaluation of global solar radiation using multiple weather parameters as predictors for South Africa Provinces. Therm Sci 2015;19: 495-509.

[103] Ajayi OO, Ohijeagbon OD, Nwadialo CE, Olasope O. New model to estimate daily global solar radiation over Nigeria. Sustain Energy Technol Assess 2014; 5: 28-36.

[104] Ouali K, Alkama R. A new model of global solar radiation based on meteorological data in Bejaia City, Algeria. J Sol Energy 2014; 1-9.

[105] Zou L, Wang L, Lin A, Zhu H, Peng Y, Zhao Z. Estimation of global solar radiation using an artificial neural network based on an interpolation technique in southeast china. J Atmos Sol-Terr Phy 2016; 146: 110-22. 
[106] Li HS, Cao F, Bu XB, Zhao L. Models for calculating daily global solar radiation from air temperature in humid regions-A case study. Environ Prog Sustain Energy 2015; 34(2): 595-9.

[107] Li MF, Liu HB, Guo PT, Wu W. Estimation of daily solar radiation from routinely observed meteorological data in Chongqing, China. Energy Convers Manage 2010; 51(12): 2575-9.

[108] Quej VH, Almorox J, Ibrakhimov M, Saito L. Empirical models for estimating daily global solar radiation in Yucatán Peninsula, Mexico. Energy Convers Manag 2016; 110 : 448-56.

[109] Richardson AG, Reddy KR. Assessment of solar radiation models and temporal averaging schemes in predicting radiation and cotton production in the southern United States. Clim Res 2004; 27(2): 85-103.

[110] Meza FJ, Yebra ML. Estimation of daily global solar radiation as a function of routine meteorological data in Mediterranean areas. Theor Appl Climatol 2016; 125(3): 479-88.

[111] Mubiru J, Banda EJKB, Ujanga FD, Senyonga T. Assessing the performance of global solar radiation empirical formulations in Kumpala, Uganda. Theor Appl Climatol 2007; 87: $179-84$.

[112] Reddy SJ. The estimation of global solar radiation and evaporation through precipitation - a note. Sol Energy 1987; 38: 97-104.

[113] El-Metwally M. Sunshine and global solar radiation estimation at different sites in Egypt. J Atmos Sol-Terr Phys 2005; 67:1331-42.

[114] Gana NN, Akpootu DO. Angstrom type empirical correlation for estimating global solar radiation in North-Eastern Nigeria. Int J Eng Sci 2013; 2: 58-78.

[115] Coppolino S. A new correlation between clearness index and relative sunshine. Renew Energ 1994; 4(4): 417-23.

[116] Louche A, Notton G, Poggi P, Simonnot G. Correlations for direct normal and global horizontal irradiation on a French Mediterranean site. Sol Energy 1991;46: 261-6.

[117] Newland FJ. A study of solar radiation models for the coastal region of South China. Sol Energy 1988; 31:227-35.

[118] Bakirci K. Correlations for estimation of solar radiation on horizontal surface. J Energ Eng 2008; 134(4):130-4.

[119] Sambo AS, Doyle MDC. The correlation of global and diffuse solar radiation components with meteorological data for Zaria. Nigerian J Sol Energ 1988; 7: 16-27.

[120] Abdallah YAG. New correlation of global solar radiation with meteorological parameters for Bahrain, Sol Energy 1994; 16:111-20.

[121] Chen RS, Ersi K, Yang JP, Lu SH, Zhao WZ. Validation of five global radiation models with measured daily data in China. Energy Convers Manage 2004; 45:1759-69.

[122] Elagib NA, Babiker SF, Alvi SH. New empirical models for global solar radiation over Bahrain. Energy Convers Manag 1998; 39(8): 827-35.

[123] Swartman RK, Ogunlade O. Solar radiation estimates from common parameters, Sol Energy 1967; 11:170-72.

[124] Glower J, McGulloch JSG. The empirical relation between solar radiation and hours of sunshine. Q J Roy Meteor Sol 1958; 84: 172. 
[125] Bennett I. Monthly maps of mean daily insolation for United States. Sol Energy 1965; 9: 145-59.

[126] Barbaro S, Coppolino S, Leone C. Global solar radiation in Italy. Sol Energy 1978, 20(5): 431-5.

[127] Dogniaux R, LemoineM. Classification of radiation sites in terms of different indices of atmospheric transparency. Solar Energy research and development in the European Community (Series F, Vol. 2). 1983; Dordrecht: Reidel.

[128] Kilic A, Ozturk A. Solar Energy, solar radiation and flate-plate collectors (in Turkish). Turkey: Ankara, 1984.

[129] Rehman S. Solar radiation over Saudi Arabia and comparisons with empirical models. Energy 1998; 23: 1077-82.

[130] Gopinathan KK. A simple method for predicting global solar radiation on a horizontal surface. Sol wind Technol 1988; 5(5): 581-3.

[131] Klabzuba J, Bures R, KoznarovaV. Model calculation of daily sums of global radiation used in growth models. In Proceedings of the bioclimatology labour hours. Zvolen, 1999; p. 121-2.

[132] Onyango FN. On the estimation of global solar insolation. Sol Energy 1983; 31(1): 69-71.

[133] Garg HP, Garg ST. Prediction of global solar radiation from bright sunshine hours and other meteorological parameters. Solar-India, proceedings on national solar Energy convention. New Delhi: Allied Publishers; 1982 p. 1004-7.

[134] Lin WX, Gao WF. Correlations for estimating monthly average global and diffuse solar radiation on horizontal surfaces at Tengchong, China. Energy Convers Manage 1999; 40:505-8.

[135] Kuye A, Jagtap SS. Correlation of solar radiation with climatological data for port Harcourt, Nigeria. Int J Climatol 2010; 14(7): 815-25.

[136] Ojosu JO, Komolafe LK. Models for estimating solar radiation availability in South Western Nigeria. Nigerian J Sol Energ 1987; 6: 69-77.

[137] Sayigh AAM. Estimation of total solar radiation intensity - a universal formula. J Engng Sci 1979; 5(1): 44-55.

[138] Sabbagh JA, Sayigh AAM, El-Salam EMA. Estimation of the total solar radiation from meteorological data. Sol Energy, 1977; 19(3):307-11.

[139] Reddy SJ. An empirical method for the estimation of total solar radiation. Sol Energy 1971; 13(2): 289-90.

[140] Richardson CW. Weather simulation for crop management models. T ASABE 1985; 28: 1602-6.

[141] Hargreaves GL, Hargreaves GH, Riley JP. Irrigation water requirements for Senegal River Basin. J Irrig Drain Eng 1985; 111: 265-75.

[142] Hunt LA, Kucharb L, Swanton CJ. Estimation of solar radiation for use in crop modeling. Agric For Meteorol 1998; 91:293-300.

[143] Awachie IRN, Okeke CE. New empirical solar model and its use in predicting global solar irradiation. Niger J Sol Energy 1990; 9: 143-56.

[144] Panday CK, Katiyar AK. Temperature base correlation for the estimation of global solar radiation on horizontal surface, Int $\quad J \quad$ Energy Environ 2010; 1(4): 737-44. 
[145] Meza F, Varas E. Estimation of mean monthly solar global radiation as a function of temperature. Agric For Meteorol 2000; 100:231-41.

[146] Donatelli, Campbell GS. A simple model to estimate global solar radiation. In: Proceedings of the fifth European society of agronomy congress, Nitra, Slovak Republic; 1998. p. 133-4.

[147] Abraha MG, Savage MJ. Comparison of estimates of daily solar radiation from air temperature range for application in crop simulations. Agric For Meteorol 2008; 148 : 401-16.

[148] Winslow JC, Hunt ER, Piper SC. A globally applicable model of daily solar irradiance estimated from air temperature and precipitation data. Ecol Model 2001; 143: 227-43.

[149] Almorox J, Hontoria C, Benito M. Models for obtaining daily global solar radiation with measured air temperature data in Madrid (Spain). Appl Energy 2011; 88: 1703-9.

[150] Ertekin C, Yaldiz O. Estimation of monthly average daily global radiation on horizontal surface for Antalya, Turkey. Renew Energ 1999; 17: 95-102.

[151] Li H, Cao F, Wang X, Ma W. A temperature-based model for estimating monthly average daily global solar radiation in china. The Scientific World Journal 2014; 3: 128754.

[152] Ohunakin OS, Adaramola MS, Oyewolu OM, Fagbenle RO. Correlations for estimating solar radiation using sunshine hours and temperature measurement in OSogbo, Osun state, Nigeria. Front Energy 2013:1-9.

[153] Samani Z. Estimating solar radiation and evapotranspiration using minimum climatological data. J Irrig Drain Eng 2000; 126: 265-7.

[154] Li MF, Fan L, Liu HB, Guo PT, Wu W. A general model for estimation of daily global solar radiation using air temperatures and site geographic parameters in southwest china. J Atmos Sol-Terr Phy 2013; 92(14): 145-50.

[155] Okundamiya MS, Nzeako AN. Estimation of diffuse solar radiation for selected cities in Nigeria. ISRN Renew Energy 2011; 439410.

[156] Jahani Babak, Dinpashoh Y, Raisi Nafchi Atefeh. Evaluation and development of empirical models for estimating daily solar radiation. Renew Sustain Energy Rev 2017; 73: 878-91.

[157] Almorox J, Bocco M, Willington E. Estimation of daily global solar radiation from measured temperatures at Cañada de Luque, Córdoba, Argentina. Renew Energ 2013; 60: 382-7.

[158] Dincer I, Dilmac S, Ture IE, Edin M. A simple technique for estimating solar radiation parameters and its application for Gebze. Energy Convers Manag 1995; 37(2):183-98.

[159] El-Sebaii AA, Al-Ghamdi AA, Al-Hazmi FS, Faidah A. Estimation of global solar radiation on horizontal surfaces in Jeddah, Saudi Arabia. Energy Policy 2009; 37: 3645-9.

[160] Ododo JC. Prediction of solar radiation using only maximum temperature and relative humidity South-east and north-east Nigeria. Energy Convers Manag 1997; 38(18): 1807-14.

[161] De Jong R, Stewart DW. Estimating global solar radiation from common meteorological observations in western Canada. Can J Plant Sci 1993; 73: 509-18. 
[162] Wu G, Liu Y, Wang T. Methods and strategy for modeling daily global solar radiation with measured meteorological data - a case study in Nanchang station, China. Energy Convers Manag 2007;48:2447-52.

[163] Allen R. Self calibrating method for estimating solar radiation from air temperature. J Hydrol Eng1997; 2: 56-67.

[164] Annandale J, Jovanovic N, Benade N, Allen R. Software for missing data error analysis of Penman-Monteith reference evapotranspiration. Irrig Sci 2002; 21:57-67.

[165] Mahmood R, Hubbard KG. Effect of time of temperature observation and estimation of daily solar radiation for the Northern Great Plains, USA. Agron J 2002; 94:723-33

[166] Ball RA, Purcell LC, Carey SK. Evaluation of solar radiation prediction models in North America. Agron J 2004; 96:391-7

[167] Yorukoglu M, Celik AN. A critical review on the estimation of daily global solar radiation from sunshine duration. Energy Convers Manage 2006; 47: 2441-50.

[168] Ertekin C, Evrendilek F. Spatio-temporal modeling of global solar radiation dynamics as a function of sunshine duration for Turkey. Agric For Meteorol 2007; 145: 36-47.

[169] Liu XY, Mei XR, Li YZ, Zhang YQ, Wang QS. Calibration of the Angstrom- Prescott coefficients $(a, b)$ under different time scales and their impacts in Estimating global solar radiation in the Yellow River basin. Agric For Meteorol 2009; 149: 697-710.

[170] Katiyar AK, Pandey CK. Simple correlation for estimating the global solar radiation on horizontal surfaces in India. Energy 2010; 35: 5043-8.

[171] Chen JL, Li GS. Assessing effect of time scale on the solar radiation-sunshine duration relationship. IDOJARAS 2012; 116(2): 123-43.

[172] Boluwaji MO, Onyedi DO. Comparative study of ground measured, satellite derived, and estimated global solar radiation data in Nigeria. J Sol Energy 2016; 10: 1-7.

[173] Meenal R, Selvakumar AI. Assessment of SVM, empirical and ANN based solar radiation prediction models with most influencing input parameters. Renew Energ 2018; 121: 324-43.

[174] Emad AA. Statistical comparison between empirical models and artificial neutral network method for global solar radiation at Qena, Egypt. J Multidiscip Eng Sci Technol 2015; 2:1899-906.

[175] Coulibaly O, Ouedoraogo A. Correlation of global solar radiation of eight synoptic stations in Burkina Faso based on linear and multiple linear regression methods. J Sol Energy 2016:1-12.

[176] Khogali A, Ramadan M, Ali Z, Fattah Y. Global and diffuse solar irradiance in Yemen. Sol Energy 1983; 31(1): 55-62.

[177] Veeran PK, Kumar S. Analysis of monthly average daily global radiation and monthly average sunshine duration at two tropical locations. Renew Energy 1993; 3: 935-9.

[178] Chegaar M, Chibani A. Global solar radiation estimation in Algeria. Energy Convers Manag 2001; 42:967-73.

[179] Li H, Ma W, Lian Y, Wang X, Zhao L. Global solar radiation estimation with sunshine duration in Tibet, China. Renew Energ 2011; 36: 3141-5. 
Table 1 Empirical models for estimation of global solar radiation in literatures

\begin{tabular}{|c|c|c|c|c|}
\hline $\begin{array}{l}\text { Model } \\
\text { group }\end{array}$ & $\begin{array}{l}\text { Model } \\
\text { ID }\end{array}$ & Equation & Input variables & Reference \\
\hline Group 1 & $\mathrm{~S} 1$ & $\mathrm{Rs} / \mathrm{Ra}=\mathrm{b}_{1}^{\mathrm{S} / \mathrm{S} 0}$ & $\mathrm{Ra}, \mathrm{S}, \mathrm{S}_{0}$ & El-Metwally [113] \\
\hline Group 1 & $\mathrm{~S} 2$ & $\mathrm{Rs}=\mathrm{b}_{1} \exp \left(\mathrm{b}_{2} \mathrm{~S}\right)$ & $\mathrm{S}$ & Lewis [90] \\
\hline Group 1 & $\mathrm{~S} 3$ & $\mathrm{Rs} / \mathrm{Ra}=\mathrm{b}_{1} \mathrm{~S} / \mathrm{S}_{0}$ & $\mathrm{Ra}, \mathrm{S}, \mathrm{S}_{0}$ & Gana and Akpootu [114] \\
\hline Group 1 & $\mathrm{~S} 4$ & $\mathrm{Rs} / \mathrm{Ra}=\mathrm{b}_{1}\left(\mathrm{~S} / \mathrm{S}_{0}\right)^{\mathrm{b} 2}$ & $\mathrm{Ra}, \mathrm{S}, \mathrm{S}_{0}$ & Elagib and Mansell [92] \\
\hline Group 1 & S5 & $\mathrm{Rs} / \mathrm{Ra}=\mathrm{e}^{\mathrm{b} 1}\left(\mathrm{~S} / \mathrm{S}_{0}\right)^{\mathrm{b} 2}$ & $\mathrm{Ra}, \mathrm{S}, \mathrm{S}_{0}$ & Coppolino [115] \\
\hline Group 1 & S6 & $\begin{array}{l}\mathrm{Rs} / \mathrm{Ra}=\mathrm{b}_{1}(\mathrm{~S} / \mathrm{Sn})^{\mathrm{b} 2} \\
1 / \mathrm{Sn}=0.8706 / \mathrm{S}_{0}+0.0003\end{array}$ & $\mathrm{Ra}, \mathrm{S}, \mathrm{S}_{0}$ & Togrul and Togrul [84] \\
\hline Group 1 & S7 & $\mathrm{Rs} / \mathrm{Ra}=\mathrm{b}_{1} \exp \left(\mathrm{b}_{2} \mathrm{~S} / \mathrm{S}_{0}\right)$ & $\mathrm{Ra}, \mathrm{S}, \mathrm{S}_{0}$ & Elagib and Mansell [92] \\
\hline Group 1 & S8 & $\mathrm{Rs} / \mathrm{Ra}=\mathrm{b}_{1} \exp \left(-\left(\left(\mathrm{S} / \mathrm{S}_{0}-\mathrm{b}_{2}\right) / \mathrm{b}_{3}\right)^{2}\right)$ & $\mathrm{Ra}, \mathrm{S}, \mathrm{S}_{0}$ & Yildirim et al [1] \\
\hline Group 1 & S9 & $\mathrm{Rs} / \mathrm{Ra}=\mathrm{a}+\mathrm{b}_{1} \mathrm{~S} / \mathrm{S}_{0}$ & $\mathrm{Ra}, \mathrm{S}, \mathrm{S}_{0}$ & Prescott [31] \\
\hline Group 1 & S10 & $\mathrm{Rs} / \mathrm{Ra}=\mathrm{a}+\mathrm{b}_{1} \mathrm{~S} / \mathrm{Sn}$ & $\mathrm{Ra}, \mathrm{S}, \mathrm{S}_{0}$ & Louche et al [116] \\
\hline Group 1 & S11 & $\mathrm{Rs} / \mathrm{Ra}=\mathrm{a}+\mathrm{b}_{1}\left(\mathrm{~S} / \mathrm{S}_{0}\right)^{\mathrm{b} 2}$ & $\mathrm{Ra}, \mathrm{S}, \mathrm{S}_{0}$ & Elagib and Mansell [92] \\
\hline Group 1 & S12 & $\mathrm{Rs} / \mathrm{Ra}=\mathrm{a}+\mathrm{b}_{1} \log \left(\mathrm{S} / \mathrm{S}_{0}\right)$ & $\mathrm{Ra}, \mathrm{S}, \mathrm{S}_{0}$ & Ampratwum and Dorvio [36] \\
\hline Group 1 & $\mathrm{~S} 13$ & $\mathrm{Rs} / \mathrm{Ra}=\mathrm{a}+\mathrm{b}_{1} \exp \left(\mathrm{S} / \mathrm{S}_{0}\right)$ & $\mathrm{Ra}, \mathrm{S}, \mathrm{S}_{0}$ & Almorox Hontoria [35] \\
\hline Group 1 & $\mathrm{~S} 14$ & $\mathrm{Rs} / \mathrm{Ra}=\mathrm{b}_{1} \sin \left(\mathrm{b}_{2} \mathrm{~S} / \mathrm{S}_{0}+\mathrm{b}_{3}\right)$ & $\mathrm{Ra}, \mathrm{S}, \mathrm{S}_{0}$ & Yildirim et al [1] \\
\hline Group 1 & $\mathrm{~S} 15$ & $\mathrm{Rs}=\mathrm{a}+\mathrm{a}_{1} \mathrm{Ra}+\mathrm{b}_{2} \mathrm{~S}$ & $\mathrm{Ra}, \mathrm{S}$ & Li et al [52] \\
\hline Group 1 & S16 & $\mathrm{Rs}=\mathrm{a}+\mathrm{a}_{1} \mathrm{Ra}+\mathrm{b}_{2} \mathrm{~S} / \mathrm{S}_{0}$ & $\mathrm{Ra}, \mathrm{S}, \mathrm{S}_{0}$ & Togrul and Onat [95] \\
\hline Group 1 & S17 & $\mathrm{Rs} / \mathrm{Ra}=\mathrm{a}+\mathrm{b}_{1} \mathrm{~S} / \mathrm{S}_{0}+\mathrm{b}_{2} \exp \left(\mathrm{S} / \mathrm{S}_{0}\right)$ & $\mathrm{Ra}, \mathrm{S}, \mathrm{S}_{0}$ & BakiRci [83] \\
\hline Group 1 & S18 & $\mathrm{Rs} / \mathrm{Ra}=\mathrm{a}+\mathrm{b}_{1} \mathrm{~S} / \mathrm{S}_{0}+\mathrm{b}_{2} \log \left(\mathrm{S} / \mathrm{S}_{0}\right)$ & $\mathrm{Ra}, \mathrm{S}, \mathrm{S}_{0}$ & Newland [117] \\
\hline Group 1 & S19 & $\mathrm{Rs} / \mathrm{Ra}=\mathrm{a}+\mathrm{b}_{1} \mathrm{~S} / \mathrm{S}_{0}+\mathrm{b}_{2}\left(\mathrm{~S} / \mathrm{S}_{0}\right)^{2}$ & $\mathrm{Ra}, \mathrm{S}, \mathrm{S}_{0}$ & Ögelman et al [33] \\
\hline Group 1 & $\mathrm{~S} 20$ & $\mathrm{Rs} / \mathrm{Ra}=\mathrm{a}+\mathrm{b}_{1} \mathrm{~S} / \mathrm{Sn}+\mathrm{b}_{2}(\mathrm{~S} / \mathrm{Sn})^{2}$ & $\mathrm{Ra}, \mathrm{S}, \mathrm{S}_{0}$ & Togrul and Togrul $[84]$ \\
\hline
\end{tabular}




\begin{tabular}{|c|c|c|c|c|}
\hline Group 1 & $\mathrm{~S} 21$ & $\mathrm{Rs} / \mathrm{Ra}=\mathrm{a}+\mathrm{b}_{1} \ln \left(\mathrm{S} / \mathrm{S}_{0}\right)+\left(\mathrm{b}_{2}+\mathrm{b}_{3} \ln \left(\mathrm{S} / \mathrm{S}_{0}\right)\right) \mathrm{S} / \mathrm{S}_{0}$ & $\mathrm{Ra}, \mathrm{S}, \mathrm{S}_{0}$ & Togrul and Togrul $[84]$ \\
\hline Group 1 & $\mathrm{~S} 22$ & $\mathrm{Rs} / \mathrm{Ra}=\mathrm{a}+\mathrm{b}_{1} \mathrm{~S} / \mathrm{S}_{0}+\mathrm{b}_{2}\left(\mathrm{~S} / \mathrm{S}_{0}\right)^{2}+\mathrm{b}_{3}\left(\mathrm{~S} / \mathrm{S}_{0}\right)^{3}$ & $\mathrm{Ra}, \mathrm{S}, \mathrm{S}_{0}$ & Bahel et al [34] \\
\hline Group 1 & $\mathrm{~S} 23$ & $\mathrm{Rs} / \mathrm{Ra}=\mathrm{a}+\mathrm{b}_{1} \mathrm{~S} / \mathrm{Sn}+\mathrm{b}_{2}(\mathrm{~S} / \mathrm{Sn})^{2}+\mathrm{b}_{3}(\mathrm{~S} / \mathrm{Sn})^{3}$ & $\mathrm{Ra}, \mathrm{S}, \mathrm{S}_{0}$ & Togrul and Togrul $[84]$ \\
\hline Group 1 & $\mathrm{~S} 24$ & $\mathrm{Rs} / \mathrm{Ra}=\mathrm{a}+\mathrm{b}_{1} \mathrm{~S} / \mathrm{S}_{0}+\mathrm{b}_{2}\left(\mathrm{~S} / \mathrm{S}_{0}\right)^{2}+\mathrm{b}_{3}\left(\mathrm{~S} / \mathrm{S}_{0}\right)^{3}+\mathrm{b}_{4}\left(\mathrm{~S} / \mathrm{S}_{0}\right)^{4}$ & $\mathrm{Ra}, \mathrm{S}, \mathrm{S}_{0}$ & Togrul and Togrul $[84]$ \\
\hline Group 1 & $\mathrm{~S} 25$ & $\begin{array}{l}\mathrm{Rs} / \mathrm{Ra}=\mathrm{a}+\mathrm{b}_{1} \cos \left(\mathrm{S} / \mathrm{S}_{0}\right)+\mathrm{b}_{2} \sin \left(\mathrm{S} / \mathrm{S}_{0}\right)+\mathrm{b}_{3} \cos \left(2 \mathrm{~S} / \mathrm{S}_{0}\right)+ \\
\mathrm{b}_{4} \sin \left(2 \mathrm{~S} / \mathrm{S}_{0}\right)\end{array}$ & $\mathrm{Ra}, \mathrm{S}, \mathrm{S}_{0}$ & Behrang et al [82] \\
\hline Group 1 & S26 & $\begin{array}{l}\mathrm{Rs} / \mathrm{Ra}=\mathrm{a}+\mathrm{b}_{1} \mathrm{~S} / \mathrm{S}_{0}+\mathrm{b}_{2}\left(\mathrm{~S} / \mathrm{S}_{0}\right)^{2}+\mathrm{b}_{3}\left(\mathrm{~S} / \mathrm{S}_{0}\right)^{3}+\mathrm{b}_{4}\left(\mathrm{~S} / \mathrm{S}_{0}\right)^{4}+ \\
\mathrm{b}_{5}\left(\mathrm{~S} / \mathrm{S}_{0}\right)^{5}\end{array}$ & $\mathrm{Ra}, \mathrm{S}, \mathrm{S}_{0}$ & BakirciK [118] \\
\hline Group 1 & S27 & $\begin{array}{l}\mathrm{Rs} / \mathrm{Ra}=\mathrm{a}+\mathrm{b}_{1} \mathrm{~S} / \mathrm{S}_{0}+\mathrm{b}_{2}\left(\mathrm{~S} / \mathrm{S}_{0}\right)^{2}+\mathrm{b}_{3}\left(\mathrm{~S} / \mathrm{S}_{0}\right)^{3}+\mathrm{b}_{4}\left(\mathrm{~S} / \mathrm{S}_{0}\right)^{4}+ \\
\mathrm{b}_{5}\left(\mathrm{~S} / \mathrm{S}_{0}\right)^{5}+\mathrm{b}_{6}\left(\mathrm{~S} / \mathrm{S}_{0}\right)^{6}\end{array}$ & $\mathrm{Ra}, \mathrm{S}, \mathrm{S}_{0}$ & Katiyar et al [81] \\
\hline Group 1 & $\mathrm{~S} 28$ & $\begin{array}{l}\mathrm{Rs} / \mathrm{Ra}=\mathrm{a}+\mathrm{b}_{1} \cos \left(\mathrm{S} / \mathrm{S}_{0}\right)+\mathrm{b}_{2} \sin \left(\mathrm{S} / \mathrm{S}_{0}\right)+\mathrm{b}_{3} \cos \left(2 \mathrm{~S} / \mathrm{S}_{0}\right)+ \\
\mathrm{b}_{4} \sin 2\left(\mathrm{~S} / \mathrm{S}_{0}\right)+\mathrm{b}_{5} \cos \left(3 \mathrm{~S} / \mathrm{S}_{0}\right)+\mathrm{b}_{6} \sin \left(3 \mathrm{~S} / \mathrm{S}_{0}\right)\end{array}$ & $\mathrm{Ra}, \mathrm{S}, \mathrm{S}_{0}$ & Behrang et al [82] \\
\hline Group 2 & ST1 & $\mathrm{Rs}=\mathrm{a}+\mathrm{b}_{1} \mathrm{~S}+\mathrm{c}_{1} \mathrm{~T}$ & $\mathrm{~S}, \mathrm{~T}$ & $\mathrm{Pu}[91]$ \\
\hline Group 2 & ST2 & $\mathrm{Rs} / \mathrm{Ra}=\mathrm{a}+\mathrm{b}_{1} \mathrm{~S} / \mathrm{S}_{0}+\mathrm{c}_{1} \mathrm{~T}$ & $\mathrm{Ra}, \mathrm{S}, \mathrm{S}_{0}, \mathrm{~T}$ & Falayi et al [85] \\
\hline Group 2 & ST3 & $\mathrm{Rs} / \mathrm{Ra}=\mathrm{a}+\mathrm{b}_{1} \mathrm{~S} / \mathrm{S}_{0}+\mathrm{c}_{1} \mathrm{Tmin}$ & $\mathrm{Ra}, \mathrm{S}, \mathrm{S}_{0}, \mathrm{Tmin}$ & Falayi et al [85] \\
\hline Group 2 & ST4 & $\mathrm{Rs} / \mathrm{Ra}=\mathrm{a}+\mathrm{b}_{1} \mathrm{~S} / \mathrm{S}_{0}+\mathrm{c}_{1} \mathrm{Tmax}$ & $\mathrm{Ra}, \mathrm{S}, \mathrm{S}_{0}, \mathrm{Tmax}$ & Olayinka [86] \\
\hline Group 2 & ST5 & $\mathrm{Rs} / \mathrm{Ra}=\mathrm{a}+\mathrm{b}_{1} \mathrm{~S} / \mathrm{S}_{0}+\mathrm{c}_{1}(\operatorname{Tmax} / 65)$ & $\mathrm{Ra}, \mathrm{S}, \mathrm{S}_{0}, \mathrm{Tmax}$ & Mubiru et al [111] \\
\hline Group 2 & ST6 & $\mathrm{Rs} / \mathrm{Ra}=\mathrm{a}+\mathrm{b}_{1} \mathrm{~S} / \mathrm{S}_{0}+\mathrm{c}_{1} \mathrm{Tmin} / \mathrm{Tmax}$ & $\mathrm{Ra}, \mathrm{S}, \mathrm{S}_{0}, \mathrm{Tmax}, \mathrm{Tmin}$ & Falayi et al [85] \\
\hline Group 2 & ST7 & $\mathrm{Rs} / \mathrm{Ra}=\mathrm{a}+\mathrm{b}_{1} \mathrm{~S} / \mathrm{S}_{0}+\mathrm{c}_{1} \mathrm{~T}(\mathrm{Tmin} / \mathrm{Tmax})$ & $\mathrm{Ra}, \mathrm{S}, \mathrm{S}_{0}, \mathrm{Tmax}, \mathrm{Tmin}, \mathrm{T}$ & Sambo [119] \\
\hline Group 2 & ST8 & $\mathrm{Rs}=\mathrm{a}+\mathrm{a}_{1} \mathrm{Ra}+\mathrm{b}_{1} \mathrm{~S} / \mathrm{S}_{0}+\mathrm{c}_{1} \mathrm{Tmax}$ & $\mathrm{Ra}, \mathrm{S}, \mathrm{S}_{0}, \mathrm{Tmax}$ & Saffaripour et al [42] \\
\hline Group 2 & ST9 & $\mathrm{Rs} / \mathrm{Ra}=\mathrm{a}+\mathrm{b}_{1} \mathrm{~S} / \mathrm{S}_{0}+\mathrm{c}_{1} \mathrm{Tmin}+\mathrm{c}_{2} \mathrm{Tmax}$ & $\mathrm{Ra}, \mathrm{S}, \mathrm{S}_{0}, \mathrm{Tmax}, \mathrm{Tmin}$ & Chen and $\mathrm{Li}[20]$ \\
\hline Group 2 & ST10 & $\mathrm{Rs} / \mathrm{Ra}=\mathrm{a}+\mathrm{b}_{1} \mathrm{~S} / \mathrm{S}_{0}+\mathrm{c}_{1} \mathrm{~T}+\mathrm{c}_{2} \mathrm{Tmin} / \mathrm{Tmax}$ & $\mathrm{Ra}, \mathrm{S}, \mathrm{S}_{0}, \mathrm{Tmax}, \mathrm{Tmin}, \mathrm{T}$ & Falayi et al [85] \\
\hline Group 2 & ST11 & $\mathrm{Rs} / \mathrm{Ra}=\mathrm{a}+\mathrm{b}_{1}\left(\triangle \mathrm{T} / \mathrm{S}_{0}\right)$ & $\mathrm{Ra}, \mathrm{S}_{0}, \mathrm{Tmax}, \mathrm{Tmin}$ & Garcia [88] \\
\hline Group 2 & ST12 & $\mathrm{Rs} / \mathrm{Ra}=\mathrm{a}+\exp \left(\mathrm{b}_{1} \triangle \mathrm{T} / \mathrm{S}_{0}\right)$ & $\mathrm{Ra}, \mathrm{S}_{0}, \mathrm{Tmax}, \mathrm{Tmin}$ & Garcia [88] \\
\hline Group 2 & ST13 & $\mathrm{Rs} / \mathrm{Ra}=\mathrm{a}+\mathrm{b}_{1} \log \left(\triangle \mathrm{T} / \mathrm{S}_{0}\right)$ & $\mathrm{Ra}, \mathrm{S}_{0}, \mathrm{Tmax}, \mathrm{Tmin}$ & Garcia [88] \\
\hline
\end{tabular}




\begin{tabular}{|c|c|c|c|c|}
\hline Group 2 & ST14 & $\mathrm{Rs} / \mathrm{Ra}=\mathrm{b}_{1}\left(1-\exp \left(\mathrm{d}_{2}(\triangle \mathrm{T})^{\mathrm{cl}} / \mathrm{S}_{0}\right)\right)$ & $\mathrm{Ra}, \mathrm{S}_{0}, \mathrm{Tmax}, \mathrm{Tmin}$ & Donatelli and Marletto [89] \\
\hline Group 2 & ST15 & $\mathrm{Rs} / \mathrm{Ra}=0.75\left(1-\exp \left(\mathrm{b}_{1}(\triangle \mathrm{T})^{2} / \mathrm{S}_{0}\right)\right)$ & $\mathrm{Ra}, \mathrm{S}_{0}, \mathrm{Tmax}, \mathrm{Tmin}$ & Weiss et al [87] \\
\hline Group 2 & ST16 & $\mathrm{Rs} / \mathrm{Ra}=\mathrm{a}+\mathrm{b}_{1} \mathrm{~S} / \mathrm{S}_{0}+\mathrm{c}_{1} \triangle \mathrm{T}$ & $\mathrm{Ra}, \mathrm{S}, \mathrm{S}_{0}, \mathrm{Tmax}, \mathrm{Tmin}$ & Abdallah [120] \\
\hline Group 2 & ST17 & $\mathrm{Rs} / \mathrm{Ra}=\mathrm{a}+\mathrm{b}_{1} \mathrm{~S} / \mathrm{S}_{0}+\mathrm{c}_{1}(\triangle \mathrm{T})^{0.5}$ & $\mathrm{Ra}, \mathrm{S}, \mathrm{S}_{0}, \mathrm{Tmax}, \mathrm{Tmin}$ & Chen and $\mathrm{Li}[20]$ \\
\hline Group 2 & ST18 & $\mathrm{Rs} / \mathrm{Ra}=\mathrm{a}+\mathrm{b}_{1}\left(\mathrm{~S} / \mathrm{S}_{0}\right)^{\mathrm{b} 2}+\mathrm{c}_{1} \ln (\triangle \mathrm{T})$ & $\mathrm{Ra}, \mathrm{S}, \mathrm{S}_{0}, \mathrm{Tmax}, \mathrm{Tmin}$ & Chen et al [121] \\
\hline Group 2 & ST19 & $\mathrm{Rs} / \mathrm{Ra}=\mathrm{a}+\mathrm{b}_{1}\left(\mathrm{~S} / \mathrm{S}_{0}\right)^{\mathrm{b} 2}+\mathrm{c}_{1}(\triangle \mathrm{T})^{\mathrm{c} 2}$ & $\mathrm{Ra}, \mathrm{S}, \mathrm{S}_{0}, \mathrm{Tmax}, \mathrm{Tmin}$ & Khil-Ha Lee [41] \\
\hline Group 2 & ST20 & $\mathrm{Rs} / \mathrm{Ra}=\mathrm{a}+\mathrm{b}_{1}\left(\triangle \mathrm{T} / \mathrm{S}_{0}\right)+\mathrm{b}_{2}\left(\triangle \mathrm{T} / \mathrm{S}_{0}\right)^{2}$ & $\mathrm{Ra}, \mathrm{S}, \mathrm{S}_{0}, \mathrm{Tmax}, \mathrm{Tmin}$ & Garcia $[88]$ \\
\hline Group 2 & ST21 & $\mathrm{Rs} / \mathrm{Ra}=\mathrm{a}+\mathrm{b}_{1}\left(\triangle \mathrm{T} / \mathrm{S}_{0}\right)+\mathrm{b}_{2}\left(\triangle \mathrm{T} / \mathrm{S}_{0}\right)^{2}+\mathrm{b}_{3}\left(\triangle \mathrm{T} / \mathrm{S}_{0}\right)^{3}$ & $\mathrm{Ra}, \mathrm{S}, \mathrm{S}_{0}, \mathrm{Tmax}, \mathrm{Tmin}$ & Garcia $[88]$ \\
\hline Group 3 & SR1 & $\mathrm{Rs}=\mathrm{b}_{1}(\mathrm{~S})^{\mathrm{b} 2}(\mathrm{Rh})^{\mathrm{d} 1}$ & $\mathrm{~S}, \mathrm{Rh}$ & Lewis [90] \\
\hline Group 3 & $\mathrm{SR} 2$ & $\mathrm{Rs}=\mathrm{b}_{1}\left(\mathrm{~S} / \mathrm{S}_{0}\right)^{\mathrm{b} 2}(\mathrm{Rh})^{\mathrm{d} 1}$ & $\mathrm{~S}, \mathrm{~S}_{0}, \mathrm{Rh}$ & Lewis [90] \\
\hline Group 3 & SR3 & $\mathrm{Rs}=\mathrm{a}+\mathrm{b}_{1}(\mathrm{Rh}-\mathrm{S})$ & $\mathrm{S}, \mathrm{Rh}$ & Elagib et al [121] \\
\hline Group 3 & SR4 & $\mathrm{Rs}=\mathrm{a}+\mathrm{b}_{1} \mathrm{~S} / \mathrm{S}_{0}+\mathrm{d}_{1} \mathrm{Rh}$ & $\mathrm{S}, \mathrm{S}_{0}, \mathrm{Rh}$ & Lewis [90] \\
\hline Group 3 & SR5 & $\mathrm{Rs} / \mathrm{Ra}=\mathrm{a}+\mathrm{b}_{1} \mathrm{~S} / \mathrm{S}_{0}+\mathrm{d}_{1} \mathrm{Rh}$ & $\mathrm{Ra}, \mathrm{S}, \mathrm{S}_{0}, \mathrm{Rh}$ & Swartman and Ogunlade [123] \\
\hline Group 3 & SR6 & $R s=a+a_{1} R a+b_{1} S / S_{0}+d_{1} R h$ & $\mathrm{Ra}, \mathrm{S}, \mathrm{S}_{0}, \mathrm{Rh}$ & Saffaripour et al [42] \\
\hline Group 3 & SR7 & $\mathrm{Rs} / \mathrm{Ra}=\mathrm{a}+\mathrm{b}_{1} \mathrm{~S} / \mathrm{S}_{0}+\mathrm{b}_{2}\left(\mathrm{~S} / \mathrm{S}_{0}\right)^{2}+\mathrm{d}_{1} \mathrm{Rh}$ & $\mathrm{Ra}, \mathrm{S}, \mathrm{S}_{0}, \mathrm{Rh}$ & Bakirci Kadir [43] \\
\hline Group 3 & SR8 & $\mathrm{Rs} / \mathrm{Ra}=\mathrm{a}+\mathrm{b}_{1} \mathrm{~S} / \mathrm{S}_{0}+\mathrm{b}_{2}\left(\mathrm{~S} / \mathrm{S}_{0}\right)^{2}+\mathrm{b}_{3}\left(\mathrm{~S} / \mathrm{S}_{0}\right)^{3}+\mathrm{d}_{1} \mathrm{Rh}$ & $\mathrm{Ra}, \mathrm{S}, \mathrm{S}_{0}, \mathrm{Rh}$ & Yildırım et al [13] \\
\hline Group 4 & SP1 & $\mathrm{Rs} / \mathrm{Ra}=\mathrm{a}+\mathrm{b}_{1} \mathrm{~S} / \mathrm{S}_{0}+\mathrm{e}_{1} \mathrm{P}$ & $\mathrm{Ra}, \mathrm{S}, \mathrm{S}_{0}, \mathrm{P}$ & Chen and Li [20] \\
\hline Group 5 & SPr1 & $\mathrm{Rs} / \mathrm{Ra}=\mathrm{a}+\mathrm{b}_{1} \mathrm{~S} / \mathrm{S}_{0}+\mathrm{f}_{1} \mathrm{Ap}$ & $\mathrm{Ra}, \mathrm{S}, \mathrm{S}_{0}, \mathrm{Ap}$ & Chen and Li [20] \\
\hline Group 5 & SPr2 & $R s=a+b_{1} S+f_{1} V p$ & $\mathrm{~S}, \mathrm{~S}_{0}, \mathrm{Vp}$ & $\mathrm{Pu}[91]$ \\
\hline Group 5 & $\mathrm{SPr} 3$ & $\mathrm{Rs} / \mathrm{Ra}=\mathrm{a}+\left(\mathrm{a}_{1}+\mathrm{f}_{1} \mathrm{Vp}\right) \mathrm{S} / \mathrm{S}_{0}$ & $\mathrm{Ra}, \mathrm{S}, \mathrm{S}_{0}, \mathrm{Vp}$ & Liu et al [44] \\
\hline Group 6 & SG1 & $\mathrm{Rs} / \mathrm{Ra}=\mathrm{e}^{\mathrm{a} 1}\left(\mathrm{~S} / \mathrm{S}_{0}\right)^{\mathrm{b} 1}(\sin (90-\delta-\varphi))^{\mathrm{g} 1}$ & $\mathrm{Ra}, \mathrm{S}, \mathrm{S}_{0}, \varphi, \delta$ & Coppolino [115] \\
\hline Group 6 & SG2 & $\mathrm{Rs} / \mathrm{Ra}=\mathrm{b}_{1} \mathrm{~S} / \mathrm{S}_{0}+\mathrm{g}_{1} \cos \varphi$ & $\mathrm{Ra}, \mathrm{S}, \mathrm{S}_{0}, \varphi$ & Glower and McGulloch [124] \\
\hline Group 6 & SG3 & $\begin{array}{l}\mathrm{Rs} / \mathrm{Ra}=\mathrm{a}+\mathrm{b}_{1} \mathrm{~S} / \mathrm{S}_{04} \\
\mathrm{~S}_{04}=2 / 15 \cos ^{-1}\left(\left(\sin 4^{\circ}-\sin \varphi \sin \delta\right) / \cos \varphi \cos \delta\right)\end{array}$ & $\mathrm{Ra}, \mathrm{S}, \varphi, \delta$ & Bennett [125] \\
\hline
\end{tabular}




\begin{tabular}{|c|c|c|c|c|}
\hline Group 6 & SG4 & $\mathrm{Rs} / \mathrm{Ra}=\mathrm{a}+\mathrm{b}_{1} \mathrm{~S} / \mathrm{S}_{0}+\mathrm{g}_{1} \varphi$ & $\mathrm{Ra}, \mathrm{S}, \mathrm{S}_{0}, \varphi$ & Elagib and Mansell [92] \\
\hline Group 6 & SG5 & $\mathrm{Rs} / \mathrm{Ra}=\mathrm{a}+\mathrm{b}_{1} \mathrm{~S} / \mathrm{S}_{0}+\mathrm{g}_{1} \mathrm{Z}$ & $\mathrm{Ra}, \mathrm{S}, \mathrm{S}_{0}, \mathrm{Z}$ & Elagib and Mansell [92] \\
\hline Group 6 & SG6 & $\mathrm{Rs} / \mathrm{Ra}=\mathrm{a}+\mathrm{b}_{1} \mathrm{~S} / \mathrm{S}_{0}+\mathrm{g}_{1} \sin (\delta)$ & $\mathrm{Ra}, \mathrm{S}, \mathrm{S}_{0}, \delta$ & Togrul and Togrul $[84]$ \\
\hline Group 6 & SG7 & $\mathrm{Rs}=\mathrm{b}_{1} \mathrm{~S}^{1.24} \delta^{-0.19}+\mathrm{g}_{1}(\sin \delta)^{2.1}+\mathrm{g}_{2}(\sin \delta)^{3}$ & $\mathrm{~S}, \delta$ & Barbaro et al [125] \\
\hline Group 6 & SG8 & $\mathrm{Rs} / \mathrm{Ra}=\mathrm{a}+\mathrm{b}_{1} \mathrm{~S} / \mathrm{S}_{0}+\mathrm{g}_{1} \varphi+\mathrm{g}_{2} \mathrm{Z}$ & $\mathrm{Ra}, \mathrm{S}, \mathrm{S}_{0}, \varphi, \mathrm{Z}$ & Elagib and Mansell [92] \\
\hline Group 6 & SG9 & $\mathrm{Rs} / \mathrm{Ra}=\mathrm{a}+\mathrm{b}_{1} \mathrm{~S} / \mathrm{S}_{0}+\mathrm{g}_{1} \cos \varphi+\mathrm{g}_{2} \mathrm{Z}$ & $\mathrm{Ra}, \mathrm{S}, \mathrm{S}_{0}, \varphi, \mathrm{Z}$ & Elagib and Mansell [92] \\
\hline Group 6 & SG10 & $\mathrm{Rs} / \mathrm{Ra}=\mathrm{a}+\left(\mathrm{a}_{1}+\mathrm{g}_{1} \varphi\right) \mathrm{S} / \mathrm{S}_{0}+\mathrm{g}_{2} \varphi$ & $\mathrm{Ra}, \mathrm{S}, \mathrm{S}_{0}, \varphi$ & Dogniaux Lemoine [127] \\
\hline Group 6 & SG11 & $\mathrm{Rs} / \mathrm{Ra}=\mathrm{a}+\left(\mathrm{a}_{1}+\mathrm{g}_{1} \cos (\varphi-\delta)\right) \mathrm{S} / \mathrm{S}_{0}+\mathrm{g}_{2} \cos (\varphi-\delta)+\mathrm{g}_{3} \mathrm{Z}$ & $\mathrm{Ra}, \mathrm{S}, \mathrm{S}_{0}, \mathrm{Z}, \varphi, \lambda$ & Kilic and Ozturk [128] \\
\hline Group 6 & SG12 & $\mathrm{Rs} / \mathrm{Ra}=\mathrm{a}+\mathrm{b}_{1} \mathrm{~S} / \mathrm{S}_{0}+\mathrm{g}_{1} \cos \varphi+\mathrm{g}_{2} \cos \lambda+\mathrm{g}_{3} \mathrm{Z}$ & $\mathrm{Ra}, \mathrm{S}, \mathrm{S}_{0}, \mathrm{Z}, \varphi, \lambda$ & Rehman [129] \\
\hline Group 6 & SG13 & $\mathrm{Rs} / \mathrm{Ra}=\mathrm{a}+\mathrm{b}_{1} \mathrm{~S} / \mathrm{S}_{0}+\mathrm{g}_{1} \varphi+\mathrm{g}_{2} \lambda+\mathrm{g}_{3} \mathrm{Z}$ & $\mathrm{Ra}, \mathrm{S}, \mathrm{S}_{0}, \mathrm{Z}, \varphi, \lambda$ & Chen et al [93] \\
\hline Group 6 & SG14 & $\mathrm{Rs} / \mathrm{Ra}=\mathrm{a}+\mathrm{b}_{1} \mathrm{~S} / \mathrm{S}_{0}+\mathrm{g}_{1} \cos \varphi+\mathrm{g}_{2} \lambda+\mathrm{g}_{3} \mathrm{Z}$ & $\mathrm{Ra}, \mathrm{S}, \mathrm{S}_{0}, \mathrm{Z}, \varphi, \lambda$ & Chen et al [93] \\
\hline Group 6 & SG15 & $\mathrm{Rs} / \mathrm{Ra}=\mathrm{a}+\mathrm{b}_{1} \mathrm{~S} / \mathrm{S}_{0}+\mathrm{b}_{2} \mathrm{Z}\left(\mathrm{S} / \mathrm{S}_{0}\right)+\mathrm{b}_{3}\left(\mathrm{~S} / \mathrm{S}_{0}\right)^{2}+\mathrm{g}_{1} \mathrm{Z}$ & $\mathrm{Ra}, \mathrm{S}, \mathrm{S}_{0}, \mathrm{Z}$ & Gopinathan [130] \\
\hline Group 6 & SG16 & $\mathrm{Rs} / \mathrm{Ra}=\mathrm{a}+\mathrm{b}_{1} \mathrm{~S} / \mathrm{S}_{0}+\mathrm{b}_{2}\left(\mathrm{a}_{1}+\mathrm{S} / \mathrm{S}_{0}\right)\left(\mathrm{n}-\mathrm{a}_{2}\right)^{2}$ & $\mathrm{Ra}, \mathrm{S}, \mathrm{S}_{0}, \mathrm{n}$ & Klabzuba et al [131] \\
\hline Group 6 & SG17 & $\mathrm{Rs} / \mathrm{Ra}=\mathrm{a}+\left(\left(\mathrm{a}_{1}+\mathrm{g}_{1} \cos (\varphi-\delta)\right) \mathrm{S} / \mathrm{S}_{0}+\mathrm{g}_{2} \cos (\varphi-\delta)+\mathrm{g}_{3} \mathrm{Z}\right.$ & $\mathrm{Ra}, \mathrm{S}, \mathrm{S}_{0}, \mathrm{Z}, \varphi$ & Kilic and Ozturk [125] \\
\hline Group 6 & SG18 & $\mathrm{Rs} / \mathrm{Ra}=\mathrm{a}+\left(\mathrm{a}_{1}+\mathrm{g}_{1} \varphi+\mathrm{g}_{2} \mathrm{Z}\right) \mathrm{S} / \mathrm{S}_{0}+\mathrm{g}_{3} \varphi+\mathrm{g}_{4} \mathrm{Z}$ & $\mathrm{Ra}, \mathrm{S}, \mathrm{S}_{0}, \mathrm{Z}, \varphi$ & Jin et al [94] \\
\hline Group 6 & SG19 & $\mathrm{Rs} / \mathrm{Ra}=\mathrm{a}+\left(\mathrm{a}_{1}+\mathrm{g}_{1} \cos \varphi+\mathrm{g}_{2} \mathrm{Z}\right) \mathrm{S} / \mathrm{S}_{0}+\mathrm{g}_{3} \cos \varphi+\mathrm{g}_{4} \mathrm{Z}$ & $\mathrm{Ra}, \mathrm{S}, \mathrm{S}_{0}, \mathrm{Z}, \varphi$ & Jin et al [94] \\
\hline Group 6 & SG20 & $\mathrm{Rs} / \mathrm{Ra}=\mathrm{a}+\mathrm{b}_{1} \mathrm{~S} / \mathrm{S}_{0}+\mathrm{b}_{2}\left(\mathrm{~S} / \mathrm{S}_{0}\right)^{2}+\mathrm{b}_{3}\left(\mathrm{~S} / \mathrm{S}_{0}\right)^{3}+\mathrm{g}_{1} \varphi+\mathrm{g}_{2} \mathrm{Z}$ & $\mathrm{Ra}, \mathrm{S}, \mathrm{S}_{0}, \mathrm{Z}, \varphi$ & Chen et al [93] \\
\hline Group 6 & $\mathrm{SG} 21$ & $\mathrm{Rs} / \mathrm{Ra}=\mathrm{a}+\mathrm{b}_{1} \mathrm{~S} / \mathrm{S}_{0}+\mathrm{b}_{2}\left(\mathrm{~S} / \mathrm{S}_{0}\right)^{2}+\mathrm{b}_{3}\left(\mathrm{~S} / \mathrm{S}_{0}\right)^{3}+\mathrm{g}_{1} \cos \varphi+\mathrm{g}_{2} \mathrm{Z}$ & $\mathrm{Ra}, \mathrm{S}, \mathrm{S}_{0}, \mathrm{Z}, \varphi$ & Chen et al [93] \\
\hline Group 6 & SG22 & $\begin{array}{l}\mathrm{Rs} / \mathrm{Ra}=\mathrm{a}+\mathrm{b}_{1} \mathrm{~S} / \mathrm{S}_{0}+\mathrm{b}_{2} \mathrm{~S} / \mathrm{S}_{0}(\cos \varphi)+\mathrm{b}_{3} \mathrm{Z}\left(\mathrm{S} / \mathrm{S}_{0}\right)+\mathrm{b}_{4}\left(\mathrm{~S} / \mathrm{S}_{0}\right)^{2}+ \\
\mathrm{g}_{1} \cos \varphi+\mathrm{g}_{2} \mathrm{Z}\end{array}$ & $\mathrm{Ra}, \mathrm{S}, \mathrm{S}_{0}, \mathrm{Z}, \varphi$ & Gopinathan [130] \\
\hline Group 6 & $\mathrm{SG} 23$ & $\mathrm{Rs} / \mathrm{Ra}=\mathrm{a}+\left(\mathrm{a}_{1}+\mathrm{g}_{1} \varphi+\mathrm{g}_{2} \lambda+\mathrm{g}_{3} \mathrm{Z}\right) \mathrm{S} / \mathrm{S}_{0}+\mathrm{g}_{4} \varphi+\mathrm{g}_{5} \lambda+\mathrm{g}_{6} \mathrm{Z}$ & $\mathrm{Ra}, \mathrm{S}, \mathrm{S}_{0}, \mathrm{Z}, \varphi, \lambda$ & Chen et al [93] \\
\hline Group 6 & SG24 & $\begin{array}{l}\mathrm{Rs} / \mathrm{Ra}=\mathrm{a}+\left(\mathrm{a}_{1}+\mathrm{g}_{1} \cos \varphi+\mathrm{g}_{2} \lambda+\mathrm{g}_{3} \mathrm{Z}\right) \mathrm{S} / \mathrm{S}_{0}+\mathrm{g}_{4} \cos \varphi+\mathrm{g}_{5} \lambda+ \\
\mathrm{g}_{6} \mathrm{Z}\end{array}$ & $\mathrm{Ra}, \mathrm{S}, \mathrm{S}_{0}, \mathrm{Z}, \varphi, \lambda$ & Chen et al [93] \\
\hline Group 6 & SG25 & $\begin{array}{l}\mathrm{Rs} / \mathrm{Ra}=\mathrm{a}+\mathrm{b}_{1} \mathrm{~S} / \mathrm{S}_{0}+\mathrm{b}_{2}\left(\mathrm{~S} / \mathrm{S}_{0}\right)^{2}+\mathrm{b}_{3}\left(\mathrm{~S} / \mathrm{S}_{0}\right)^{3}+\mathrm{g}_{1} \varphi+\mathrm{g}_{2} \lambda+\mathrm{g}_{3} \lambda^{2}+ \\
\mathrm{g}_{4} \mathrm{Z}\end{array}$ & $\mathrm{Ra}, \mathrm{S}, \mathrm{S}_{0}, \mathrm{Z}, \varphi, \lambda$ & Chen et al [93] \\
\hline
\end{tabular}




\begin{tabular}{|c|c|c|c|c|}
\hline Group 6 & SG26 & $\begin{array}{l}\mathrm{Rs} / \mathrm{Ra}=\mathrm{a}+\mathrm{b}_{1} \mathrm{~S} / \mathrm{S}_{0}+\mathrm{b}_{2}\left(\mathrm{~S} / \mathrm{S}_{0}\right)^{2}+\mathrm{b}_{3}\left(\mathrm{~S} / \mathrm{S}_{0}\right)^{3}+\mathrm{g}_{1} \cos \varphi^{+} \mathrm{g}_{2} \lambda+ \\
\mathrm{g}_{3} \lambda^{2}+\mathrm{g}_{4} \mathrm{Z}\end{array}$ & $\mathrm{Ra}, \mathrm{S}, \mathrm{S}_{0}, \mathrm{Z}, \varphi, \lambda$ & Chen et al [93] \\
\hline Group 6 & SG27 & $\begin{array}{l}\mathrm{Rs} / \mathrm{Ra}=\mathrm{a}+\left(\mathrm{a}_{1}+\mathrm{g}_{1} \varphi+\mathrm{g}_{2} \mathrm{Z}\right) \mathrm{S} / \mathrm{S}_{0}+\left(\mathrm{a}_{2}+\mathrm{g}_{3} \varphi+\mathrm{g}_{4} \mathrm{Z}\right)\left(\mathrm{S} / \mathrm{S}_{0}\right)^{2}+ \\
\mathrm{g}_{5} \varphi+\mathrm{g}_{6} \mathrm{Z}\end{array}$ & $\mathrm{Ra}, \mathrm{S}, \mathrm{S}_{0}, \mathrm{Z}, \varphi$ & Jin et al[94] \\
\hline Group 6 & SG28 & $\begin{array}{l}\mathrm{Rs} / \mathrm{Ra}=\mathrm{a}+\left(\mathrm{a}_{1}+\mathrm{g}_{1} \cos \varphi+\mathrm{g}_{2} \mathrm{Z}\right) \mathrm{S} / \mathrm{S}_{0}+\left(\mathrm{a}_{2}+\mathrm{g}_{3} \cos \varphi+\mathrm{g}_{4} \mathrm{Z}\right) \\
\left(\mathrm{S} / \mathrm{S}_{0}\right)^{2}+\mathrm{g}_{5} \cos \varphi+\mathrm{g}_{6} \mathrm{Z}\end{array}$ & $\mathrm{Ra}, \mathrm{S}, \mathrm{S}_{0}, \mathrm{Z}, \varphi$ & Jin et al [94] \\
\hline Group 6 & SG29 & $\begin{array}{l}\mathrm{Rs} / \mathrm{Ra}=\mathrm{a}+\left(\mathrm{a}_{1}+\mathrm{g}_{1} \cos \varphi+\mathrm{g}_{2} \mathrm{Z}\right) \mathrm{S} / \mathrm{S}_{0}+\left(\mathrm{a}_{2}+\mathrm{g}_{3} \cos \varphi+\right. \\
\left.\mathrm{g}_{4} \mathrm{Z}\right)\left(\mathrm{S} / \mathrm{S}_{0}\right)^{2}+\left(\mathrm{a}_{3}+\mathrm{g}_{5} \cos \varphi+\mathrm{g}_{6} \mathrm{Z}\right)\left(\mathrm{S} / \mathrm{S}_{0}\right)^{3}+\mathrm{g}_{7} \cos \varphi+\mathrm{g}_{8} \mathrm{Z}\end{array}$ & $\mathrm{Ra}, \mathrm{S}, \mathrm{S}_{0}, \mathrm{Z}, \varphi$ & Chen et al [93] \\
\hline Group 6 & SG30 & $\begin{array}{l}\mathrm{Rs} / \mathrm{Ra}=\mathrm{a}+\left(\mathrm{a}_{1}+\mathrm{g}_{1} \cos \varphi+\mathrm{g}_{2} \mathrm{Z}+\mathrm{g}_{3} \lambda+\mathrm{g}_{4} \lambda^{2}\right) \mathrm{S} / \mathrm{S}_{0}+\left(\mathrm{a}_{2}+\right. \\
\left.\mathrm{g}_{5} \cos \varphi+\mathrm{g}_{6} \mathrm{Z}+\mathrm{g}_{7} \lambda+\mathrm{g}_{8} \lambda^{2}\right)\left(\mathrm{S} / \mathrm{S}_{0}\right)^{2}+\left(\mathrm{a}_{3}+\mathrm{g}_{9} \cos \varphi+\mathrm{g}_{10} \mathrm{Z}+\mathrm{g}_{11} \lambda\right. \\
\left.+\mathrm{g}_{12} \lambda^{2}\right)\left(\mathrm{S} / \mathrm{S}_{0}\right)^{3}+\mathrm{g}_{13} \cos \varphi+\mathrm{g}_{14} \mathrm{Z}+\mathrm{g}_{15} \lambda+\mathrm{g}_{16} \lambda^{2}\end{array}$ & $\mathrm{Ra}, \mathrm{S}, \mathrm{S}_{0}, \mathrm{Z}, \varphi, \lambda$ & Chen et al [93] \\
\hline Group 7 & STR1 & $\mathrm{Rs} / \mathrm{Ra}=\mathrm{b}_{1}\left(\mathrm{~S} / \mathrm{S}_{0}\right)^{\mathrm{b} 2}(\mathrm{Tmax})^{\mathrm{c} 1}(\mathrm{Rh})^{\mathrm{d} 1}$ & $\mathrm{Ra}, \mathrm{S}, \mathrm{S}_{0}, \mathrm{Tmax}, \mathrm{Rh}$ & Ododo et al [98] \\
\hline Group 7 & STR2 & $\mathrm{Rs} / \mathrm{Ra}=\exp \left(\mathrm{b}_{1} \mathrm{~S} / \mathrm{S}_{0}-\mathrm{d}_{1} \mathrm{Rh}-\mathrm{c}_{1} / \mathrm{Tmax}\right)$ & $\mathrm{Ra}, \mathrm{S}, \mathrm{S}_{0}, \mathrm{Tmax}, \mathrm{Rh}$ & Onyango [132] \\
\hline Group 7 & STR3 & $\mathrm{Rs}=\mathrm{a}+\mathrm{b}_{1}(\mathrm{Rh}-\mathrm{T}-\mathrm{S})$ & $\mathrm{S}, \mathrm{T}, \mathrm{Rh}$ & Elagib et al [121] \\
\hline Group 7 & STR4 & $\begin{array}{l}\mathrm{Rs} / \mathrm{Ra}=\mathrm{a}+\mathrm{b}_{1} \mathrm{~S} / \mathrm{S}_{0}+\mathrm{d}_{1} \mathrm{Wa} 1 \\
\mathrm{Wa} 1=\mathrm{Rh}\left(4.7923+0.3647 \mathrm{~T}+0.0055 \mathrm{~T}^{2}+0.0003 \mathrm{~T}^{3}\right)\end{array}$ & $\mathrm{Ra}, \mathrm{S}, \mathrm{S}_{0}, \mathrm{~T}, \mathrm{Rh}$ & Garg and Garg [133] \\
\hline Group 7 & STR5 & $\begin{array}{l}\mathrm{Rs} / \mathrm{Ra}=\mathrm{a}+\mathrm{b}_{1} \mathrm{~S}+\mathrm{d}_{1} \mathrm{Wa} 2 \\
\mathrm{Wa} 2=0.0049 \mathrm{Rh}(\exp (26.23-5416 / \mathrm{T}) / \mathrm{T})\end{array}$ & $\mathrm{Ra}, \mathrm{S}, \mathrm{S}_{0}, \mathrm{~T}, \mathrm{Rh}$ & Garg and Garg [133] \\
\hline Group 7 & STR6 & $\mathrm{Rs}=\mathrm{a}+\mathrm{b}_{1} \mathrm{~S}+\mathrm{c}_{1} \mathrm{~T}+\mathrm{d}_{1} \mathrm{Rh}$ & $\mathrm{S}, \mathrm{T}, \mathrm{Rh}$ & Lin and Gao [134] \\
\hline Group 7 & STR7 & $\mathrm{Rs} / \mathrm{Ra}=\mathrm{a}+\mathrm{b}_{1} \mathrm{~S} / \mathrm{S}_{0}+\mathrm{c}_{1} \mathrm{~T}+\mathrm{d}_{1} \mathrm{Rh}$ & $\mathrm{Ra}, \mathrm{S}, \mathrm{S}_{0}, \mathrm{~T}, \mathrm{Rh}$ & Abdallah [120] \\
\hline Group 7 & STR8 & $\mathrm{Rs} / \mathrm{Ra}=\mathrm{a}+\mathrm{b}_{1} \mathrm{~S} / \mathrm{S}_{0}+\mathrm{c}_{1} \mathrm{Tmax}+\mathrm{d}_{1} \mathrm{Rh}$ & $\mathrm{Ra}, \mathrm{S}, \mathrm{S}_{0}, \mathrm{Tmax}, \mathrm{Rh}$ & Al-Salihi et al [97] \\
\hline Group 7 & STR9 & $\mathrm{Rs} / \mathrm{Ra}=\mathrm{a}+\mathrm{b}_{1} \mathrm{~S} / \mathrm{S}_{0}+\mathrm{c}_{1} \triangle \mathrm{T}+\mathrm{d}_{1} \mathrm{Rh}$ & $\mathrm{Ra}, \mathrm{S}, \mathrm{S}_{0}, \mathrm{Tmax}, \mathrm{Tmin}, \mathrm{Rh}$ & Abdalla [120] \\
\hline Group 7 & STR10 & $\mathrm{Rs}=\mathrm{a}+\mathrm{b}_{1} \mathrm{~S} / \mathrm{S}_{0}+\mathrm{c}_{1} \mathrm{~T} / \mathrm{Tmax}+\mathrm{d}_{1} \mathrm{Rh} / \mathrm{Rhmax}$ & $\mathrm{S}, \mathrm{S}_{0}, \mathrm{~T}, \mathrm{Tmax}, \mathrm{Rh}$ & Kuye and Jagtap [135] \\
\hline Group 7 & STR11 & $\mathrm{Rs} / \mathrm{Ra}=\mathrm{a}+\mathrm{b}_{1} \mathrm{~S} / \mathrm{S}_{0}+\mathrm{c}_{1} \mathrm{Tmin} / \mathrm{Tmax}+\mathrm{c}_{2} \mathrm{Rh} / \mathrm{Rhmax}$ & $\mathrm{Ra}, \mathrm{S}, \mathrm{S}_{0}, \mathrm{Tmax}, \mathrm{Tmin}, \mathrm{Rh}$ & Ojosu and Komolafe [136] \\
\hline Group 7 & STR12 & $\mathrm{Rs} / \mathrm{Ra}=\mathrm{a}+\mathrm{b}_{1} \mathrm{~S} / \mathrm{S}_{0}+\mathrm{c}_{1} \mathrm{Tmin} / \mathrm{Tmax}+\mathrm{d}_{1} \mathrm{Rh}$ & $\mathrm{Ra}, \mathrm{S}, \mathrm{S}_{0}, \mathrm{~T}, \mathrm{Tmax}, \mathrm{Rh}$ & Falayi et al [85] \\
\hline Group 7 & STR13 & $R s=a+a_{1} R a+b_{1} S / S_{0}+c_{1} T+d_{1} R h$ & $\mathrm{Ra}, \mathrm{S}, \mathrm{S}_{0}, \mathrm{~T}, \mathrm{Tmax}, \mathrm{Rh}$ & Thornton and Running [96] \\
\hline Group 7 & STR14 & $\mathrm{Rs} / \mathrm{Ra}=\mathrm{a}+\mathrm{b}_{1} \mathrm{~S} / \mathrm{S}_{0}+\mathrm{c}_{1} \mathrm{Tmin}+\mathrm{c}_{2} \mathrm{Tmax}+\mathrm{d}_{1} \mathrm{Rh}$ & $\mathrm{Ra}, \mathrm{S}, \mathrm{S}_{0}, \mathrm{Tmax}, \mathrm{Tmin}, \mathrm{Rh}$ & Chen and $\mathrm{Li}$ [20] \\
\hline
\end{tabular}




\begin{tabular}{|c|c|c|c|c|}
\hline Group 7 & STR15 & $\mathrm{Rs} / \mathrm{Ra}=\mathrm{a}+\mathrm{b}_{1} \mathrm{~S} / \mathrm{S}_{0}+\mathrm{c}_{1} \mathrm{~T}+\mathrm{c}_{2} \mathrm{Tmin} / \mathrm{Tmax}+\mathrm{d}_{1} \mathrm{Rh}$ & $\mathrm{Ra}, \mathrm{S}, \mathrm{S}_{0}, \mathrm{Tmax}, \mathrm{Tmin}, \mathrm{T}, \mathrm{Rh}$ & Falayi et al [85] \\
\hline Group 7 & STR16 & $\mathrm{Rs} / \mathrm{Ra}=\mathrm{a}+\mathrm{b}_{1} \mathrm{~S} / \mathrm{S}_{0}+\mathrm{c}_{1} \operatorname{Tmax}+\mathrm{b}_{2} \operatorname{Tmax}\left(\mathrm{S} / \mathrm{S}_{0}\right)+\mathrm{d}_{1} \mathrm{Rh}$ & $\mathrm{Ra}, \mathrm{S}, \mathrm{S}_{0}, \mathrm{Tmax}, \mathrm{Rh}$ & Ododo et al [98] \\
\hline Group 7 & STR17 & $\begin{array}{l}\mathrm{Rs} / \mathrm{Ra}=\mathrm{a}+\mathrm{b}_{1} \mathrm{~S} / \mathrm{S}_{0}+\mathrm{b}_{2}\left(\mathrm{~S} / \mathrm{S}_{0}-\mathrm{Rh}-\mathrm{Tmin} / \mathrm{Tmax}\right)+ \\
\mathrm{b}_{3}\left(\mathrm{~S} / \mathrm{S}_{0}\right)(\mathrm{Tmin} / \mathrm{Tmax})\end{array}$ & $\mathrm{Ra}, \mathrm{S}, \mathrm{S}_{0}, \mathrm{Tmax}, \mathrm{Tmin}, \mathrm{T}$ & Sambo [119] \\
\hline Group 8 & STP1 & $\mathrm{Rs} / \mathrm{Ra}=\mathrm{a}+\mathrm{b}_{1} \mathrm{~S} / \mathrm{S}_{0}+\mathrm{c}_{1} \mathrm{~T}+\mathrm{e}_{1} \mathrm{P}$ & $\mathrm{Ra}, \mathrm{S}, \mathrm{S}_{0}, \mathrm{~T}, \mathrm{P}$ & Chen et al [99] \\
\hline Group 8 & STP2 & $\mathrm{Rs} / \mathrm{Ra}=\mathrm{a}+\mathrm{b}_{1} \mathrm{~S} / \mathrm{S}_{0}+\mathrm{c}_{1} \operatorname{Tmin}+\mathrm{e}_{1} \mathrm{P}$ & $\mathrm{Ra}, \mathrm{S}, \mathrm{S}_{0}$, Tmin, $\mathrm{P}$ & Okonkwo and Nwokoye [46] \\
\hline Group 8 & STP3 & $\mathrm{Rs} / \mathrm{Ra}=\mathrm{a}+\mathrm{b}_{1} \mathrm{~S} / \mathrm{S}_{0}+\mathrm{c}_{1} \operatorname{Tmin}+\mathrm{c}_{2} \operatorname{Tmax}+\mathrm{e}_{1} \mathrm{P}$ & $\mathrm{Ra}, \mathrm{S}, \mathrm{S}_{0}, \mathrm{Tmax}, \mathrm{Tmin}, \mathrm{P}$ & Chen and $\mathrm{Li}[20]$ \\
\hline Group 8 & STP4 & $\mathrm{Rs} / \mathrm{Ra}=\mathrm{a}+\mathrm{b}_{1} \mathrm{~S} / \mathrm{S}_{0}+\mathrm{c}_{1} \ln \triangle \mathrm{T}+\mathrm{e}_{1} \ln (\mathrm{P}+1)$ & $\mathrm{Ra}, \mathrm{S}, \mathrm{S}_{0}, \mathrm{Tmax}, \mathrm{Tmin}, \mathrm{P}$ & Fan et al [45] \\
\hline Group 8 & STP5 & $\mathrm{Rs} / \mathrm{Ra}=\mathrm{a}+\mathrm{b}_{1} \mathrm{~S} / \mathrm{S}_{0}+\mathrm{c}_{1} \mathrm{~T}+\mathrm{c}_{2} \ln \triangle \mathrm{T}+\mathrm{e}_{1} \ln (\mathrm{P}+1)$ & $\mathrm{Ra}, \mathrm{S}, \mathrm{S}_{0}, \mathrm{Tmax}, \mathrm{Tmin}, \mathrm{T}, \mathrm{P}$ & Fan et al [45] \\
\hline Group 8 & STP6 & $\mathrm{Rs} / \mathrm{Ra}=\mathrm{a}+\mathrm{b}_{1}\left(\mathrm{~S} / \mathrm{S}_{0}\right)^{\mathrm{b} 2}+\mathrm{c}_{1} \mathrm{~T}+\mathrm{c}_{2} \ln \triangle \mathrm{T}+\mathrm{e}_{1} \ln (\mathrm{P}+1)$ & $\mathrm{Ra}, \mathrm{S}, \mathrm{S}_{0}, \mathrm{Tmax}, \mathrm{Tmin}, \mathrm{T}, \mathrm{P}$ & Fan et al [45] \\
\hline Group 8 & STP7 & $\mathrm{Rs} / \mathrm{Ra}=\mathrm{a}+\left(\mathrm{a}_{1}+\mathrm{c}_{1} \mathrm{~T}+\mathrm{e}_{1} \mathrm{P}\right) \mathrm{S} / \mathrm{S}_{0}+\mathrm{c}_{2} \mathrm{~T}+\mathrm{e}_{2} \mathrm{P}$ & $\mathrm{Ra}, \mathrm{S}, \mathrm{S}_{0}, \mathrm{~T}, \mathrm{P}$ & Chen et al [99] \\
\hline Group 8 & STP8 & $\mathrm{Rs} / \mathrm{Ra}=\mathrm{a}+\left(\mathrm{a}_{1}+\mathrm{c}_{1} \mathrm{~T}+\mathrm{e}_{1} \mathrm{P}+\mathrm{e}_{2} \mathrm{P}^{2}\right) \mathrm{S} / \mathrm{S}_{0}+\mathrm{c}_{2} \mathrm{~T}+\mathrm{e}_{3} \mathrm{P}+\mathrm{e}_{4} \mathrm{P}^{2}$ & $\mathrm{Ra}, \mathrm{S}, \mathrm{S}_{0}, \mathrm{~T}, \mathrm{P}$ & Chen et al [99] \\
\hline Group 8 & STP9 & $\begin{array}{l}\mathrm{Rs} / \mathrm{Ra}=\mathrm{a}+\left(\mathrm{a}_{1}+\mathrm{c}_{1} \mathrm{~T}+\mathrm{c}_{2} \mathrm{~T}^{2}+\mathrm{e}_{1} \mathrm{P}+\mathrm{e}_{2} \mathrm{P}^{2}\right) \mathrm{S} / \mathrm{S}_{0}+\mathrm{c}_{3} \mathrm{~T}+\mathrm{c}_{4} \mathrm{~T}^{2}+ \\
\mathrm{e}_{3} \mathrm{P}+\mathrm{e}_{4} \mathrm{P}^{2}\end{array}$ & $\mathrm{Ra}, \mathrm{S}, \mathrm{S}_{0}, \mathrm{~T}, \mathrm{P}$ & Chen et al [99] \\
\hline Group 8 & STP10 & $\begin{array}{l}\mathrm{Rs} / \mathrm{Ra}=\mathrm{a}+\left(\mathrm{a}_{1}+\mathrm{c}_{1} \mathrm{~T}+\mathrm{c}_{2} \mathrm{~T}^{2}+\mathrm{c}_{3} \mathrm{~T}^{3}+\mathrm{e}_{1} \mathrm{P}+\mathrm{e}_{2} \mathrm{P}^{2}\right) \mathrm{S} / \mathrm{S}_{0}+\mathrm{c}_{4} \mathrm{~T}+ \\
\mathrm{c}_{5} \mathrm{~T}^{2}+\mathrm{c}_{6} \mathrm{~T}^{3}+\mathrm{e}_{3} \mathrm{P}+\mathrm{e}_{4} \mathrm{P}^{2}\end{array}$ & $\mathrm{Ra}, \mathrm{S}, \mathrm{S}_{0}, \mathrm{~T}, \mathrm{P}$ & Chen et al [99] \\
\hline Group 9 & STPr1 & $\mathrm{Rs} / \mathrm{Ra}=\mathrm{a}+\left(\mathrm{a}_{1}+\mathrm{f}_{1} / \mathrm{Vp}\right) \mathrm{S} / \mathrm{S}_{0}+\mathrm{c}_{1} \ln \triangle \mathrm{T}$ & $\mathrm{Ra}, \mathrm{S}, \mathrm{S}_{0}, \mathrm{Tmax}, \mathrm{Tmin}, \mathrm{Vp}$ & Liu [44] \\
\hline Group 9 & STPr2 & $\mathrm{Rs} / \mathrm{Ra}=\mathrm{a}+\mathrm{b}_{1} \mathrm{~S} / \mathrm{S}_{0}+\mathrm{c}_{1} \operatorname{Tmin}+\mathrm{c}_{2} \operatorname{Tmax}+\mathrm{f}_{1} \mathrm{Ap}$ & $\mathrm{Ra}, \mathrm{S}, \mathrm{S}_{0}, \mathrm{Tmax}, \mathrm{Tmin}, \mathrm{Ap}$ & Chen and Li [20] \\
\hline Group 9 & STPr3 & $\begin{array}{l}R s=a+R a\left(a_{1}+b_{1} S / S_{0}+c_{1}(\triangle T)^{0.5}\right)+f_{1} D \\
D=0.6108 \exp (17.27 T /(T+273.3))-V p\end{array}$ & $\mathrm{Ra}, \mathrm{S}, \mathrm{S}_{0}, \mathrm{Tmax}, \mathrm{Tmin}, \mathrm{T}, \mathrm{Vp}$ & Chen et al [54] \\
\hline Group 10 & SRP1 & $R s=a+a_{1} R a+b_{1} S / S_{0}+d_{1} R h+e_{1} P$ & $\mathrm{Ra}, \mathrm{S}, \mathrm{S}_{0}, \mathrm{Rh}, \mathrm{P}$ & Saffaripour et al [42] \\
\hline Group 11 & STG1 & $\mathrm{Rs}=\mathrm{a}+\mathrm{b}_{1} \mathrm{~S} / \mathrm{S}_{0}+\mathrm{c}_{1} \mathrm{~T}+\mathrm{g}_{1} \sin \delta$ & $\mathrm{S}, \mathrm{S}_{0}, \mathrm{~T}, \delta$ & Togrul and Onat [95] \\
\hline Group 11 & STG2 & $\mathrm{Rs}=\mathrm{a}+\mathrm{b}_{1} \mathrm{~S} / \mathrm{S}_{0}+\mathrm{c}_{1} \mathrm{Tmax}+\mathrm{g}_{1} \sin \delta$ & $\mathrm{S}, \mathrm{S}_{0}, \mathrm{Tmax}, \delta$ & Chen et al [99] \\
\hline Group 12 & STRP1 & $R s / R a=a+b_{1} S / S_{0}+c_{1} T+d_{1} R h+e_{1} P$ & $\mathrm{Ra}, \mathrm{S}, \mathrm{S}_{0}, \mathrm{~T}, \mathrm{Rh}, \mathrm{P}$ & Kirmani et al [100] \\
\hline Group 12 & STRP2 & $\mathrm{Rs} / \mathrm{Ra}=\mathrm{a}+\mathrm{b}_{1} \mathrm{~S} / \mathrm{S}_{0}+\mathrm{c}_{1} \mathrm{Tmin} / \mathrm{Tmax}+\mathrm{d}_{1} \mathrm{Rh}+\mathrm{e}_{1} \mathrm{P}$ & $\mathrm{Ra}, \mathrm{S}, \mathrm{S}_{0}, \mathrm{Tmax}, \mathrm{Tmin}, \mathrm{Rh}, \mathrm{P}$ & Okonkwo and Nwokoye [46] \\
\hline
\end{tabular}




\begin{tabular}{|c|c|c|c|c|}
\hline Group 13 & STRPr1 & $\mathrm{Rs} / \mathrm{Ra}=\mathrm{a}+\mathrm{b}_{1} \mathrm{~S} / \mathrm{S}_{0}+\mathrm{c}_{1}(\triangle \mathrm{T})^{0.5}+\mathrm{d}_{1} \mathrm{Rh}+\mathrm{f}_{2} \mathrm{Ap}$ & $\begin{array}{l}\text { Ra, S, } S_{0}, \text { Tmax, Tmin, Rh, } \\
\text { Ap }\end{array}$ & Chen and $\mathrm{Li}[25]$ \\
\hline Group 13 & STRPr2 & $\mathrm{Rs} / \mathrm{Ra}=\mathrm{a}+\mathrm{b}_{1} \mathrm{~S} / \mathrm{S}_{0}+\mathrm{c}_{1} \mathrm{~T}+\mathrm{d}_{1} \mathrm{Rh}+\mathrm{f}_{1} \mathrm{Ap} / \mathrm{Aps}$ & $\mathrm{Ra}, \mathrm{S}, \mathrm{S}_{0}, \mathrm{~T}, \mathrm{Rh}, \mathrm{Ap}$ & Abdalla [120] \\
\hline Group 13 & STRPr3 & $\mathrm{Rs} / \mathrm{Ra}=\mathrm{a}+\mathrm{b}_{1} \mathrm{~S} / \mathrm{S}_{0}+\mathrm{c}_{1} \triangle \mathrm{T}+\mathrm{d}_{1} \mathrm{Rh}+\mathrm{f}_{1} \mathrm{Ap} / \mathrm{Aps}$ & $\mathrm{Ra}, \mathrm{S}, \mathrm{S}_{0}, \mathrm{~T}, \mathrm{Rh}, \mathrm{Ap}$ & Abdalla [120] \\
\hline Group 13 & STRPr4 & $\mathrm{Rs} / \mathrm{Ra}=\mathrm{a}+\mathrm{b}_{1} \mathrm{~S} / \mathrm{S}_{0}+\mathrm{c}_{1} \mathrm{Tmax}+\mathrm{d}_{1} \mathrm{Rh}+\mathrm{f}_{1} \mathrm{Ap} / \mathrm{Aps}+\mathrm{f}_{2} \mathrm{Vp}$ & $\mathrm{Ra}, \mathrm{S}, \mathrm{S}_{0}, \mathrm{~T}, \mathrm{Rh}, \mathrm{Ap}, \mathrm{Vp}$ & Trabea $[101]$ \\
\hline Group 14 & STPPr1 & $\mathrm{Rs}=\mathrm{a}+\mathrm{Ra}\left(\mathrm{a}_{1}+\mathrm{b}_{1} \mathrm{~S} / \mathrm{S}_{0}+\mathrm{c}_{1}(\triangle \mathrm{T})^{0.5}\right)+\mathrm{e}_{1} \mathrm{P}+\mathrm{c}_{2} \mathrm{D}$ & $\begin{array}{l}\mathrm{Ra}, \mathrm{S}, \mathrm{S}_{0}, \mathrm{Tmax}, \mathrm{Tmin}, \mathrm{T}, \mathrm{P}, \\
\mathrm{Vp}\end{array}$ & Chen et al [54] \\
\hline Group 15 & STRW1 & $\mathrm{Rs} / \mathrm{Ra}=\mathrm{a}+\mathrm{b}_{1} \mathrm{~S} / \mathrm{S}_{0}+\mathrm{c}_{1} \mathrm{~T}+\mathrm{d}_{1} \mathrm{Rh}+\mathrm{h}_{1} \mathrm{Wv}$ & $\mathrm{Ra}, \mathrm{S}, \mathrm{S}_{0}, \mathrm{~T}, \mathrm{Rh}, \mathrm{Wv}$ & Adeala et al [102] \\
\hline Group 16 & STRG1 & $\begin{array}{l}\mathrm{Rs}=\mathrm{a}_{1} \mathrm{~K}_{\varphi} \exp \left(\varphi\left(\mathrm{S} / \mathrm{S}_{0}-\mathrm{Rh} / 15-1 / \mathrm{Tmax}\right)\right. \\
\mathrm{K}_{\varphi}=4.18\left(\varphi 1^{*} \mathrm{~S}_{0}+\cos \varphi\right) * 10^{6}, \varphi 1=0.2 /(1+0.2 \varphi)\end{array}$ & $\mathrm{S}, \mathrm{S}_{0}, \mathrm{Tmax}, \mathrm{Rh}, \varphi$ & Sayigh [137] \\
\hline Group 16 & STRG2 & $\mathrm{Rs}=\mathrm{a}_{1} \mathrm{~K}_{\varphi} \exp \left(\varphi\left(\mathrm{S} / \mathrm{S}_{0}-\mathrm{Rh}^{1 / 3}-1 / \mathrm{Tmax}\right)\right)$ & $\mathrm{S}, \mathrm{S}_{0}, \mathrm{Tmax}, \mathrm{Rh}, \varphi$ & Sabbagh [138] \\
\hline Group 16 & STRG3 & $\begin{array}{l}\mathrm{Rs}=\mathrm{K}_{\varphi}\left(\mathrm{a}_{1}+\mathrm{b}_{1} \mathrm{~S} / \mathrm{S}_{0}+\mathrm{c}_{1} \mathrm{Tmin} / \mathrm{Tmax}+\mathrm{b}_{2} \mathrm{~S} / \mathrm{S}_{0}(\mathrm{Tmin} / \mathrm{Tmax})\right) \\
/(\mathrm{Rh})^{0.5}\end{array}$ & $\mathrm{~S}, \mathrm{~S}_{0}, \mathrm{Tmin}, \mathrm{Tmax}, \mathrm{Rh}, \varphi$ & Reddy [139] \\
\hline Group 16 & STRG4 & $\mathrm{Rs}=\mathrm{K}_{\varphi}\left(\mathrm{a}_{1}+\mathrm{b}_{1} \mathrm{~S} / \mathrm{S}_{0} * \mathrm{~T}+\mathrm{d}_{1} \mathrm{Rh}^{0.5}+\mathrm{d}_{2} \mathrm{Rh} / \mathrm{K}_{\varphi}+\mathrm{c}_{1} \mathrm{Rh}(\mathrm{T})^{0.5} / \mathrm{K}_{\varphi}\right)$ & $\mathrm{S}, \mathrm{S}_{0}, \mathrm{~T}, \mathrm{Rh}, \varphi$ & Reddy [139] \\
\hline Group 16 & STRG5 & $\mathrm{Rs}=\mathrm{a}+\mathrm{b}_{1} \mathrm{~S} / \mathrm{S}_{0}+\mathrm{c}_{1} \mathrm{~T}+\mathrm{d}_{1} \mathrm{Rh}+\mathrm{g}_{1} \sin \delta$ & $\mathrm{S}, \mathrm{S}_{0}, \mathrm{~T}, \mathrm{Rh}, \delta$ & Togrul and Onat [95] \\
\hline Group 16 & STRG6 & $R s=a+a_{1} R_{a}+b_{1} S / S_{0}+c_{1} T+d_{1} R h+g_{1} \sin \delta$ & $\mathrm{Ra}, \mathrm{S}, \mathrm{S}_{0}, \mathrm{~T}, \mathrm{Rh}, \delta$ & Togrul and Onat [95] \\
\hline Group 16 & STRG7 & $R s=a+a_{1} R a+b_{1} S / S_{0}+c_{1} T \max +d_{1} R h+g_{1} \sin \delta$ & $\mathrm{Ra}, \mathrm{S}, \mathrm{S}_{0}, \mathrm{Tmax}, \mathrm{Rh}, \delta$ & Chen et al [99] \\
\hline Group 16 & STRG8 & $\mathrm{Rs} / \mathrm{Ra}=\mathrm{a}+\mathrm{b}_{1} \mathrm{~S} / \mathrm{S}_{0}+\mathrm{c}_{1} \mathrm{~T}+\mathrm{d}_{1} \mathrm{Rh}+\mathrm{g}_{1} \cos \varphi+\mathrm{g}_{2} \mathrm{Z}$ & $\mathrm{Ra}, \mathrm{S}, \mathrm{S}_{0}, \mathrm{~T}, \mathrm{Rh}, \varphi, \mathrm{Z}$ & Gopinathan [130] \\
\hline Group 16 & STRG9 & $R s=a+a_{1} R a+b_{1} S / S_{0}+c_{1} T+c_{2} T \min / T \max +d_{1} R h+g_{1} \delta$ & $\begin{array}{l}\mathrm{Ra}, \mathrm{S}, \mathrm{S}_{0}, \mathrm{~T}, \mathrm{Tmax}, \mathrm{Tmin} \mathrm{Rh}, \\
\delta\end{array}$ & Akpabio et al [61] \\
\hline Group 16 & STRG10 & $\begin{array}{l}\mathrm{Rs} / \mathrm{Ra}=\mathrm{a}+\mathrm{b}_{1} \mathrm{~S} / \mathrm{S}_{0}+\mathrm{c}_{1} \mathrm{Tmax}+\mathrm{c}_{2} \mathrm{Tmax} / \mathrm{Rh}+\mathrm{c}_{3}(\mathrm{Tmax} / \mathrm{Rh})^{2}+ \\
\mathrm{g}_{1} \cos \varphi+\mathrm{g}_{2} \cos n+\mathrm{g}_{3}(\cos \varphi)(\cos n)\end{array}$ & $\mathrm{Ra}, \mathrm{S}, \mathrm{S}_{0}, \mathrm{Tmax}, \mathrm{Rh}, \varphi, \mathrm{n}$ & Ajayi et al [103] \\
\hline Group 16 & STRG11 & $\begin{array}{l}\mathrm{Rs} / \mathrm{Ra}=\mathrm{a}+\mathrm{b}_{1} \mathrm{~S} / \mathrm{S}_{0}+\mathrm{c}_{1} \mathrm{Tmax}+\mathrm{c}_{2} \mathrm{Tmax} / \mathrm{Rh}+\mathrm{c}_{3}(\mathrm{Tmax} / \mathrm{Rh})^{2}+ \\
\mathrm{c}_{4} \operatorname{Tmax} / \cos \varphi+\mathrm{g}_{1} \cos \varphi+\mathrm{g}_{2} \cos n+\mathrm{g}_{3}(\cos \varphi)(\cos n)\end{array}$ & $\mathrm{Ra}, \mathrm{S}, \mathrm{S}_{0}, \mathrm{Tmax}, \mathrm{Rh}, \varphi, \mathrm{n}$ & Ajayi et al [103] \\
\hline Group 16 & STRG12 & $\begin{array}{l}\mathrm{Rs} / \mathrm{Ra}=\mathrm{a}+\mathrm{b}_{1} \mathrm{~S} / \mathrm{S}+\mathrm{c}_{1} \mathrm{Tmax}+\mathrm{d}_{1} \mathrm{Rh}+\mathrm{c}_{2} \mathrm{Tmax} / \mathrm{Rh}+ \\
\mathrm{c}_{3}(\mathrm{Tmax} / \mathrm{Rh})^{2}+\mathrm{g}_{1} \cos \varphi+\mathrm{g}_{2} \cos n+\mathrm{g}_{3}(\cos \varphi)(\cos n)+\mathrm{g}_{4}(\cos n)^{2}\end{array}$ & $\mathrm{Ra}, \mathrm{S}, \mathrm{S}_{0}, \mathrm{Tmax}, \mathrm{Rh}, \varphi, \mathrm{n}$ & Ajayi et al [103] \\
\hline Group 16 & STRG13 & $\mathrm{Rs} / \mathrm{Ra}=\mathrm{a}+\mathrm{b}_{1} \mathrm{~S} / \mathrm{S}+\mathrm{b}_{2}\left(\mathrm{~S} / \mathrm{S}_{0}\right)^{2}+\mathrm{c}_{1} \mathrm{Tmax}+\mathrm{c}_{2} \operatorname{Tmax} / \mathrm{Rh}+$ & $\mathrm{Ra}, \mathrm{S}, \mathrm{S}_{0}, \mathrm{Tmax}, \mathrm{Rh}, \varphi, \mathrm{n}$ & Ajayi et al [103] \\
\hline
\end{tabular}




\begin{tabular}{|c|c|c|c|c|}
\hline & & $\begin{array}{l}c_{3}(\operatorname{Tmax} / R h)^{2}+c_{4}(\operatorname{Tmax} / R h)^{3}+c_{5} \operatorname{Tmax} / \cos \varphi+g_{1} \cos \varphi+ \\
g_{2} \cos n+g_{3}(\cos \varphi)(\cos n)+g_{4}(\cos n)^{2}\end{array}$ & & \\
\hline Group 17 & STPG1 & $\mathrm{Rs} / \mathrm{Ra}=\mathrm{a}+\mathrm{b}_{1} \mathrm{~S} / \mathrm{S}_{0}+\mathrm{c}_{1} \mathrm{~T}+\mathrm{e}_{1} \mathrm{P}+\mathrm{g}_{1} \varphi+\mathrm{g}_{2} \mathrm{Z}+\mathrm{g}_{3} \lambda$ & $\mathrm{Ra}, \mathrm{S}, \mathrm{S}_{0}, \mathrm{~T}, \mathrm{P}, \varphi, \mathrm{Z}, \lambda$ & Chen et al [99] \\
\hline Group 17 & STPG2 & $\mathrm{Rs} / \mathrm{Ra}=\mathrm{a}+\mathrm{b}_{1} \mathrm{~S} / \mathrm{S}_{0}+\mathrm{c}_{1} \mathrm{~T}+\mathrm{e}_{1} \mathrm{P}+\mathrm{e}_{2} \mathrm{P}^{2}+\mathrm{g}_{1} \varphi+\mathrm{g}_{2} \mathrm{Z}+\mathrm{g}_{3} \lambda$ & $\mathrm{Ra}, \mathrm{S}, \mathrm{S}_{0}, \mathrm{~T}, \mathrm{P}, \varphi, \mathrm{Z}, \lambda$ & Chen et al [99] \\
\hline Group 17 & STPG3 & $\begin{array}{l}\mathrm{Rs} / \mathrm{Ra}=\mathrm{a}+\mathrm{b}_{1} \mathrm{~S} / \mathrm{S}_{0}+\mathrm{c}_{1} \mathrm{~T}+\mathrm{c}_{2} \mathrm{~T}^{2}+\mathrm{c}_{3} \mathrm{~T}^{3}+\mathrm{e}_{1} \mathrm{P}+\mathrm{g}_{1} \varphi+\mathrm{g}_{2} \mathrm{Z}+ \\
\mathrm{g}_{3} \lambda\end{array}$ & $\mathrm{Ra}, \mathrm{S}, \mathrm{S}_{0}, \mathrm{~T}, \mathrm{P}, \varphi, \mathrm{Z}, \lambda$ & Chen et al [99] \\
\hline Group 17 & STPG4 & $\begin{array}{l}\mathrm{Rs} / \mathrm{Ra}=\mathrm{a}+\mathrm{b}_{1} \mathrm{~S} / \mathrm{S}_{0}+\mathrm{c}_{1} \mathrm{~T}+\mathrm{c}_{2} \mathrm{~T}^{2}+\mathrm{c}_{3} \mathrm{~T}^{3}+\mathrm{e}_{1} \mathrm{P}+\mathrm{e}_{2} \mathrm{P}^{2}+\mathrm{g}_{1} \varphi+ \\
\mathrm{g}_{2} \mathrm{Z}+\mathrm{g}_{3} \lambda\end{array}$ & $\mathrm{Ra}, \mathrm{S}, \mathrm{S}_{0}, \mathrm{~T}, \mathrm{P}, \varphi, \mathrm{Z}, \lambda$ & Chen et al [99] \\
\hline Group 17 & STPG5 & $\begin{array}{l}\mathrm{Rs} / \mathrm{Ra}=\mathrm{a}+\left(\mathrm{a}_{1}+\mathrm{g}_{1} \varphi+\mathrm{g}_{2} \mathrm{Z}+\mathrm{g}_{3} \lambda\right) \mathrm{S} / \mathrm{S}_{0}+\mathrm{c}_{1} \mathrm{~T}+\mathrm{e}_{1} \mathrm{P}+\mathrm{g}_{4} \varphi+ \\
\mathrm{g}_{5} \mathrm{Z}+\mathrm{g}_{6} \lambda\end{array}$ & $\mathrm{Ra}, \mathrm{S}, \mathrm{S}_{0}, \mathrm{~T}, \mathrm{P}, \varphi, \mathrm{Z}, \lambda$ & Chen et al [99] \\
\hline Group 18 & STRPP1 & $R s=a+R a\left(a_{1}+b_{1} S / S_{0}\right)+c_{1}(\triangle T)^{0.5}+c_{2} T+d_{1} R h+e_{1} P+c_{3} D$ & $\begin{array}{l}\mathrm{Ra}, \mathrm{S}, \mathrm{S}_{0}, \mathrm{Tmax}, \mathrm{Tmin}, \mathrm{T} \\
\mathrm{Rh}, \mathrm{P}, \mathrm{Vp}\end{array}$ & Chen et al [99] \\
\hline Group 18 & STRPP2 & $\begin{array}{l}\mathrm{Rs} / \mathrm{Ra}=\mathrm{a}+\mathrm{b}_{1}\left(\mathrm{~S} / \mathrm{S}_{0}\right)^{\mathrm{b} 2}+\mathrm{c}_{1} \ln \triangle \mathrm{T}+\mathrm{c}_{2} \mathrm{~T}+\mathrm{d}_{1} \mathrm{Rh}+\mathrm{e}_{1} \ln (\mathrm{P}+1) \\
+\mathrm{c}_{3} \mathrm{D}\end{array}$ & $\begin{array}{l}\text { Ra, S, S }, \text { Tmax, Tmin, T, } \\
\text { Rh, P, Vp }\end{array}$ & Fan et al [45] \\
\hline Group 19 & STRPW1 & $\mathrm{Rs} / \mathrm{Ra}=\mathrm{a}+\mathrm{b}_{1} \mathrm{~S} / \mathrm{S}_{0}+\mathrm{c}_{1} \mathrm{~T}+\mathrm{d}_{1} \mathrm{Rh}+\mathrm{e}_{1} \mathrm{P}+\mathrm{h}_{1} \mathrm{Wv}$ & $\mathrm{Ra}, \mathrm{S}, \mathrm{S} 0, \mathrm{~T}, \mathrm{Rh}, \mathrm{P}, \mathrm{Wv}$ & Ouali and Alkama [104] \\
\hline Group 19 & STRPW2 & $\begin{array}{l}\mathrm{Rs} / \mathrm{Ra}=\mathrm{a}+\mathrm{b}_{1} \mathrm{~S} / \mathrm{S}_{0}+\mathrm{c}_{1} \mathrm{~T}+\mathrm{d}_{1} \mathrm{Rh}+\mathrm{e}_{1} \mathrm{P}+\mathrm{h}_{1} \mathrm{Wv}+\mathrm{b}_{2}\left(\mathrm{~S} / \mathrm{S}_{0} * \mathrm{P} *\right. \\
\mathrm{Wv} * \mathrm{Rh} * \mathrm{~T})\end{array}$ & $\mathrm{Ra}, \mathrm{S}, \mathrm{S} 0, \mathrm{~T}, \mathrm{Rh}, \mathrm{P}, \mathrm{Wv}$ & Ouali and Alkama [104] \\
\hline Group 20 & STRPG1 & $\begin{array}{l}\mathrm{Rs}=\mathrm{a}+\mathrm{a}_{1} \mathrm{Ra}+\mathrm{b}_{1} \mathrm{~S} / \mathrm{S}_{0}+\mathrm{c}_{1} \mathrm{~T}+\mathrm{c}_{2} \mathrm{Tmin} / \mathrm{Tmax}+\mathrm{d}_{1} \mathrm{Rh}+\mathrm{e}_{1} \mathrm{P}+ \\
\mathrm{g}_{1} \delta\end{array}$ & $\begin{array}{l}\mathrm{Ra}, \mathrm{S}, \mathrm{S}_{0}, \mathrm{~T}, \mathrm{Tmax}, \mathrm{Tmin} \\
\mathrm{Rh}, \mathrm{P}, \delta\end{array}$ & Akpabio et al [61] \\
\hline Group 20 & STRPG2 & $\begin{array}{l}\mathrm{Rs} / \mathrm{Ra}=\left(\mathrm{a}_{1}+\mathrm{g}_{1} \sin \mathrm{M}+\mathrm{g}_{2} \cos \mathrm{M}+\mathrm{b}_{1} \mathrm{~S}+\mathrm{d}_{1} \mathrm{Rh}+\mathrm{e}_{1} \mathrm{P}\right)(1-\exp \\
\left.\left(\mathrm{c}_{2}(\triangle \mathrm{T})^{\mathrm{c} 3}\right)\right), \mathrm{M}=2 \pi \mathrm{n} / 365\end{array}$ & $\mathrm{Ra}, \mathrm{S}, \mathrm{Tmax}, \mathrm{Tmin}, \mathrm{Rh}, \mathrm{P}, \mathrm{n}$ & Zou et al [105] \\
\hline Group 21 & $\mathrm{~T} 1$ & $\mathrm{Rs} / \mathrm{Ra}=\mathrm{c}_{1}(\triangle \mathrm{T})^{0.5}$ & Ra, Tmax, Tmin & Hargreaves and Samani [49] \\
\hline Group 21 & $\mathrm{~T} 2$ & $\mathrm{Rs} / \mathrm{Ra}=\mathrm{c}_{1}(\triangle \mathrm{T})^{\mathrm{c} 2}$ & Ra, Tmax, Tmin & Richardson [140] \\
\hline Group 21 & $\mathrm{~T} 3$ & $\mathrm{Rs} / \mathrm{Ra}=\mathrm{c}_{1} \exp \left(\mathrm{c}_{2} \mathrm{~T}^{\mathrm{c} 3}\right)$ & $\mathrm{Ra}, \mathrm{T}$ & Hassan et al [51] \\
\hline Group 21 & $\mathrm{~T} 4$ & $\mathrm{Rs} / \mathrm{Ra}=\mathrm{a}+\mathrm{c}_{1} \triangle \mathrm{T}$ & Ra, Tmax, Tmin & Chen and Li [20] \\
\hline Group 21 & T5 & $\mathrm{Rs} / \mathrm{Ra}=\mathrm{a}+\mathrm{c}_{1}(\triangle \mathrm{T})^{0.5}$ & Ra, Tmax, Tmin & Hargreaves et al [141] \\
\hline Group 21 & T6 & $\mathrm{Rs} / \mathrm{Ra}=\mathrm{a}+\mathrm{c}_{1}(\triangle \mathrm{T})^{\mathrm{c} 2}$ & Ra, Tmax, Tmin & Hassan et al [51] \\
\hline
\end{tabular}




\begin{tabular}{|c|c|c|c|c|}
\hline Group 21 & $\mathrm{~T} 7$ & $\mathrm{Rs} / \mathrm{Ra}=\mathrm{a}+\mathrm{c}_{1} \ln (\triangle \mathrm{T})$ & Ra, Tmax, Tmin & Chen et al 2004 [121] \\
\hline Group 21 & $\mathrm{~T} 8$ & $\mathrm{Rs} / \mathrm{Ra}=\left(\mathrm{a}_{1}+\mathrm{c}_{1} \triangle \mathrm{T}\right)(\triangle \mathrm{T})^{\mathrm{c} 2}$ & Ra, Tmax, Tmin & Hassan et al [51] \\
\hline Group 21 & T9 & $\mathrm{Rs} / \mathrm{Ra}=\left(\mathrm{a}_{1}+\mathrm{c}_{1} \mathrm{~T}\right)(\triangle \mathrm{T})^{\mathrm{c} 2}$ & Ra, Tmax, Tmin & Hassan et al [51] \\
\hline Group 21 & $\mathrm{~T} 10$ & $\mathrm{Rs}=\mathrm{a}+\mathrm{c}_{1} \operatorname{Ra}(\triangle \mathrm{T})^{0.5}$ & Ra, Tmax, Tmin & Hunt et al 139 [145] \\
\hline Group 21 & $\mathrm{~T} 11$ & $\mathrm{Rs}=\mathrm{a}+\mathrm{c}_{1} \operatorname{Ra}(\triangle \mathrm{T})^{0.25}$ & Ra, Tmax, Tmin & Benghanem and Mellit [50] \\
\hline Group 21 & $\mathrm{~T} 12$ & $\mathrm{Rs} / \mathrm{Ra}=\mathrm{a}+\mathrm{c}_{1} \operatorname{Ra}(\mathrm{T})^{\mathrm{c} 2}$ & Ra, Tmax, Tmin & Hassan et al [51] \\
\hline Group 21 & $\mathrm{~T} 13$ & $\mathrm{Rs} / \mathrm{Ra}=\mathrm{a}+\mathrm{c}_{1} \mathrm{~T}$ & $\mathrm{Ra}, \mathrm{T}$ & Falayi et al [85] \\
\hline Group 21 & $\mathrm{~T} 14$ & $\mathrm{Rs} / \mathrm{Ra}=\mathrm{a}+\mathrm{c}_{1} \mathrm{Tmax}$ & Ra, Tmax, & Awachie and Okeke [143] \\
\hline Group 21 & $\mathrm{~T} 15$ & $\mathrm{Rs} / \mathrm{Ra}=\mathrm{a}+\mathrm{c}_{1}(\mathrm{Tmax} / 65)$ & Ra, Tmax, & Mubiru et al [111] \\
\hline Group 21 & $\mathrm{~T} 16$ & $\mathrm{Rs} / \mathrm{Ra}=\mathrm{a}+\mathrm{c}_{1} \mathrm{Tmin}$ & $\mathrm{Ra}$, Tmin & Falayi et al [85] \\
\hline Group 21 & $\mathrm{~T} 17$ & $\mathrm{Rs} / \mathrm{Ra}=\mathrm{a}+\mathrm{c}_{1} \mathrm{Tmin} * \mathrm{Tmax}$ & Ra, Tmax, Tmin & Pandey and Katiyar [144] \\
\hline Group 21 & $\mathrm{~T} 18$ & $\mathrm{Rs} / \mathrm{Ra}=1-\exp \left(\mathrm{c}_{1}(\triangle \mathrm{T})^{\mathrm{c} 2}\right)$ & Ra, Tmax, Tmin & Thornton and Running [96] \\
\hline Group 21 & $\mathrm{~T} 19$ & $\mathrm{Rs} / \mathrm{Ra}=\mathrm{c}_{1}\left(1-\exp \left(\mathrm{c}_{2}(\triangle \mathrm{T})^{\mathrm{c} 3}\right)\right)$ & Ra, Tmax, Tmin & Bristow and Campbell [55] \\
\hline Group 21 & $\mathrm{~T} 20$ & $\mathrm{Rs} / \mathrm{Ra}=0.75\left(1-\exp \left(\mathrm{c}_{1}(\triangle \mathrm{T})^{2}\right)\right)$ & Ra, Tmax, Tmin & Meza [145] \\
\hline Group 21 & $\mathrm{~T} 21$ & $\mathrm{Rs} / \mathrm{Ra}=\mathrm{c}_{1}\left(1-\exp \left(\mathrm{c}_{2}(\Delta \mathrm{T})^{\mathrm{c} 3} / \mathrm{Ra}\right)\right)$ & Ra, Tmax, Tmin & Goodin et al. [57] \\
\hline Group 21 & $\mathrm{~T} 22$ & $\mathrm{Rs} / \mathrm{Ra}=\mathrm{c}_{1}\left(1-\exp \left(\mathrm{c}_{2}(\triangle \mathrm{T})^{\mathrm{c} 3} / \mathrm{T}\right)\right)$ & Ra, T, Tmax, Tmin & Donatelli and Campbell [146] \\
\hline Group 21 & $\mathrm{~T} 23$ & $\mathrm{Rs} / \mathrm{Ra}=0.75\left(1-\exp \left(\mathrm{c}_{1}(\triangle \mathrm{T})^{2} / \mathrm{T}\right)\right)$ & $\mathrm{Ra}, \mathrm{T}, \mathrm{Tmax}, \mathrm{Tmin}$ & Abraha and Savage [147] \\
\hline Group 21 & $\mathrm{~T} 24$ & $\begin{array}{l}\mathrm{Rs} / \mathrm{Ra}=\mathrm{c}_{1}\left(1-\exp \left(\mathrm{c}_{2}(\triangle T)^{\mathrm{c} 3} \mathrm{f}(\mathrm{T})\right)\right. \\
\mathrm{f}(\mathrm{T})=0.017 \exp (\exp (-0.053 \mathrm{~T}))\end{array}$ & $\mathrm{Ra}, \mathrm{T}, \mathrm{Tmax}, \mathrm{Tmin}$ & Donatelli and Campbell [146] \\
\hline Group 21 & $\mathrm{~T} 25$ & $\mathrm{Rs} / \mathrm{Ra}=0.75\left(1-\exp \left(\mathrm{c}_{1}(\triangle \mathrm{T})^{2} \mathrm{f}(\mathrm{T})\right)\right.$ & $\mathrm{Ra}, \mathrm{T}, \mathrm{Tmax}, \mathrm{Tmin}$ & Weiss et al [87] \\
\hline Group 21 & $\mathrm{~T} 26$ & $\begin{array}{l}\mathrm{Rs} / \mathrm{Ra}=\mathrm{c}_{1}\left(1-\exp \left(\mathrm{c}_{2}(\triangle \mathrm{T})^{\mathrm{c} 3} \mathrm{f}(\mathrm{T}) \mathrm{f}(\mathrm{Tmin})\right)\right. \\
\mathrm{f}(\mathrm{Tmin})=\exp (\mathrm{Tmin} / 24.2807)\end{array}$ & $\mathrm{Ra}, \mathrm{T}, \mathrm{Tmax}, \mathrm{Tmin}$ & Weiss et al [87] \\
\hline Group 21 & $\mathrm{~T} 27$ & $\mathrm{Rs} / \mathrm{Ra}=0.75\left(1-\exp \left(\mathrm{c}_{1}(\triangle \mathrm{T})^{2} \mathrm{f}(\mathrm{T}) \mathrm{f}(\mathrm{Tmin})\right)\right.$ & Ra, T, Tmax, Tmin & Abraha and Savage [147] \\
\hline Group 21 & $\mathrm{~T} 28$ & $\mathrm{Rs} / \mathrm{Ra}=\mathrm{c}_{1}\left(1-\exp \left(\mathrm{c}_{2}(\triangle \mathrm{T})^{0.5}-\mathrm{c}_{3} \triangle \mathrm{T}-\mathrm{c}_{4}(\triangle \mathrm{T})^{2}\right)\right.$ & Ra, Tmax, Tmin & Hunt et al [142] \\
\hline Group 21 & $\mathrm{~T} 29$ & $\mathrm{Rs} / \mathrm{Ra}=\mathrm{c}_{1}\left(1-\mathrm{c}_{2} \operatorname{Es}(\operatorname{Tmin}) / \mathrm{Es}(\operatorname{Tmax})\right)$ & Ra, Tmax, Tmin & Winslow et al [148] \\
\hline
\end{tabular}


$\operatorname{Es}(\mathrm{T})=0.6108 \exp (17.27 \mathrm{~T} /(\mathrm{T}+273.3))$

\begin{tabular}{|c|c|c|}
\hline Group 21 & $\mathrm{~T} 30$ & $\mathrm{Rs} / \mathrm{Ra}=\mathrm{c}_{1}(\triangle \mathrm{T})^{\mathrm{c} 2}\left(1-\exp \left(\mathrm{c}_{3}(\operatorname{Es}(\mathrm{Tmin}))^{\mathrm{c} 4}\right)\right.$ \\
\hline Group 21 & $\mathrm{~T} 31$ & $\mathrm{Rs} / \mathrm{Ra}=\mathrm{c}_{1}(\triangle \mathrm{T})^{\mathrm{c} 2}\left(1-\exp \left(\mathrm{c}_{3}(\operatorname{Es}(\operatorname{Tmin}) / \operatorname{Es}(\operatorname{Tmax}))^{\mathrm{c4}}\right)\right.$ \\
\hline Group 21 & $\mathrm{~T} 32$ & $\mathrm{Rs}=\mathrm{a}+\mathrm{a}_{1} \mathrm{Ra}+\mathrm{c}_{1} \mathrm{~T}$ \\
\hline Group 21 & $\mathrm{~T} 33$ & $\mathrm{Rs} / \mathrm{Ra}=\mathrm{a}+\left(\mathrm{a}_{1}+\mathrm{c}_{1} \mathrm{~T}\right)(\triangle \mathrm{T})^{0.5}$ \\
\hline Group 21 & $\mathrm{~T} 34$ & $\mathrm{Rs} / \mathrm{Ra}=\mathrm{a}+\left(\mathrm{a}_{1}+\mathrm{c}_{1} \mathrm{~T}\right)(\triangle \mathrm{T})^{\mathrm{c} 2}$ \\
\hline Group 21 & $\mathrm{~T} 35$ & $\mathrm{Rs} / \mathrm{Ra}=\mathrm{a}+\mathrm{c}_{1}(\triangle \mathrm{T})^{0.5}+\mathrm{c}_{2}(\triangle \mathrm{T})$ \\
\hline Group 21 & $\mathrm{~T} 36$ & $\mathrm{Rs} / \mathrm{Ra}=\mathrm{a}+\mathrm{c}_{1} \mathrm{~T}+\mathrm{c}_{2} \mathrm{~T}^{2}$ \\
\hline Group 21 & $\mathrm{~T} 37$ & $\mathrm{Rs} / \mathrm{Ra}=\left(\mathrm{a}_{1}+\mathrm{c}_{1} \triangle \mathrm{T}+\mathrm{c}_{2}(\triangle \mathrm{T})^{2}\right)(\triangle \mathrm{T})^{\mathrm{c} 3}$ \\
\hline Group 21 & $\mathrm{~T} 38$ & $\mathrm{Rs} / \mathrm{Ra}=\left(\mathrm{a}_{1}+\mathrm{c}_{1} \mathrm{~T}+\mathrm{c}_{2} \mathrm{~T}^{2}\right)(\triangle \mathrm{T})^{\mathrm{c} 3}$ \\
\hline Group 21 & $\mathrm{~T} 39$ & $\mathrm{Rs} / \mathrm{Ra}=\left(\mathrm{a}_{1}+\mathrm{c}_{1} \triangle \mathrm{T}+\mathrm{c}_{2}(\triangle \mathrm{T})^{2}\right)(\triangle \mathrm{T})^{0.5}$ \\
\hline Group 21 & $\mathrm{~T} 40$ & $\mathrm{Rs}=\mathrm{a}+\left(\mathrm{c}_{1} \mathrm{Tmax}+\mathrm{c}_{2} \mathrm{Tmin}\right) \mathrm{Ra}$ \\
\hline Group 21 & $\mathrm{~T} 41$ & $\mathrm{Rs} / \mathrm{Ra}=\mathrm{a}+\mathrm{c}_{1} \mathrm{Tmax}+\mathrm{c}_{2} \mathrm{Tmin}$ \\
\hline Group 21 & $\mathrm{~T} 42$ & $\mathrm{Rs} / \mathrm{Ra}=\mathrm{a}+\mathrm{c}_{1} \mathrm{Tmin} / \mathrm{Tmax}+\mathrm{c}_{2} \mathrm{~T} \max$ \\
\hline Group 21 & $\mathrm{~T} 43$ & $\mathrm{Rs} / \mathrm{Ra}=\mathrm{a}+\mathrm{c}_{1} \operatorname{Tmin}+\mathrm{c}_{2} \operatorname{Tmin}^{2}$ \\
\hline Group 21 & $\mathrm{~T} 44$ & $\mathrm{Rs} / \mathrm{Ra}=\mathrm{a}+\mathrm{c}_{1} \mathrm{Tmax}+\mathrm{c}_{2} \operatorname{Tmax}^{2}$ \\
\hline Group 21 & $\mathrm{~T} 45$ & $\mathrm{Rs} / \mathrm{Ra}=\left(\mathrm{a}_{1}+\mathrm{c}_{1} \operatorname{Tmin} / \mathrm{Tmax}\right)(\operatorname{Tmin} / \mathrm{Tmax})^{\mathrm{c} 2}$ \\
\hline Group 21 & $\mathrm{~T} 46$ & $\mathrm{Rs} / \mathrm{Ra}=\mathrm{a}+\mathrm{c}_{1} \mathrm{Tmin} / \mathrm{Tmax}+\mathrm{c}_{2}(\mathrm{~T} \min / \mathrm{Tmax})^{2}$ \\
\hline Group 21 & $\mathrm{~T} 47$ & $\mathrm{Rs} / \mathrm{Ra}=\mathrm{a}+\mathrm{c}_{1} \operatorname{Tmin} * \mathrm{Tmax}+\mathrm{c}_{2}(\operatorname{Tmin} * \mathrm{Tmax})^{2}$ \\
\hline Group 21 & $\mathrm{~T} 48$ & $\mathrm{Rs} / \mathrm{Ra}=\mathrm{a}+\mathrm{c}_{1} \mathrm{~T}+\mathrm{c}_{2} \mathrm{~T}^{2}+\mathrm{c}_{2} \mathrm{~T}^{3}$ \\
\hline Group 21 & $\mathrm{~T} 49$ & $\mathrm{Rs} / \mathrm{Ra}=\mathrm{a}+\mathrm{c}_{1}(\triangle \mathrm{T})^{0.25}+\mathrm{c}_{2}(\triangle \mathrm{T})^{0.5}+\mathrm{c}_{3} \triangle \mathrm{T}$ \\
\hline Group 21 & $\mathrm{~T} 50$ & $\mathrm{Rs} / \mathrm{Ra}=\mathrm{a}+\mathrm{c}_{1}(\triangle \mathrm{T})^{0.5}+\mathrm{c}_{2}(\triangle \mathrm{T})^{1.5}+\mathrm{c}_{3}(\triangle \mathrm{T})^{2.5}$ \\
\hline Group 21 & T51 & $\mathrm{Rs} / \mathrm{Ra}=\mathrm{a}+\mathrm{c}_{1} \triangle \mathrm{T}+\mathrm{c}_{2}(\triangle \mathrm{T})^{2}+\mathrm{c}_{3}(\triangle \mathrm{T})^{3}$ \\
\hline Group 21 & $\mathrm{~T} 52$ & $\mathrm{Rs} / \mathrm{Ra}=\mathrm{a}+\left(\mathrm{a}_{1}+\mathrm{c}_{1} \mathrm{~T}+\mathrm{c}_{2} \mathrm{~T}^{2}\right)(\triangle \mathrm{T})^{\mathrm{c} 3}$ \\
\hline
\end{tabular}

Ra, Tmax, Tmin

Ra, Tmax, Tmin

$\mathrm{Ra}, \mathrm{T}$

Ra, T, Tmax, Tmin

Ra, T, Tmax, Tmin

Ra, T, Tmax, Tmin

Ra, T

Ra, Tmax, Tmin

Ra, T, Tmax, Tmin

Ra, T, Tmax, Tmin

Ra, Tmax, Tmin

Ra, Tmax, Tmin

Ra, Tmax, Tmin

Ra, Tmin

Ra, Tmax

Ra, Tmax, Tmin

Ra, Tmax, Tmin

Ra, Tmax, Tmin

Ra, T

Ra, Tmax, Tmin

Ra, Tmax, Tmin

Ra, Tmax, Tmin

Ra, T, Tmax, Tmin
Almorox et al [149]

Almorox et al [149]

Ertekin and Yaldiz [150]

Li et al [151]

Hassan et al [51]

Ohunakin et al [152]

Ohunakin et al [152]

Hassan et al [51]

Hassan et al [51]

Samani [153]

Li et al [154]

$\mathrm{Li}$ et al [107]

Okundamiya and Nzeako [155]

Okundamiya and Nzeako [155]

Okundamiya and Nzeako [155]

Richardson and Reddy [109]

Pandey and Katiyar [144]

Okonkwo and Nwokoye [46]

Hassan et al [50]

Fan et al [56]

Jahani et al [157]

Jahani et al [156]

Hassan et al [51] 


\begin{tabular}{|c|c|c|c|c|}
\hline Group 21 & $\mathrm{~T} 53$ & $\mathrm{Rs} / \mathrm{Ra}=\mathrm{a}+\left(\mathrm{a}_{1}+\mathrm{c}_{1} \triangle \mathrm{T}+\mathrm{c}_{2}(\triangle \mathrm{T})^{2}\right)(\triangle \mathrm{T})^{\mathrm{c} 3}$ & Ra, Tmax, Tmin & Hassan et al [51] \\
\hline Group 21 & $\mathrm{~T} 54$ & $\mathrm{Rs} / \mathrm{Ra}=\left(\mathrm{a}_{1}+\mathrm{c}_{1} \mathrm{~T}+\mathrm{c}_{2} \mathrm{~T}^{2}+\mathrm{c}_{3} \mathrm{~T}^{3}\right)(\triangle \mathrm{T})^{\mathrm{c} 4}$ & Ra, T, Tmax, Tmin & Hassan et al [51] \\
\hline Group 21 & T55 & $\mathrm{Rs}=\mathrm{a}+\mathrm{a}_{1} \mathrm{Ra}+\mathrm{c}_{1} \mathrm{Tmax}+\mathrm{c}_{2} \mathrm{Tmin}$ & Ra, Tmax, Tmin & Almorox et al [157] \\
\hline Group 21 & T56 & $\mathrm{Rs} / \mathrm{Ra}=\mathrm{a}+\mathrm{c}_{1} \mathrm{Tmax}+\mathrm{c}_{2} \mathrm{Tmin}+\mathrm{c}_{3} \mathrm{Tmin} * \mathrm{Tmax}$ & Ra, Tmax, Tmin & Chen and $\mathrm{Li}[20]$ \\
\hline Group 21 & T57 & 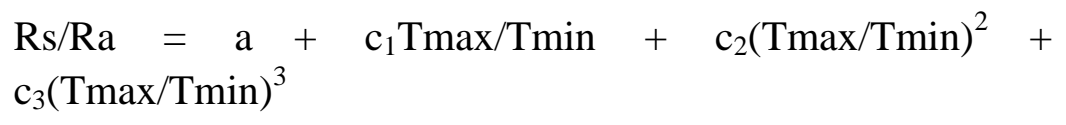 & Ra, Tmax, Tmin & Pandey and Katiyar [144] \\
\hline Group 21 & T58 & $\operatorname{Rs}=\operatorname{Ra}\left(a_{1}+c_{1}(\triangle T)^{0.25}+c_{2}(\triangle T)^{0.5}+c_{3} \triangle T\right)+c_{4} T$ & $\mathrm{Ra}, \mathrm{T}, \mathrm{Tmax}, \mathrm{Tmin}$ & Fan et al [56] \\
\hline Group 21 & T59 & $\mathrm{Rs} / \mathrm{Ra}=\mathrm{a}+\left(\mathrm{a}_{1}+\mathrm{c}_{1} \triangle \mathrm{T}+\mathrm{c}_{2}(\triangle \mathrm{T})^{2}+\mathrm{c}_{3}(\triangle \mathrm{T})^{3}\right)(\triangle \mathrm{T})^{\mathrm{c} 4}$ & Ra, Tmax, Tmin & Hassan et al [51] \\
\hline Group 21 & T60 & $R s=a+c_{1} T+c_{2} T^{2}+c_{3} T^{3}+c_{4} T^{4}+c_{5} T^{5}$ & $\mathrm{~T}$ & Dincer et al [158] \\
\hline Group 21 & T61 & $\begin{array}{l}\mathrm{Rs} / \mathrm{Ra}=\mathrm{a}+\mathrm{c}_{1} \triangle \mathrm{T}+\mathrm{c}_{2}(\triangle \mathrm{T})^{2}+\mathrm{c}_{3}(\triangle \mathrm{T})^{3}+\mathrm{c}_{4}(\triangle \mathrm{T})^{4}+\mathrm{c}_{5}(\triangle \\
\mathrm{T})^{5}+\mathrm{c}_{6}(\triangle \mathrm{T})^{6}+\mathrm{c}_{7}(\triangle \mathrm{T})^{7}+\mathrm{c}_{8}(\triangle \mathrm{T})^{8}+\mathrm{c}_{9}(\triangle \mathrm{T})^{9}+\mathrm{c}_{10}(\triangle \mathrm{T})^{10}\end{array}$ & Ra, Tmax, Tmin & Korachagaon and Bapat [53] \\
\hline Group 21 & T62 & $\begin{array}{l}\mathrm{Rs}=\mathrm{a}+\mathrm{c}_{1} \operatorname{Tmin}+\mathrm{c}_{2} \operatorname{T} \min ^{2}+\mathrm{c}_{3} \operatorname{Tmin}^{3}+\mathrm{c}_{4} \operatorname{Tmin}^{4}+\mathrm{c}_{5} \operatorname{Tmin}^{5}+ \\
\mathrm{c}_{6} \operatorname{Tmin}^{6}+\mathrm{c}_{7} \operatorname{Tmin}^{7}+\mathrm{c}_{8} \operatorname{Tmin}^{8}+\mathrm{c}_{9} \operatorname{Tmin}^{9}+\mathrm{c}_{10} \operatorname{Tmin}^{10}\end{array}$ & Tmin & Korachagaon and Bapat [53] \\
\hline Group 21 & T63 & $\begin{array}{l}\mathrm{Rs}=\mathrm{a}+\mathrm{c}_{1} \operatorname{Tmax}+\mathrm{c}_{2} \operatorname{Tmax}^{2}+\mathrm{c}_{3} \operatorname{Tmax}^{3}+\mathrm{c}_{4} \operatorname{Tmax}^{4}+\mathrm{c}_{5} \operatorname{Tmax}^{5} \\
+\mathrm{c}_{6} \operatorname{Tmax}^{6}+\mathrm{c}_{7} \operatorname{Tmax}^{7}+\mathrm{c}_{8} \operatorname{Tmax}^{8}+\mathrm{c}_{9} \operatorname{Tmax}^{9}+\mathrm{c}_{10} \operatorname{Tmax}^{10}\end{array}$ & $\operatorname{Tmax}$ & Korachagaon and Bapat [53] \\
\hline Group 21 & T64 & $\begin{array}{l}\mathrm{Rs}=\mathrm{a}+\mathrm{c}_{1} \operatorname{Tmax}+\mathrm{c}_{2} \triangle \mathrm{T}+\mathrm{c}_{3} \operatorname{Tmax}^{2}+\mathrm{c}_{4}(\triangle \mathrm{T})^{2}+\mathrm{c}_{5} \operatorname{Tmax}^{*} \triangle \\
\mathrm{T}+\mathrm{c}_{6} \operatorname{Tmax}^{3}+\mathrm{c}_{7}(\triangle \mathrm{T})^{3}+\mathrm{c}_{8} \operatorname{Tmax}^{*}(\triangle \mathrm{T})^{2}+\mathrm{c}_{9} \operatorname{Tmax}^{2} * \triangle \mathrm{T}\end{array}$ & Tmax, Tmin & Korachagaon and Bapat [53] \\
\hline Group 22 & TR1 & $\mathrm{Rs}=\mathrm{a}+\mathrm{c}_{1}(\mathrm{Rh}-\mathrm{T})$ & $\mathrm{T}, \mathrm{Rh}$ & Elagib et al [121] \\
\hline Group 22 & TR2 & $\mathrm{Rs} / \mathrm{Ra}=\mathrm{c}_{1}\left(1+\mathrm{d}_{1} \mathrm{Rh}\right) \triangle \mathrm{T}$ & Ra, Tmax, Tmin, Rh & Li et al [106] \\
\hline Group 22 & TR3 & $\mathrm{Rs}=\mathrm{a}+\mathrm{Ra}\left(\mathrm{c}_{1} \triangle \mathrm{T}+\mathrm{d}_{1} \mathrm{Rh}\right)$ & $\mathrm{Ra}$, Tmax, Tmin, Rh & Li et al [52] \\
\hline Group 22 & TR4 & $\mathrm{Rs} / \mathrm{Ra}=\mathrm{a}+\mathrm{c}_{1} \mathrm{Tmin} / \mathrm{Tmax} * \mathrm{Rh}$ & Ra, Tmax, Tmin, Rh & Adaramola [59] \\
\hline Group 22 & TR5 & $\mathrm{Rs} / \mathrm{Ra}=\mathrm{a}+\mathrm{c}_{1} \mathrm{~T}+\mathrm{d}_{1} \mathrm{Rh}$ & $\mathrm{T}, \mathrm{Rh}$ & El-Sebaii et al [159] \\
\hline Group 22 & TR6 & $\mathrm{Rs} / \mathrm{Ra}=\mathrm{a}+\mathrm{c}_{1}(\triangle \mathrm{T})^{0.5}+\mathrm{d}_{1} \mathrm{Rh}$ & Ra, Tmax, Tmin, Rh & Chen and $\mathrm{Li}[20]$ \\
\hline Group 22 & TR7 & $\mathrm{Rs} / \mathrm{Ra}=\mathrm{a}+\mathrm{c}_{1} \mathrm{Tmin} / \mathrm{Tmax}+\mathrm{d}_{1} \mathrm{Rh}$ & Ra, Tmax, Tmin, Rh & Richardson and Reddy [109] \\
\hline Group 22 & TR8 & $\mathrm{Rs}=\mathrm{a}+\mathrm{c}_{1}(\mathrm{Rh}-\triangle \mathrm{T}-\mathrm{Ra})$ & Ra, Tmax, Tmin, Rh & Elagib et al [121] \\
\hline Group 22 & TR9 & $\mathrm{Rs}=\mathrm{a}+\mathrm{c}_{1}(\mathrm{Rh}-\mathrm{T}-\mathrm{Ra})$ & $\mathrm{Ra}, \mathrm{T}, \mathrm{Rh}$ & Elagib et al [121] \\
\hline
\end{tabular}




\begin{tabular}{|c|c|c|c|c|}
\hline Group 22 & TR10 & $\mathrm{Rs} / \mathrm{Ra}=\mathrm{c}_{1}\left(1+\mathrm{d}_{1} \mathrm{Rh}\right)\left(1-\exp \left(\mathrm{c}_{2}(\triangle \mathrm{T})^{\mathrm{c} 3}\right)\right)$ & Ra, Tmax, Tmin, Rh & Li et al [106] \\
\hline Group 22 & TR11 & $R s=a+R a\left(c_{1} T \max +c_{2} T \min +d_{1} R h\right)$ & $\mathrm{Ra}$, Tmax, Tmin, Rh & Li et al [52] \\
\hline Group 22 & TR12 & $\mathrm{Rs}=\mathrm{a}+\mathrm{Ra}\left(\mathrm{c}_{1} \mathrm{Tmax}+\mathrm{c}_{2} \mathrm{Tmin}\right)+\mathrm{d}_{1} \mathrm{Rh}$ & Ra, Tmax, Tmin, Rh & Li et al [52] \\
\hline Group 22 & TR13 & $\mathrm{Rs} / \mathrm{Ra}=\mathrm{a}+\mathrm{c}_{1} \mathrm{Tmax}+\mathrm{c}_{2} \triangle \mathrm{T}+\mathrm{d}_{1} \mathrm{Rh}$ & Ra, Tmax, Tmin, Rh & Iranna and Bapat [53] \\
\hline Group 22 & TR14 & $\mathrm{Rs} / \mathrm{Ra}=\mathrm{a}+\mathrm{c}_{1} \triangle \mathrm{T}+\mathrm{c}_{2} \mathrm{Tmin} / \mathrm{Tmax}+\mathrm{d}_{1} \mathrm{Rh}$ & Ra, Tmax, Tmin, Rh & Kolebaje et al [58] \\
\hline Group 22 & TR15 & $\mathrm{Rs} / \mathrm{Ra}=\mathrm{a}+\mathrm{c}_{1} \mathrm{~T}+\mathrm{c}_{2} \mathrm{Tmin} / \mathrm{Tmax}+\mathrm{d}_{1} \mathrm{Rh}$ & $\mathrm{Ra}, \mathrm{Tmax}, \mathrm{Tmin}, \mathrm{T}, \mathrm{Rh}$ & Falayi et al [85] \\
\hline Group 22 & TR16 & $\mathrm{Rs} / \mathrm{Ra}=\mathrm{a}+\mathrm{c}_{1} \mathrm{Tmax}+\mathrm{c}_{2} \mathrm{Tmin}+\mathrm{c}_{3} \triangle \mathrm{T}+\mathrm{d}_{1} \mathrm{Rh}$ & Ra, Tmax, Tmin, Rh & Iranna and Bapat [53] \\
\hline Group 22 & TR17 & $\mathrm{Rs} / \mathrm{Ra}=\mathrm{a}+\mathrm{c}_{1} \mathrm{Tmax}+\mathrm{c}_{2} \operatorname{Tmax}^{2}+\mathrm{d}_{1} \mathrm{Rh}+\mathrm{c}_{3} \mathrm{Rh} * \mathrm{Tmax}+\mathrm{d}_{2} \mathrm{Rh}^{2}$ & $\mathrm{Ra}, \mathrm{Tmax}, \mathrm{Rh}$ & Ododo [160] \\
\hline Group 22 & TR18 & $\begin{array}{l}\mathrm{Rs}=\mathrm{a}+\mathrm{c}_{1} \operatorname{Tmax}+\mathrm{c}_{2} \operatorname{Tmax}^{2}+\mathrm{c}_{3} \operatorname{Tmax}^{3}+\mathrm{c}_{4} \operatorname{Tmax}^{4}+\mathrm{c}_{5} \operatorname{Tmax}^{5} \\
+\mathrm{d}_{1} \mathrm{Rh}+\mathrm{d}_{2} \mathrm{Rh}^{2}+\mathrm{d}_{3} \mathrm{Rh}^{3}+\mathrm{d}_{4} R \mathrm{Rh}^{4}+\mathrm{d}_{5} \mathrm{Rh}^{5}\end{array}$ & $\mathrm{Ra}, \mathrm{Tmax}, \mathrm{Rh}$ & Iranna and Bapat [53] \\
\hline Group 22 & TR19 & $\begin{array}{l}\mathrm{Rs}=\mathrm{a}+\mathrm{c}_{1} \ln \triangle \mathrm{T}+\mathrm{d}_{1} \mathrm{Rh}+\mathrm{c}_{2} \ln (\triangle \mathrm{T})^{2}+\mathrm{d}_{2} \mathrm{Rh}^{2}+\mathrm{c}_{3} \ln (\triangle \\
\mathrm{T})^{*} \mathrm{Rh}+\mathrm{c}_{4} \ln (\triangle \mathrm{T})^{3}+\mathrm{d}_{3} \mathrm{Rh}^{3}+\mathrm{c}_{5}(\ln \triangle \mathrm{T})(\mathrm{Rh})^{2}+\mathrm{c}_{6} \ln (\triangle \mathrm{T})^{2} * \mathrm{Rh}\end{array}$ & Tmax, Tmin, Rh & Iranna and Bapat [53] \\
\hline Group 23 & $\mathrm{TP} 1$ & $\mathrm{Rs} / \mathrm{Ra}=\mathrm{a}+\mathrm{c}_{1}(\triangle \mathrm{T})^{0.5}+\mathrm{e}_{1} \mathrm{P}$ & $\mathrm{Ra}, \mathrm{Tmax}, \mathrm{Tmin}, \mathrm{P}$ & Chen and $\mathrm{Li}[20]$ \\
\hline Group 23 & $\mathrm{TP} 2$ & $\mathrm{Rs} / \mathrm{Ra}=\mathrm{a}_{1}(\triangle \mathrm{T})^{\mathrm{cl}}\left(1+\mathrm{e}_{1} \mathrm{P}+\mathrm{e}_{2} \mathrm{P}^{2}\right)$ & Ra, Tmax, Tmin, $\mathrm{P}$ & De Jong and Stewart [161] \\
\hline Group 23 & TP3 & $\mathrm{Rs} / \mathrm{Ra}=\mathrm{a}+\mathrm{c}_{1} \mathrm{Tmax}+\mathrm{c}_{2} \mathrm{Tmin}+\mathrm{e}_{1} \mathrm{P}$ & $\mathrm{Ra}$, Tmax, Tmin, $\mathrm{P}$ & Li et al [104] \\
\hline Group 23 & TP4 & $\begin{array}{l}\mathrm{Rs} / \mathrm{Ra}=\mathrm{a}+\mathrm{c}_{1}(\triangle \mathrm{T})^{0.5}+\mathrm{c}_{2} \mathrm{~T}+\mathrm{e}_{1} \mathrm{~Pa} \\
\mathrm{P}>0, \mathrm{~Pa}=1 ; \mathrm{P}=0, \mathrm{~Pa}=0\end{array}$ & $\mathrm{Ra}, \mathrm{Tmax}, \mathrm{Tmin}, \mathrm{T}, \mathrm{P}$ & Wu et al [162] \\
\hline Group 23 & TP5 & $\mathrm{Rs}=\mathrm{a}+\mathrm{c}_{1} \operatorname{Ra}(\triangle \mathrm{T})^{0.5}+\mathrm{c}_{2} \mathrm{Tmax}+\mathrm{e}_{1} \mathrm{P}+\mathrm{e}_{2} \mathrm{P}^{2}$ & Ra, Tmax, Tmin, T, P & Hunt et al [142] \\
\hline Group 23 & TP6 & $\mathrm{Rs} / \mathrm{Ra}=\mathrm{a}+\mathrm{c}_{1} \mathrm{~T}+\mathrm{c}_{2} \mathrm{~T}^{2}+\mathrm{c}_{3} \mathrm{~T}^{3}+\mathrm{e}_{1} \mathrm{P}+\mathrm{e}_{1} \mathrm{P}^{2}$ & $\mathrm{Ra}, \mathrm{T}, \mathrm{P}$ & Chen et al [99] \\
\hline Group 23 & TP7 & $\begin{array}{l}\mathrm{Rs} / \mathrm{Ra}=\left(\mathrm{a}_{1}+\mathrm{c}_{1} \triangle \mathrm{T}+\mathrm{c}_{2}(\triangle \mathrm{T})^{0.25}+\mathrm{c}_{3}(\triangle \mathrm{T})^{0.5}\right)\left(1+\mathrm{c}_{4} \mathrm{~T}+\right. \\
\left.\mathrm{e}_{1} \mathrm{f}(\mathrm{p})\right), \mathrm{f}(\mathrm{p})=\ln (\mathrm{P}+1)\end{array}$ & Ra, Tmax, Tmin, T, P & Fan et al [56] \\
\hline Group 24 & TPr1 & $\mathrm{Rs} / \mathrm{Ra}=\mathrm{c}_{1}(\triangle \mathrm{T})^{0.5}(\mathrm{Ap} / \mathrm{Aps})^{0.5}$ & Ra, Tmax, Tmin, Ap & Allen [163] \\
\hline Group 24 & $\operatorname{TPr} 2$ & $\mathrm{Rs} / \mathrm{Ra}=\mathrm{a}+\mathrm{c}_{1}(\triangle \mathrm{T})^{0.5}+\mathrm{f}_{1} \mathrm{Ap}$ & Ra, Tmax, Tmin, Ap & Chen and $\mathrm{Li}[20]$ \\
\hline Group 24 & TPr3 & $\mathrm{Rs} / \mathrm{Ra}=\mathrm{a}+\mathrm{c}_{1}(\triangle \mathrm{T})^{0.5}+\mathrm{c}_{2} \mathrm{D}$ & $\mathrm{Ra}, \mathrm{Tmax}, \mathrm{Tmin}, \mathrm{T}, \mathrm{Vp}$ & Chen et al [54] \\
\hline Group 24 & $\mathrm{TPr} 4$ & $\mathrm{Rs}=\mathrm{a}+\mathrm{a}_{1} \mathrm{Ra}+\mathrm{c}_{1}(\triangle \mathrm{T})^{0.5}+\mathrm{c}_{2} \mathrm{D}$ & Ra, Tmax, Tmin, T, Vp & Chen et al [54] \\
\hline
\end{tabular}




\begin{tabular}{|c|c|c|c|c|}
\hline Group 24 & TPr5 & $\mathrm{Rs}=\mathrm{a}+\mathrm{Ra}\left(\mathrm{a}_{1}+\mathrm{c}_{1}(\triangle \mathrm{T})^{0.5}\right)+\mathrm{c}_{2} \log (\mathrm{D})$ & $\mathrm{Ra}, \mathrm{Tmax}, \mathrm{Tmin}, \mathrm{T}, \mathrm{Vp}$ & Chen et al [54] \\
\hline Group 24 & TPr6 & $\mathrm{Rs}=\mathrm{a}+\mathrm{Ra}\left(\mathrm{a}_{1}+\mathrm{c}_{1}(\triangle \mathrm{T})^{0.5}\right)+\mathrm{c}_{2} \mathrm{D}$ & Ra, Tmax, Tmin, T, Vp & Chen et al [54] \\
\hline Group 25 & TG1 & $\mathrm{Rs} / \mathrm{Ra}=\mathrm{c}_{1}\left(1+2.7^{*} 10^{-5} \mathrm{Z}\right)(\triangle \mathrm{T})^{0.5}$ & Ra, Tmax, Tmin, Z & Annandale et al [164] \\
\hline Group 25 & TG2 & $\mathrm{Rs} / \mathrm{Ra}=\mathrm{a}+\mathrm{c}_{1} \mathrm{Tmin} / \mathrm{Tmax}+\mathrm{g}_{1} \delta$ & Ra, Tmax, Tmin, $\delta$ & Akpabio et al [61] \\
\hline Group 25 & TG3 & $\begin{array}{l}\mathrm{Rs}=\left(\mathrm{c}_{1}(\triangle \mathrm{T})^{\mathrm{c} 2}(\mathrm{~L})^{\mathrm{c} 3}-\mathrm{c}_{4}\right) / \mathrm{c}_{5} \\
\mathrm{~L}=0.8+0.12((182-\mathrm{n}) / 183)^{1.5}\end{array}$ & Tmax, Tmin, $\mathrm{n}$ & Mahmood and Hubbard [165] \\
\hline Group 25 & TG4 & $\mathrm{Rs} / \mathrm{Ra}=\mathrm{a}_{1}\left(1+\mathrm{g}_{1} \cos \left(\mathrm{g}_{2} \mathrm{n} \pi / 180+\mathrm{a}_{2}\right)\right)\left(1-\exp \left(\mathrm{c}_{1}(\triangle \mathrm{T})^{\mathrm{c} 2}\right)\right)$ & Tmax, Tmin, $\mathrm{n}$ & Li et al [106] \\
\hline Group 26 & TRP1 & $R s=a+R a\left(a_{1}+c_{1} T+d_{1} R h+e_{1} P\right)$ & $\mathrm{Ra}, \mathrm{T}, \mathrm{Rh}, \mathrm{P}$ & Chen et al [54] \\
\hline Group 26 & TRP2 & $R s=a+R a\left(a_{1}+d_{1} R h\right)+c_{1} T+e_{1} P$ & $\mathrm{Ra}, \mathrm{T}, \mathrm{Rh}, \mathrm{P}$ & Chen et al [54] \\
\hline Group 26 & TRP3 & $R s=a+R a\left(a_{1}+d_{1} R h\right)+c_{1} \exp (T)+e_{1} P$ & $\mathrm{Ra}, \mathrm{T}, \mathrm{Rh}, \mathrm{P}$ & Chen et al [54] \\
\hline Group 26 & TRP4 & $\mathrm{Rs}=\mathrm{Ra}\left(\mathrm{a}_{1}+(\triangle \mathrm{T})^{\mathrm{cl}}\right)\left(1+\mathrm{d}_{1} \mathrm{Rh}\right)+\mathrm{e}_{1} \mathrm{~Pa}$ & Ra, Tmax, Tmin, Rh, P & Quej et al [108] \\
\hline Group 26 & TRP5 & $\begin{array}{l}\mathrm{Rs}=\operatorname{Ra}\left(\mathrm{a}_{1}+\mathrm{c}_{1} \triangle \mathrm{T}+\mathrm{c}_{2}(\triangle \mathrm{T})^{0.25}+\mathrm{c}_{3}(\triangle \mathrm{T})^{0.5}\right)\left(1+\mathrm{c}_{4} \mathrm{~T}+\right. \\
\left.\mathrm{e}_{1} \mathrm{f}(\mathrm{p})\right)+\mathrm{d}_{1} \mathrm{Rh}\end{array}$ & Ra, Tmax, Tmin, T, Rh, P & Fan et al [56] \\
\hline Group 27 & TRPr1 & $\mathrm{Rs} / \mathrm{Ra}=\mathrm{a}+\mathrm{c}_{1}(\triangle \mathrm{T})^{0.5}+\mathrm{d}_{1} \mathrm{Rh}+\mathrm{f}_{1} \mathrm{Ap}$ & Ra, Tmax, Tmin, Rh, Ap & Chen and $\mathrm{Li}[20]$ \\
\hline Group 27 & TRPr2 & $\mathrm{Rs} / \mathrm{Ra}=\mathrm{a}+\mathrm{c}_{1}(\triangle \mathrm{T})^{0.5}+\mathrm{d}_{1} \mathrm{Rh}+\mathrm{f}_{1} \mathrm{Vp}$ & Ra, Tmax, Tmin, Rh, Vp & Chen and $\mathrm{Li}$ [25] \\
\hline Group 27 & TRPr3 & $\mathrm{Rs} / \mathrm{Ra}=\mathrm{a}+\mathrm{c}_{1} \mathrm{Tmax}+\mathrm{c}_{2} \mathrm{Tmin}+\mathrm{d}_{1} \mathrm{Rh}+\mathrm{f}_{1} \mathrm{Ap}$ & $\mathrm{Ra}$, Tmax, Tmin, Rh, Ap & Chen and Li [20] \\
\hline Group 27 & TRPr4 & $\begin{array}{l}\text { Rs/Ra }=a+c_{1} \operatorname{Tmax}+c_{2} \operatorname{Tmin}+c_{3} \operatorname{Tmin} * T \max +d_{1} R h+ \\
f_{1} A p\end{array}$ & Ra, Tmax, Tmin, Rh, Ap & Chen and Li [20] \\
\hline Group 28 & TRG1 & $\mathrm{Rs} / \mathrm{Ra}=\mathrm{a}+\mathrm{c}_{1} \mathrm{Wa} 2+\mathrm{g}_{1} \delta$ & $\mathrm{Ra}, \mathrm{T}, \mathrm{Rh}, \delta$ & Garg and Garg [133] \\
\hline Group 28 & TRG2 & $\mathrm{Rs}=\mathrm{a}+\mathrm{c}_{1} \operatorname{Tmin} / \mathrm{Tmax}+\mathrm{d}_{1} \mathrm{Rh}+\mathrm{g}_{1} \delta$ & Tmax, Tmin, Rh, $\delta$ & Akpabio et al [61] \\
\hline Group 28 & TRG3 & $\mathrm{Rs} / \mathrm{Ra}=\mathrm{a}_{1}\left(1+\mathrm{g}_{1} \cos \left(\mathrm{g}_{2} \mathrm{n} \pi / 180+\mathrm{a}_{2}\right)+\mathrm{d}_{1} \mathrm{Rh}\right) \triangle \mathrm{T}$ & Tmax, Tmin, Rh, $\mathrm{n}$ & Li et al [106] \\
\hline Group 28 & TRG4 & $\begin{array}{l}\mathrm{Rs} / \mathrm{Ra}=\mathrm{a}_{1}\left(1+\mathrm{g}_{1} \cos \left(\mathrm{g}_{2} \mathrm{n} \pi / 180+\mathrm{a}_{2}\right)+\mathrm{d}_{1} \mathrm{Rh}\right)\left(1-\exp \left(\mathrm{c}_{1}(\triangle\right.\right. \\
\left.\left.\mathrm{T})^{\mathrm{c} 2}\right)\right)\end{array}$ & Tmax, Tmin, Rh, n & Li et al [106] \\
\hline Group 29 & TPPr1 & $\mathrm{Rs} / \mathrm{Ra}=\mathrm{a}+\mathrm{c}_{1}(\triangle \mathrm{T})^{0.5}+\mathrm{e}_{1} \mathrm{P}+\mathrm{c}_{2} \mathrm{D}$ & Ra, Tmax, Tmin, T, P, Vp & Chen et al [54] \\
\hline Group 29 & TPPr2 & $\mathrm{Rs}=\mathrm{a}+\operatorname{Ra}\left(\mathrm{c}_{1}(\triangle \mathrm{T})^{0.5}+\mathrm{a}_{1}\right)+\mathrm{e}_{1} \mathrm{P}+\mathrm{c}_{2} \mathrm{D}$ & $\mathrm{Ra}, \mathrm{Tmax}, \mathrm{Tmin}, \mathrm{T}, \mathrm{P}, \mathrm{Vp}$ & Chen et al [54] \\
\hline
\end{tabular}




\begin{tabular}{|c|c|c|c|c|}
\hline Group 29 & TPPr3 & $\mathrm{Rs}=\mathrm{a}+\operatorname{Ra}\left(\left(\mathrm{c}_{1}(\triangle \mathrm{T})^{0.5}+\mathrm{a}_{1}\right)+\mathrm{a}_{2}\right)+\mathrm{e}_{1} \mathrm{P}+\mathrm{c}_{2} \mathrm{D}$ & Ra, Tmax, Tmin, T, P, Vp & Chen et al [54] \\
\hline Group 29 & TPPr4 & $\mathrm{Rs}=\mathrm{a}+\mathrm{Ra}\left(\mathrm{a}_{1}+\mathrm{c}_{1}(\triangle \mathrm{T})^{0.5}+\mathrm{e}_{1} \operatorname{Pr}\right)+\mathrm{c}_{2} \mathrm{~T}+\mathrm{c}_{3} \log (\mathrm{D})+\mathrm{e}_{2} \mathrm{P}$ & $\mathrm{Ra}, \mathrm{Tmax}, \mathrm{Tmin}, \mathrm{T}, \mathrm{P}, \mathrm{Vp}$ & Chen et al [54] \\
\hline Group 30 & TPW1 & $\mathrm{Rs}=\mathrm{a}+\mathrm{c}_{1} \mathrm{Tmax}+\mathrm{c}_{2} \mathrm{Tmin}+\mathrm{e}_{1} \mathrm{P}+\mathrm{h}_{1} \mathrm{Wv}$ & Tmax, Tmin, $\mathrm{P}, \mathrm{Wv}$ & Richardson and Reddy [1009] \\
\hline Group 31 & TPG1 & $\mathrm{Rs} / \mathrm{Ra}=\mathrm{a}+\mathrm{c}_{1} \mathrm{~T}+\mathrm{c}_{2} \mathrm{~T}^{2}+\mathrm{c}_{3} \mathrm{~T}^{3}+\mathrm{e}_{1} \mathrm{P}+\mathrm{e}_{2} \mathrm{P}^{2}+\mathrm{g}_{1} \varphi+\mathrm{g}_{2} \lambda+\mathrm{g}_{3} \mathrm{Z}$ & $\mathrm{Ra}, \mathrm{T}, \mathrm{P}, \varphi, \mathrm{Z}, \lambda$ & Chen et al [99] \\
\hline Group 31 & TPG2 & $\begin{array}{l}\mathrm{Rs}=\mathrm{a}+\mathrm{c}_{1} \operatorname{Tmax}+\mathrm{c}_{2} \operatorname{Tmax}^{2}+\mathrm{c}_{3} \operatorname{Tmin}+\mathrm{c}_{4} \operatorname{Tmin}^{2}+ \\
\mathrm{c}_{5} \operatorname{Tmax} * \operatorname{Tmin}+\mathrm{e}_{1} \mathrm{P}+\mathrm{e}_{2} \mathrm{P}^{2}+\mathrm{c}_{6} \operatorname{Tmax} * \mathrm{P}+\mathrm{c}_{7} \mathrm{Tmin} * \mathrm{P}+\mathrm{g}_{1} \mathrm{n}+ \\
\mathrm{c}_{8} \operatorname{Tmaxn}\end{array}$ & Tmax, Tmin, $\mathrm{P}, \mathrm{n}$ & Ball et al [166] \\
\hline Group 32 & TRPG1 & $\begin{array}{l}\mathrm{Rs} / \mathrm{Ra}=\left(\mathrm{a}+\mathrm{g}_{1} \sin \mathrm{M}+\mathrm{g}_{2} \cos \mathrm{M}+\mathrm{d}_{1} \mathrm{Rh}+\mathrm{e}_{1} \mathrm{~Pa}\right)\left(1-\exp \left(\mathrm{c}_{1}(\triangle\right.\right. \\
\left.\left.\mathrm{T})^{\mathrm{c}}\right)\right)\end{array}$ & $\mathrm{Ra}, \mathrm{Tmax}, \mathrm{Tmin}, \mathrm{Rh}, \mathrm{P}, \mathrm{n}$ & Meza and Yebra [110] \\
\hline Group 33 & $\mathrm{R} 1$ & $\mathrm{Rs}=\mathrm{d}_{1} \mathrm{Rh}^{\mathrm{d} 2}$ & $\mathrm{Rh}$ & Lewis [90] \\
\hline Group 33 & $\mathrm{R} 2$ & $\mathrm{Rs}=\mathrm{d}_{1} \exp \left(\mathrm{d}_{2} \mathrm{Rh}\right)$ & $\mathrm{Rh}$ & Lewis [90] \\
\hline Group 33 & $\mathrm{R} 3$ & $\mathrm{Rs}=\mathrm{a}+\mathrm{d}_{1} \mathrm{Rh}$ & $\mathrm{Rh}$ & Ertekin and Yaldiz [150] \\
\hline Group 33 & $\mathrm{R} 4$ & $\mathrm{Rs} / \mathrm{Ra}=\mathrm{a}+\mathrm{d}_{1} \mathrm{Rh}$ & $\mathrm{Ra}, \mathrm{Rh}$ & Mubiru et al [111] \\
\hline Group 33 & R5 & $\mathrm{Rs}=\mathrm{a}+\mathrm{d}_{1}(\mathrm{Rh}-\mathrm{Ra})$ & $\mathrm{Ra}, \mathrm{Rh}$ & Elagib et al [122] \\
\hline Group 33 & R6 & $\mathrm{Rs} / \mathrm{Ra}=\mathrm{a}+\mathrm{d}_{1} \mathrm{Rh}+\mathrm{d}_{2} \mathrm{Rh}^{\mathrm{d} 3}$ & $\mathrm{Ra}, \mathrm{Rh}$ & Kolebaje e al [58] \\
\hline Group 33 & R7 & $\begin{array}{l}\mathrm{Rs} / \mathrm{Ra}=\mathrm{a}+\mathrm{d}_{1} R \mathrm{Rh}+\mathrm{d}_{2} R h^{2}+\mathrm{d}_{3} R h^{3}+\mathrm{d}_{4} R h^{4}+\mathrm{d}_{5} R h^{5}+\mathrm{d}_{6} R h^{6}+ \\
\mathrm{d}_{7} R h^{7}+\mathrm{d}_{8} R h^{8}+\mathrm{d}_{9} R h^{9}+\mathrm{c}_{10} R h^{10}\end{array}$ & $\mathrm{Ra}, \mathrm{Rh}$ & Iranna and Bapat [53] \\
\hline Group 34 & $\mathrm{P} 1$ & $\mathrm{Rs} / \mathrm{Ra}=\mathrm{a}+\mathrm{e}_{1} \mathrm{P}$ & $\mathrm{Ra}, \mathrm{P}$ & Adaramola [59] \\
\hline Group 35 & RP1 & $\mathrm{Rs}=\mathrm{a}+\mathrm{a}_{1} \mathrm{Ra}+\mathrm{d}_{1} \mathrm{Rh}+\mathrm{e}_{1} \mathrm{P}$ & $\mathrm{Ra}, \mathrm{P}, \mathrm{Rh}$ & Akpabio et al [61] \\
\hline Group 36 & PG1 & $\mathrm{Rs} / \mathrm{Ra}=\mathrm{a}+\mathrm{e}_{1} \mathrm{P}^{0.33}+\mathrm{g}_{1} \varphi$ & $\mathrm{Ra}, \mathrm{P}, \varphi$ & Reddy [112] \\
\hline Group 37 & Pr1 & $\mathrm{Rs}=\mathrm{a}+\mathrm{a}_{1} \mathrm{Ra}+\mathrm{e}_{1} \mathrm{Ap}$ & $\mathrm{Ra}, \mathrm{Ap}$ & Kamal [60] \\
\hline
\end{tabular}


Table 2 RMSE $\left(\mathrm{MJ} \mathrm{m}^{-2}\right.$ ) and RRMSE of the empirical models for solar radiation estimation

\begin{tabular}{|c|c|c|c|c|c|c|c|}
\hline \multirow{2}{*}{$\begin{array}{l}\text { Model } \\
\text { group }\end{array}$} & \multirow{2}{*}{$\begin{array}{l}\text { Model } \\
\text { ID }\end{array}$} & \multicolumn{2}{|c|}{ Chongqing } & \multicolumn{2}{|c|}{ Wanzhou } & \multicolumn{2}{|c|}{ Yichang } \\
\hline & & RMSE & RRMSE & RMSE & RRMSE & RMSE & RRMSE \\
\hline Group 3 & SR1 & 1.533 & $17.16 \%$ & 1.242 & $13.55 \%$ & 2.684 & $25.43 \%$ \\
\hline Group 3 & SR2 & 1.823 & $20.41 \%$ & 1.610 & $17.58 \%$ & 3.257 & $30.86 \%$ \\
\hline Group 3 & SR3 & 3.186 & $35.66 \%$ & 2.859 & $31.21 \%$ & 3.899 & $36.94 \%$ \\
\hline Group 3 & SR4 & 1.816 & $20.33 \%$ & 1.581 & $17.25 \%$ & 3.287 & $31.15 \%$ \\
\hline Group 3 & SR5 & 1.094 & $12.25 \%$ & 0.808 & $8.81 \%$ & 1.602 & $15.18 \%$ \\
\hline Group 3 & SR6 & 1.164 & $13.03 \%$ & 0.953 & $10.40 \%$ & 1.380 & $13.08 \%$ \\
\hline Group 3 & SR7 & 1.089 & $12.19 \%$ & 0.800 & $8.73 \%$ & 1.597 & $15.14 \%$ \\
\hline Group 3 & SR8 & 1.088 & $12.18 \%$ & 0.800 & $8.73 \%$ & 1.599 & $15.15 \%$ \\
\hline Group 4 & SP1 & 1.079 & $12.08 \%$ & 0.801 & $8.74 \%$ & 1.550 & $14.69 \%$ \\
\hline Group 5 & SPr1 & 1.049 & $11.75 \%$ & 0.798 & $8.71 \%$ & 1.488 & $14.10 \%$ \\
\hline Group 5 & SPr2 & 1.233 & $13.81 \%$ & 1.076 & $11.75 \%$ & 1.870 & $17.72 \%$ \\
\hline Group 5 & SPr3 & 1.039 & $11.63 \%$ & 0.785 & $8.57 \%$ & 1.502 & $14.24 \%$ \\
\hline Group 9 & STPr1 & 0.950 & $10.64 \%$ & 0.805 & $8.79 \%$ & 1.347 & $12.77 \%$ \\
\hline Group 9 & STPr2 & 0.965 & $10.81 \%$ & 0.807 & $8.81 \%$ & 1.255 & $11.89 \%$ \\
\hline Group 9 & STPr3 & 1.008 & $11.28 \%$ & 0.791 & $8.63 \%$ & 1.386 & $13.13 \%$ \\
\hline Group 10 & SRP1 & 1.151 & $12.89 \%$ & 0.956 & $10.43 \%$ & 1.359 & $12.87 \%$ \\
\hline Group 11 & STG1 & 1.053 & $11.79 \%$ & 0.905 & $9.88 \%$ & 1.284 & $12.17 \%$ \\
\hline Group 11 & STG2 & 1.045 & $11.70 \%$ & 0.905 & $9.88 \%$ & 1.272 & $12.05 \%$ \\
\hline Group 12 & STRP1 & 0.964 & $10.79 \%$ & 0.809 & $8.84 \%$ & 1.249 & $11.84 \%$ \\
\hline Group 12 & STRP2 & 1.013 & $11.34 \%$ & 0.806 & $8.80 \%$ & 1.364 & $12.92 \%$ \\
\hline Group 13 & STRPr1 & 0.972 & $10.88 \%$ & 0.812 & $8.86 \%$ & 1.356 & $12.84 \%$ \\
\hline Group 13 & STRPr2 & 0.930 & $10.42 \%$ & 0.812 & $8.86 \%$ & 1.252 & $11.86 \%$ \\
\hline Group 13 & STRPr3 & 0.969 & $10.85 \%$ & 0.810 & $8.84 \%$ & 1.362 & $12.90 \%$ \\
\hline Group 13 & STRPr4 & 0.911 & $10.20 \%$ & 0.788 & $8.61 \%$ & 1.246 & $11.80 \%$ \\
\hline Group 14 & STPPr1 & 1.006 & $11.26 \%$ & 0.788 & $8.60 \%$ & 1.381 & $13.09 \%$ \\
\hline Group 15 & STRW1 & 0.930 & $10.41 \%$ & 0.808 & $8.82 \%$ & 1.234 & $11.69 \%$ \\
\hline Group 17 & STPG1 & 1.027 & $11.50 \%$ & 0.849 & $9.27 \%$ & 1.381 & $13.09 \%$ \\
\hline Group 17 & STPG2 & 0.999 & $11.18 \%$ & 0.842 & $9.19 \%$ & 1.379 & $13.07 \%$ \\
\hline Group 17 & STPG3 & 0.977 & $10.94 \%$ & 0.842 & $9.19 \%$ & 1.379 & $13.07 \%$ \\
\hline Group 17 & STPG4 & 0.963 & $10.78 \%$ & 0.839 & $9.16 \%$ & 1.377 & $13.05 \%$ \\
\hline
\end{tabular}


Table 2 RMSE $\left(\mathrm{MJ} \mathrm{m}^{-2}\right.$ ) and RRMSE of the empirical models for solar radiation estimation (continued)

\begin{tabular}{|c|c|c|c|c|c|c|c|}
\hline \multirow{2}{*}{$\begin{array}{l}\text { Model } \\
\text { group }\end{array}$} & \multirow{2}{*}{$\begin{array}{l}\text { Model } \\
\text { ID }\end{array}$} & \multicolumn{2}{|c|}{ Chongqing } & \multicolumn{2}{|c|}{ Wanzhou } & \multicolumn{2}{|c|}{ Yichang } \\
\hline & & RMSE & RRMSE & RMSE & RRMSE & RMSE & RRMSE \\
\hline Group 17 & STPG5 & 1.010 & $11.30 \%$ & 0.843 & $9.20 \%$ & 1.345 & $12.74 \%$ \\
\hline Group 18 & STRPP1 & 1.024 & $11.46 \%$ & 0.760 & $8.29 \%$ & 1.378 & $13.06 \%$ \\
\hline Group 18 & STRPP2 & 1.023 & $11.45 \%$ & 0.741 & $8.09 \%$ & 1.200 & $11.37 \%$ \\
\hline Group 19 & STRPW1 & 0.930 & $10.41 \%$ & 0.811 & $8.86 \%$ & 1.248 & $11.83 \%$ \\
\hline Group 19 & STRPW2 & 0.906 & $10.14 \%$ & 0.803 & $8.77 \%$ & 1.255 & $11.89 \%$ \\
\hline Group 20 & STRPG1 & 0.928 & $10.39 \%$ & 0.915 & $9.99 \%$ & 1.231 & $11.66 \%$ \\
\hline Group 20 & STRPG2 & 0.873 & $9.77 \%$ & 0.810 & $8.84 \%$ & 1.228 & $11.64 \%$ \\
\hline Group 23 & TP1 & 1.531 & $17.14 \%$ & 1.514 & $16.53 \%$ & 1.519 & $14.40 \%$ \\
\hline Group 23 & TP2 & 1.515 & $16.96 \%$ & 1.505 & $16.42 \%$ & 1.543 & $14.62 \%$ \\
\hline Group 23 & TP3 & 1.363 & $15.26 \%$ & 1.387 & $15.14 \%$ & 1.419 & $13.44 \%$ \\
\hline Group 23 & TP4 & 1.392 & $15.58 \%$ & 1.411 & $15.40 \%$ & 1.416 & $13.42 \%$ \\
\hline Group 23 & TP5 & 1.447 & $16.20 \%$ & 1.479 & $16.15 \%$ & 1.423 & $13.48 \%$ \\
\hline Group 23 & TP6 & 1.490 & $16.68 \%$ & 1.489 & $16.25 \%$ & 1.593 & $15.09 \%$ \\
\hline Group 23 & TP7 & 1.216 & $13.62 \%$ & 1.317 & $14.37 \%$ & 1.363 & $12.91 \%$ \\
\hline Group 24 & TPr1 & 2.152 & $24.09 \%$ & 1.850 & $20.20 \%$ & 1.603 & $15.18 \%$ \\
\hline Group 24 & TPr2 & 1.567 & $17.54 \%$ & 1.508 & $16.46 \%$ & 1.540 & $14.60 \%$ \\
\hline Group 24 & TPr3 & 1.419 & $15.88 \%$ & 1.469 & $16.03 \%$ & 1.502 & $14.23 \%$ \\
\hline Group 24 & TPr4 & 1.538 & $17.22 \%$ & 1.738 & $18.97 \%$ & 1.551 & $14.69 \%$ \\
\hline Group 24 & TPr5 & 1.594 & $17.84 \%$ & 1.489 & $16.26 \%$ & 1.529 & $14.49 \%$ \\
\hline Group 24 & TPr6 & 1.463 & $16.38 \%$ & 1.523 & $16.62 \%$ & 1.509 & $14.29 \%$ \\
\hline Group 25 & TG1 & 1.631 & $18.26 \%$ & 1.561 & $17.03 \%$ & 1.562 & $14.80 \%$ \\
\hline Group 25 & TG2 & 2.413 & $27.01 \%$ & 2.223 & $24.26 \%$ & 1.862 & $17.64 \%$ \\
\hline Group 25 & TG3 & 1.294 & $14.48 \%$ & 1.321 & $14.42 \%$ & 1.327 & $12.57 \%$ \\
\hline Group 25 & TG4 & 1.089 & $12.19 \%$ & 1.216 & $13.27 \%$ & 1.264 & $11.97 \%$ \\
\hline Group 26 & TRP1 & 1.299 & $14.54 \%$ & 1.532 & $16.72 \%$ & 1.621 & $15.36 \%$ \\
\hline Group 26 & TRP2 & 1.390 & $15.57 \%$ & 1.666 & $18.18 \%$ & 1.634 & $15.48 \%$ \\
\hline Group 26 & TRP3 & 1.695 & $18.97 \%$ & 1.674 & $18.27 \%$ & 1.949 & $18.46 \%$ \\
\hline Group 26 & TRP4 & 1.463 & $16.38 \%$ & 1.604 & $17.50 \%$ & 1.495 & $14.17 \%$ \\
\hline Group 26 & TRP5 & 1.138 & $12.74 \%$ & 1.248 & $13.62 \%$ & 1.318 & $12.49 \%$ \\
\hline Group 27 & TRPr1 & 1.396 & $15.63 \%$ & 1.506 & $16.43 \%$ & 1.541 & $14.60 \%$ \\
\hline
\end{tabular}


Table 2 RMSE $\left(\mathrm{MJ} \mathrm{m}^{-2}\right.$ ) and RRMSE of the empirical models for solar radiation estimation (continued)

\begin{tabular}{cccccccc}
\hline Model & \multirow{2}{*}{ Model } & \multicolumn{2}{c}{ Chongqing } & \multicolumn{2}{c}{ Wanzhou } & \multicolumn{2}{c}{ Yichang } \\
group & ID & RMSE & RRMSE & RMSE & RRMSE & RMSE & RRMSE \\
\hline Group 27 & TRPr2 & 1.202 & $13.45 \%$ & 1.370 & $14.95 \%$ & 1.476 & $13.98 \%$ \\
Group 27 & TRPr3 & 1.244 & $13.93 \%$ & 1.387 & $15.14 \%$ & 1.448 & $13.72 \%$ \\
Group 27 & TRPr4 & 1.104 & $12.35 \%$ & 1.186 & $12.94 \%$ & 1.369 & $12.97 \%$ \\
Group 28 & TRG1 & 1.652 & $18.49 \%$ & 1.516 & $16.54 \%$ & 1.862 & $17.64 \%$ \\
Group 28 & TRG2 & 1.815 & $20.32 \%$ & 2.073 & $22.62 \%$ & 1.749 & $16.57 \%$ \\
Group 28 & TRG3 & 1.047 & $11.72 \%$ & 1.227 & $13.39 \%$ & 1.311 & $12.42 \%$ \\
Group 28 & TRG4 & 1.039 & $11.63 \%$ & 1.220 & $13.32 \%$ & 1.296 & $12.28 \%$ \\
Group 29 & TPPr1 & 1.365 & $15.29 \%$ & 1.508 & $16.46 \%$ & 1.501 & $14.22 \%$ \\
Group 29 & TPPr2 & 1.395 & $15.61 \%$ & 1.507 & $16.45 \%$ & 1.506 & $14.27 \%$ \\
Group 29 & TPPr3 & 1.179 & $13.19 \%$ & 1.363 & $14.88 \%$ & 1.323 & $12.53 \%$ \\
Group 29 & TPPr4 & 1.175 & $13.15 \%$ & 1.362 & $14.87 \%$ & 1.311 & $12.42 \%$ \\
Group 30 & TPW1 & 1.365 & $15.28 \%$ & 1.473 & $16.08 \%$ & 1.525 & $14.45 \%$ \\
Group 31 & TPG1 & 1.026 & $11.48 \%$ & 1.145 & $12.49 \%$ & 1.379 & $13.07 \%$ \\
Group 31 & TPG2 & 1.555 & $17.41 \%$ & 1.467 & $16.01 \%$ & 1.910 & $18.10 \%$ \\
Group 32 & TRPG1 & 1.046 & $11.71 \%$ & 1.243 & $13.57 \%$ & 1.285 & $12.17 \%$ \\
Group 33 & R1 & 3.607 & $40.38 \%$ & 3.878 & $42.33 \%$ & 3.923 & $37.17 \%$ \\
Group 33 & R2 & 3.589 & $40.18 \%$ & 3.854 & $42.06 \%$ & 3.923 & $37.17 \%$ \\
Group 33 & R3 & 3.591 & $40.20 \%$ & 3.749 & $40.92 \%$ & 3.923 & $37.17 \%$ \\
Group 33 & R4 & 2.084 & $23.33 \%$ & 2.324 & $25.36 \%$ & 2.058 & $19.50 \%$ \\
Group 33 & R5 & 2.167 & $24.26 \%$ & 2.298 & $25.08 \%$ & 2.139 & $20.27 \%$ \\
Group 33 & R6 & 2.074 & $23.22 \%$ & 2.298 & $25.08 \%$ & 2.061 & $19.52 \%$ \\
Group 33 & R7 & 2.075 & $23.23 \%$ & 2.302 & $25.12 \%$ & 2.035 & $19.28 \%$ \\
Group 34 & P1 & 3.254 & $36.43 \%$ & 2.290 & $24.99 \%$ & 2.001 & $18.96 \%$ \\
Group 35 & RP1 & 1.917 & $21.47 \%$ & 2.139 & $23.35 \%$ & 1.799 & $17.04 \%$ \\
Group 36 & PG1 & 3.174 & $35.54 \%$ & 2.416 & $26.37 \%$ & 2.105 & $19.94 \%$ \\
Group 37 & Pr1 & 2.299 & $25.74 \%$ & 1.755 & $19.16 \%$ & 1.994 & $18.89 \%$ \\
\hline & & & & & & &
\end{tabular}


Table 3 RMSE $\left(\mathrm{MJ} \mathrm{m}^{-2}\right.$ ) and RRMSE of the top three empirical models in each group

\begin{tabular}{|c|c|c|c|c|c|c|c|}
\hline $\begin{array}{l}\text { Model } \\
\text { group }\end{array}$ & $\begin{array}{c}\text { Model } \\
\text { ID } \\
\end{array}$ & RMSE & RRMSE & $\begin{array}{l}\text { Model } \\
\text { group }\end{array}$ & $\begin{array}{c}\text { Model } \\
\text { ID } \\
\end{array}$ & RMSE & RRMSE \\
\hline Group 1 & S15 & 1.1005 & $11.45 \%$ & Group 12 & STRP2 & 1.0608 & $11.02 \%$ \\
\hline Group 1 & S16 & 1.1464 & $11.96 \%$ & Group 13 & STRPr4 & 0.9818 & $10.20 \%$ \\
\hline Group 1 & S27 & 1.1559 & $11.96 \%$ & Grou & STRPr2 & 0.9980 & $10.38 \%$ \\
\hline Group 2 & ST10 & 0.9934 & $10.31 \%$ & Group 13 & STRPr1 & 1.0462 & $10.86 \%$ \\
\hline Group 2 & ST9 & 1.0065 & $10.47 \%$ & Group 14 & STPPr1 & 1.0584 & $10.98 \%$ \\
\hline Group 2 & ST4 & 1.0257 & $10.65 \%$ & Group 15 & STRW1 & 0.9908 & $10.31 \%$ \\
\hline Group 3 & SR7 & 1.1621 & $12.02 \%$ & Group 16 & STRG7 & 1.0403 & $10.86 \%$ \\
\hline Group 3 & SR6 & 1.1658 & $12.17 \%$ & Group 16 & STRG6 & 1.0443 & $10.90 \%$ \\
\hline Group 3 & SR5 & 1.1677 & $12.08 \%$ & Group 16 & STRG9 & 1.0456 & $10.88 \%$ \\
\hline Group 4 & SP1 & 1.1434 & $11.84 \%$ & Group 17 & STPG4 & 1.0600 & $11.00 \%$ \\
\hline Group 5 & SPr1 & 1.1115 & $11.52 \%$ & Group 17 & STPG5 & 1.0657 & $11.08 \%$ \\
\hline Group 5 & SPr2 & 1.3931 & $14.42 \%$ & Group 17 & STPG3 & 1.0659 & $11.06 \%$ \\
\hline Group 5 & SPr3 & 1.1088 & $11.48 \%$ & Group 18 & STRPP1 & 1.0539 & $10.94 \%$ \\
\hline Group 6 & SG16 & 1.0727 & $11.14 \%$ & Group 18 & STRPP2 & 0.9878 & $10.30 \%$ \\
\hline Group 6 & SG6 & 1.0895 & $11.31 \%$ & Group 19 & STRPW1 & 0.9964 & $10.36 \%$ \\
\hline Group 6 & SG27 & & & & STRPW2 & & $10.27 \%$ \\
\hline Group 7 & STR15 & 0.9762 & & Group 20 & STRPG1 & 247 & $10.68 \%$ \\
\hline Group 7 & STR16 & 0.9832 & $10.23 \%$ & Group 20 & STRPG2 & 0.9701 & $10.08 \%$ \\
\hline Group 7 & STR8 & 0.9918 & $10.32 \%$ & Group 21 & T59 & 1.2202 & $12.74 \%$ \\
\hline Group 8 & STP10 & & & Group 21 & T54 & 1.2300 & $12.84 \%$ \\
\hline Group 8 & STP9 & & $10.03 \%$ & Group 21 & $\mathrm{~T} 52$ & 1.2387 & $12.95 \%$ \\
\hline Group 8 & STP5 & 0.9916 & $10.32 \%$ & Group 22 & TR11 & 1.2395 & $12.98 \%$ \\
\hline Grol & STPr1 & & & Group 22 & TR12 & 1.3398 & $14.07 \%$ \\
\hline Group 9 & STPr2 & 1.0093 & $10.50 \%$ & Group 22 & TR16 & 1.3654 & $14.33 \%$ \\
\hline Group 9 & STPr3 & 1.0616 & $11.02 \%$ & Group 23 & TP7 & 1.2985 & $13.63 \%$ \\
\hline Group 10 & SRP1 & 1.1552 & $12.06 \%$ & Group 23 & TP3 & 1.3897 & $14.61 \%$ \\
\hline Group 11 & STG1 & 1.0807 & $11.28 \%$ & Group 23 & $\mathrm{TP} 4$ & 1.4064 & $14.80 \%$ \\
\hline Group 11 & STG2 & 1.0738 & $11.21 \%$ & Group 24 & TPr3 & 1.4633 & $15.38 \%$ \\
\hline Group 12 & STRP1 & 1.0077 & $10.49 \%$ & Group 24 & TPr6 & 1.4982 & $15.76 \%$ \\
\hline
\end{tabular}


Table 3 RMSE $\left(\mathrm{MJ} \mathrm{m}^{-2}\right.$ ) and RRMSE of the top three empirical models in each group (continued)

\begin{tabular}{cccccccc}
\hline $\begin{array}{c}\text { Model } \\
\text { group }\end{array}$ & $\begin{array}{c}\text { Model } \\
\text { ID }\end{array}$ & RMSE & RRMSE & $\begin{array}{c}\text { Model } \\
\text { group }\end{array}$ & $\begin{array}{c}\text { Model } \\
\text { ID }\end{array}$ & RMSE & RRMSE \\
\hline Group 24 & TPr5 & 1.5375 & $16.20 \%$ & Group 29 & TPPr3 & 1.2880 & $13.53 \%$ \\
Group 25 & TG4 & 1.1896 & $12.48 \%$ & Group 29 & TPPr1 & 1.4581 & $15.32 \%$ \\
Group 25 & TG3 & 1.3138 & $13.82 \%$ & Group 30 & TPW1 & 1.4542 & $15.27 \%$ \\
Group 25 & TG1 & 1.5844 & $16.70 \%$ & Group 31 & TPG1 & 1.1831 & $12.35 \%$ \\
Group 26 & TRP5 & 1.2346 & $12.95 \%$ & Group 31 & TPG2 & 1.6440 & $17.17 \%$ \\
Group 26 & TRP1 & 1.4840 & $15.54 \%$ & Group 32 & TRPG1 & 1.1914 & $12.48 \%$ \\
Group 26 & TRP4 & 1.5208 & $16.02 \%$ & Group 33 & R7 & 2.1370 & $22.54 \%$ \\
Group 27 & TRPr4 & 1.2194 & $12.76 \%$ & Group 33 & R6 & 2.1442 & $22.61 \%$ \\
Group 27 & TRPr2 & 1.3492 & $14.13 \%$ & Group 33 & R4 & 2.1553 & $22.73 \%$ \\
Group 27 & TRPr3 & 1.3597 & $14.26 \%$ & Group 34 & P1 & 2.5150 & $26.79 \%$ \\
Group 28 & TRG4 & 1.1850 & $12.41 \%$ & Group 35 & RP1 & 1.9518 & $20.62 \%$ \\
Group 28 & TRG3 & 1.1947 & $12.51 \%$ & Group 36 & PG1 & 2.5649 & $27.28 \%$ \\
Group 28 & TRG1 & 1.6765 & $17.56 \%$ & Group 37 & Pr1 & 2.0160 & $21.26 \%$ \\
Group 29 & TPPr4 & 1.2825 & $13.48 \%$ & & & & \\
\hline
\end{tabular}




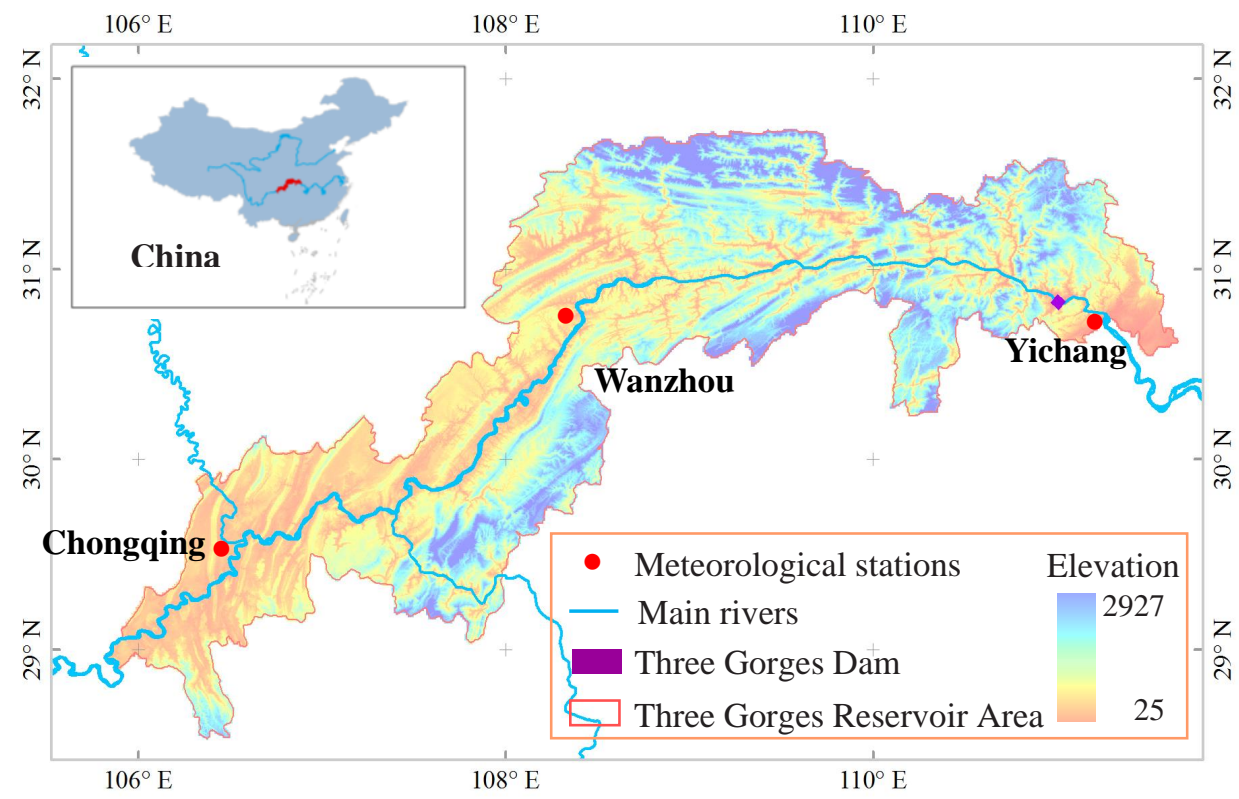

Fig.1 Location of Three Gorges Reservoir Area and theree studied meteorological sites 

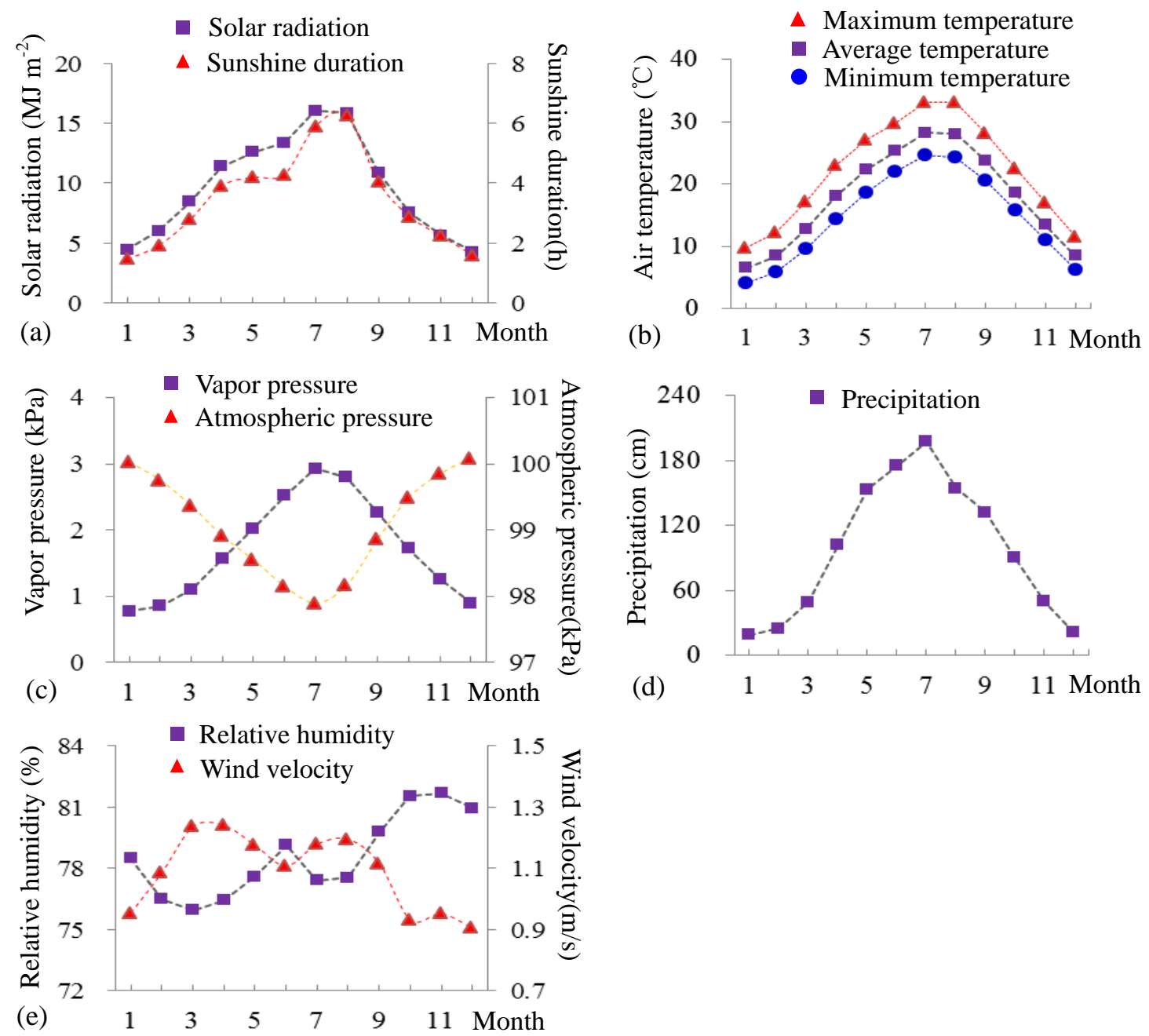

Fig.2 Temporal variations of the meteorological variables in Three Gorges Reservoir Area 

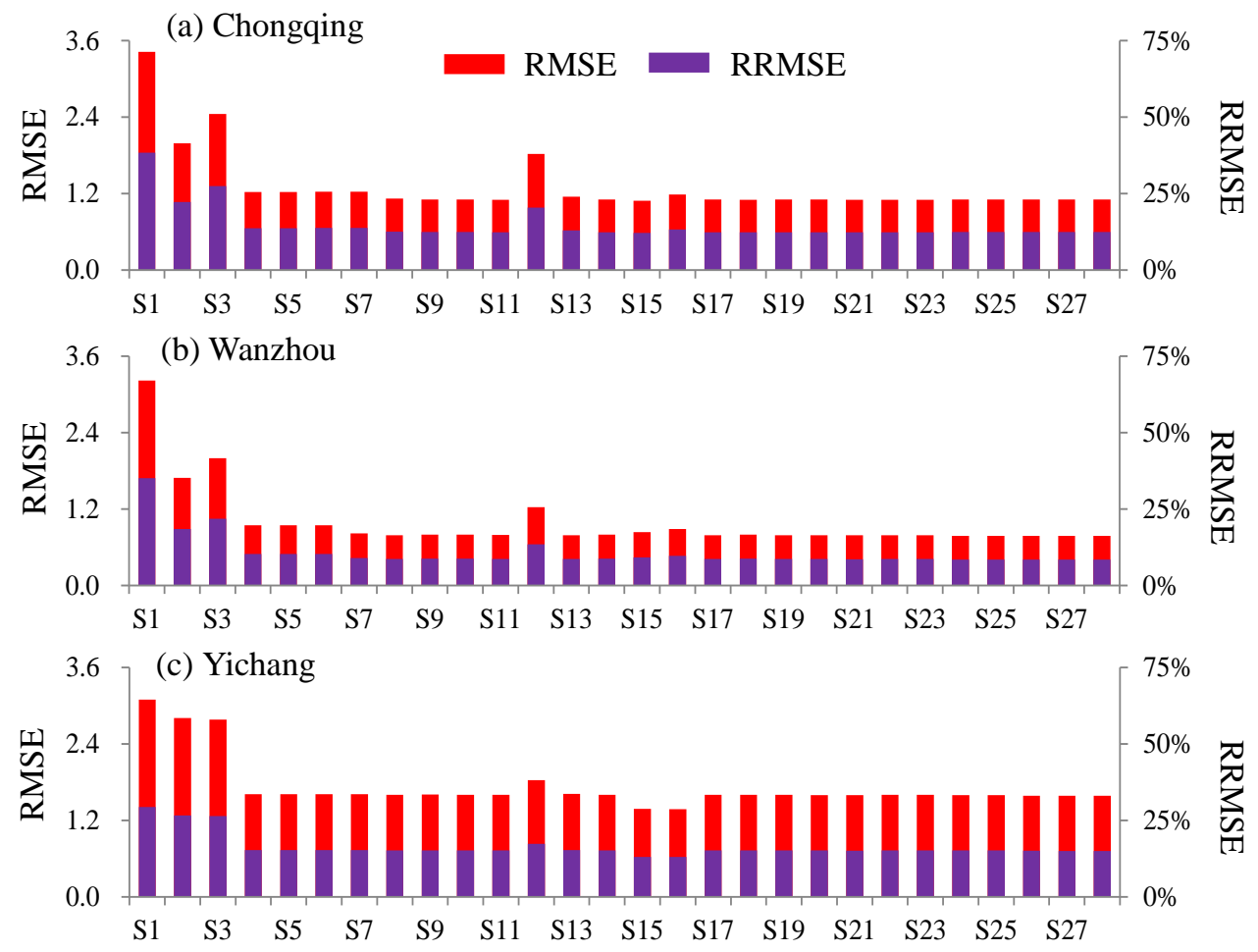

Fig.3 RMSE (MJ m ${ }^{-2}$ ) and RRMSE of the sunshine duration (S) models 

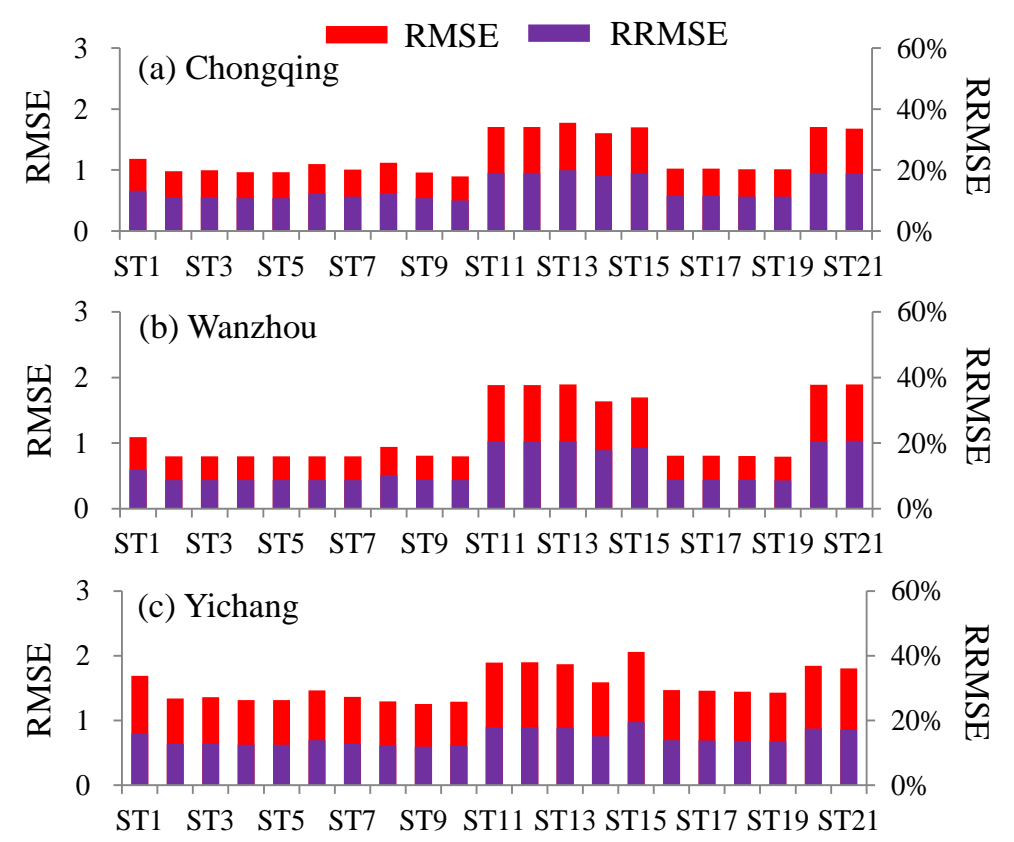

Fig.4 RMSE (MJ m ${ }^{-2}$ ) and RRMSE of the sunshine duration - temperature (ST) models 

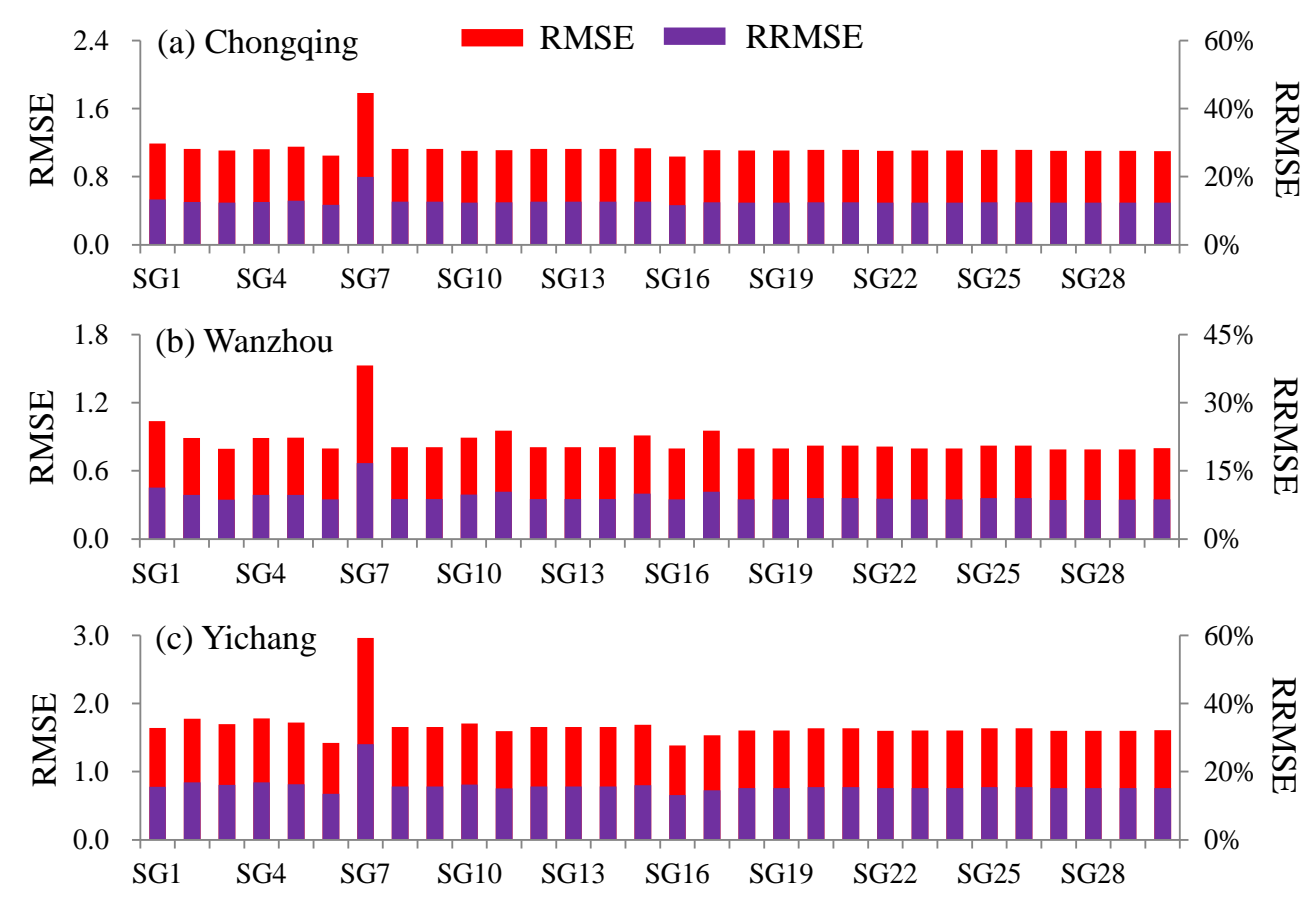

Fig.5 RMSE (MJ m ${ }^{-2}$ ) and RRMSE of the sunshine duration - geographic factors (SG) models 

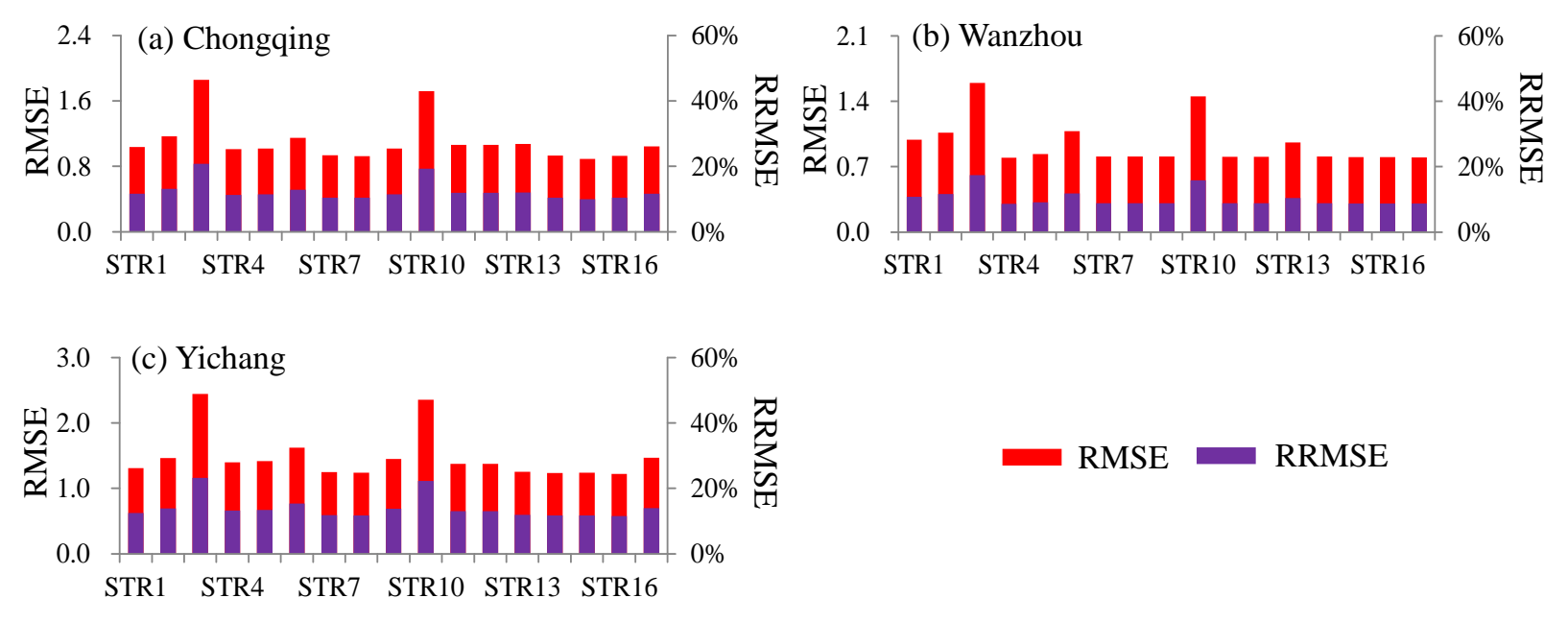

Fig.6 RMSE $\left(\mathrm{MJ} \mathrm{m}^{-2}\right)$ and RRMSE of the sunshine duration - temperature - relative humidity (STR) models 

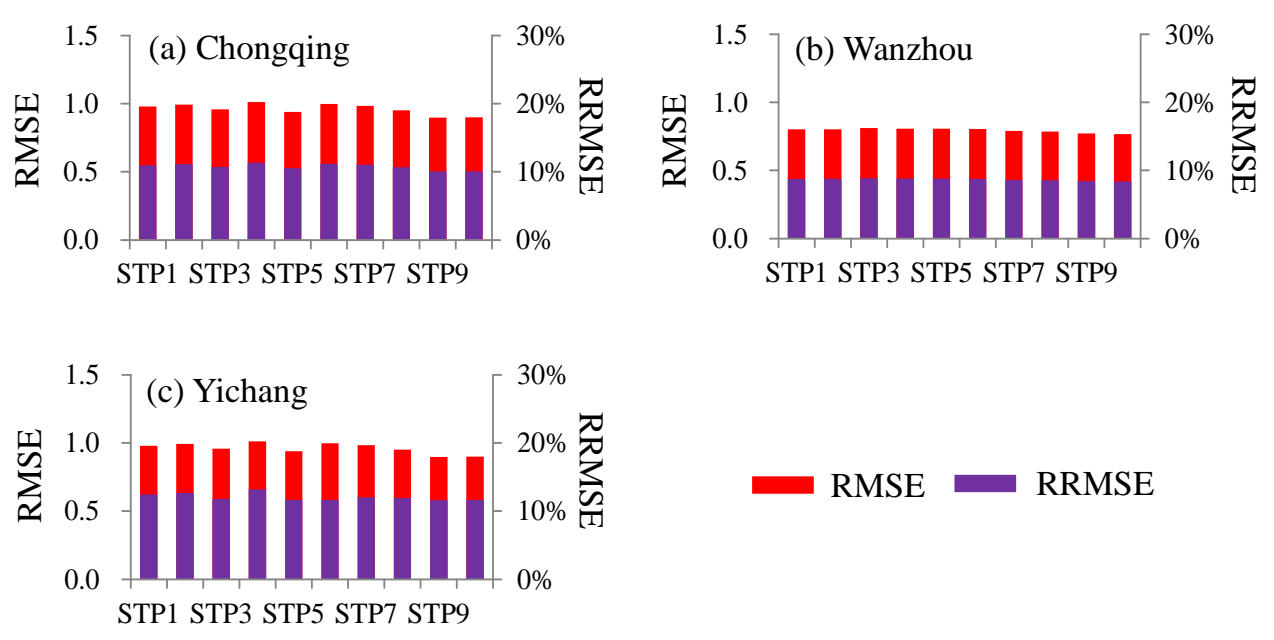

Fig.7 RMSE $\left(\mathrm{MJ} \mathrm{m}^{-2}\right)$ and RRMSE of the sunshine duration - temperature - precipitation (STP) models 

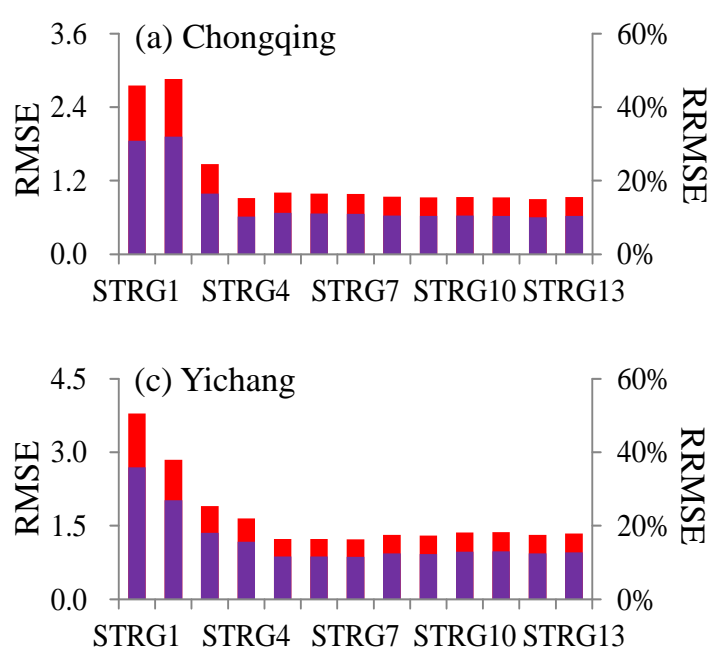

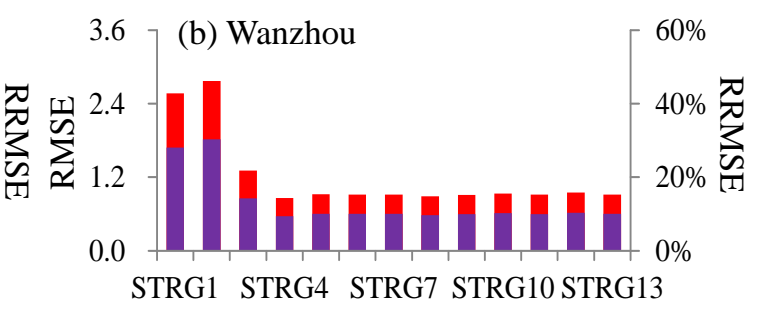

RMSE RRMSE

Fig.8 RMSE (MJ m${ }^{-2}$ ) and RRMSE of the sunshine duration - temperature - relative humidity geographic factors (STRG) models 

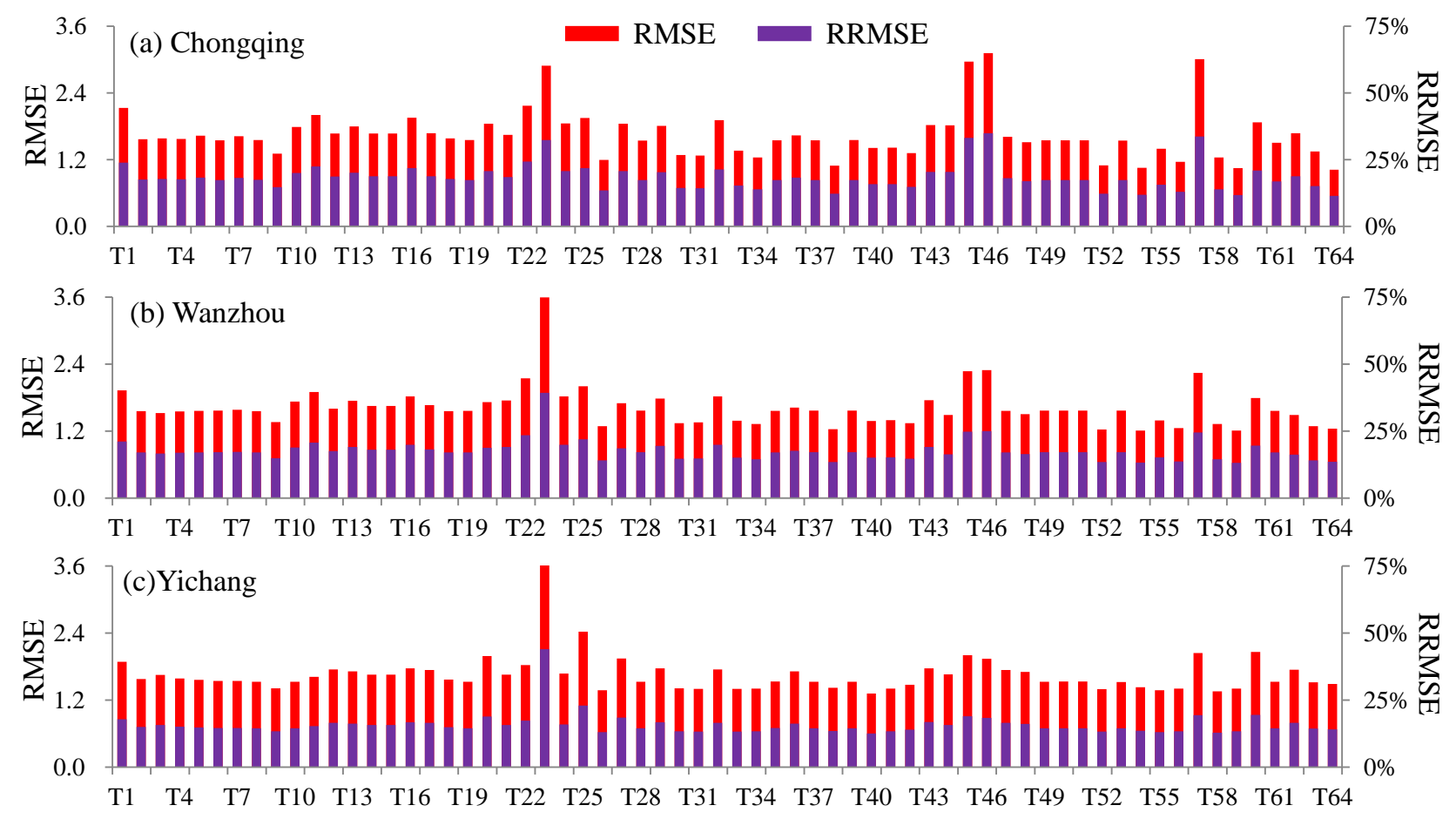

Fig.9 RMSE (MJ m${ }^{-2}$ ) and RRMSE of the temperature (T) models 

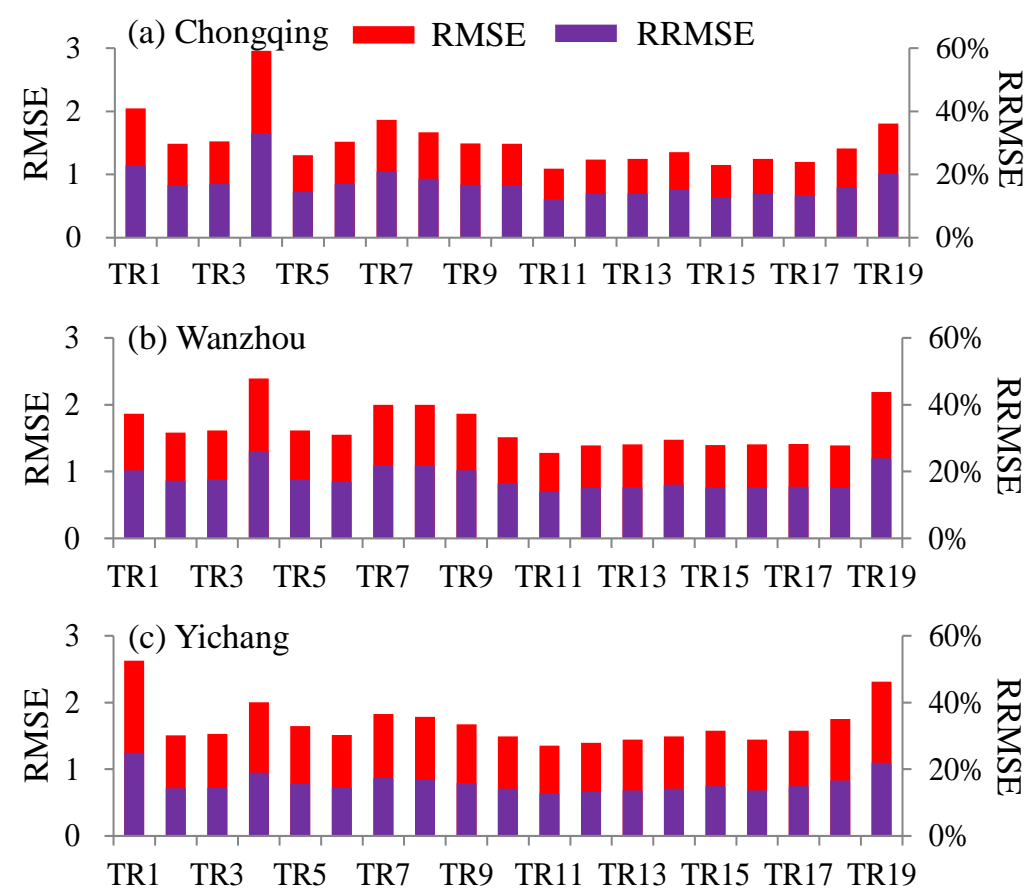

Fig.10 RMSE $\left(\mathrm{MJ} \mathrm{m}^{-2}\right.$ ) and RRMSE of the temperature - relative humidity (TR) models 